\title{
إثبات نسب اللقيط عن طريق البصمة الوراثية "دراسة فقهية مقارنة بالقانون الكويتي "نيق
}

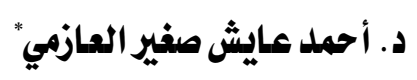

\section{المقدمة}

الحمد لله رب العـالمين، وأفضل الصلاة وأكمل التسليم على سيدنا محمد

$$
\text { وعلى آله وصحبه أجمعين وبعد: }
$$

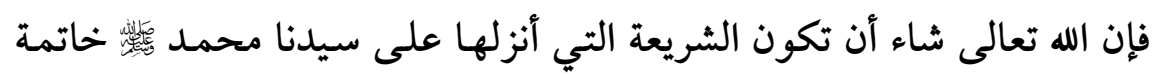

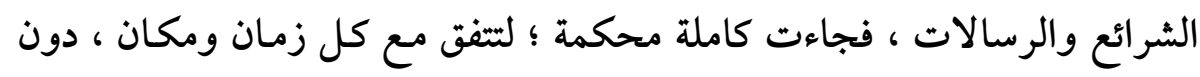

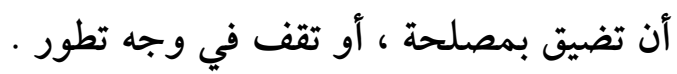

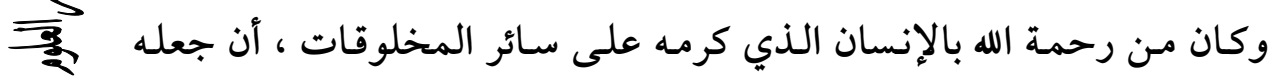

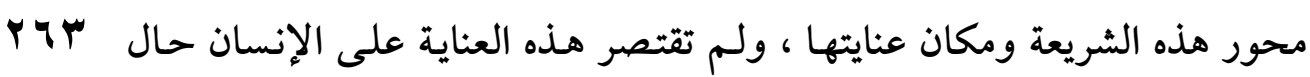

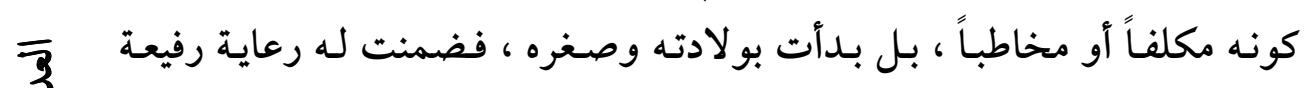

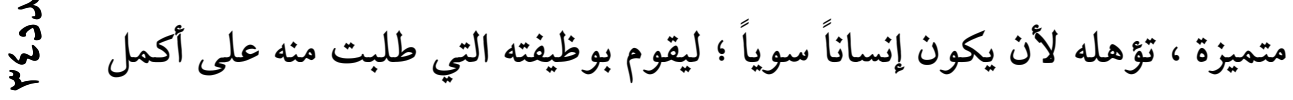

وجه.

هذا بالنسبة للطفل الذي تكون ظروفه عادية طبيعية ، أما الطفل الذي وجد في

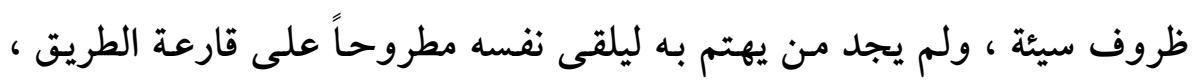

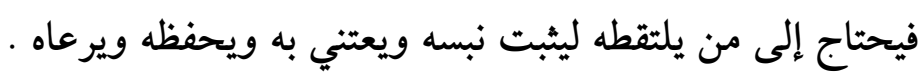

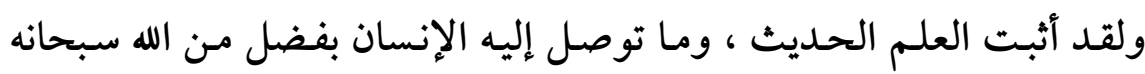

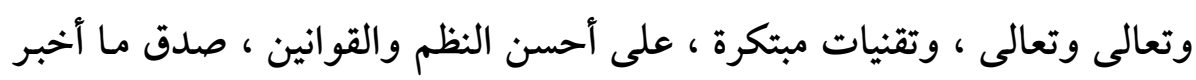

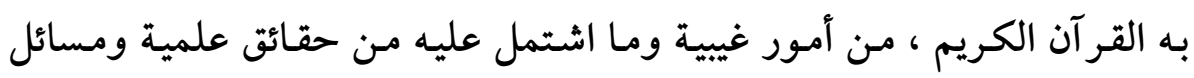

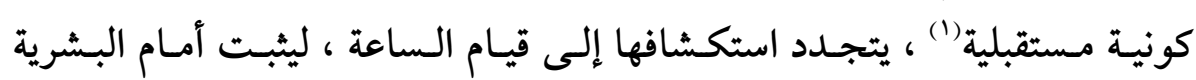


جمعاء أن القر آن الكريم هو حجة الله الخالدة إلى يوم الدين ، ولذا قال سبحانه

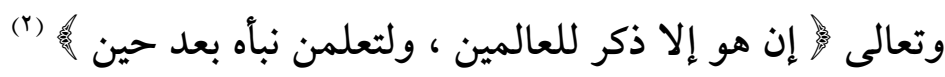

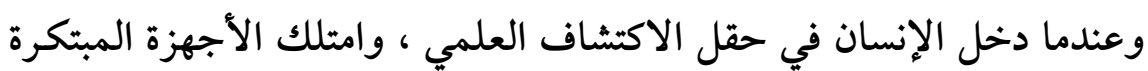

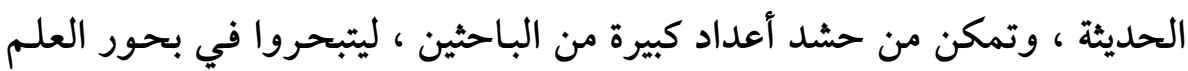

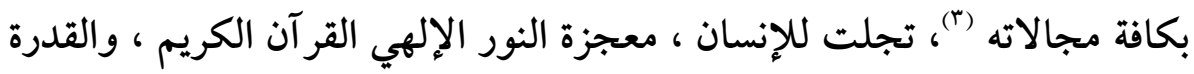

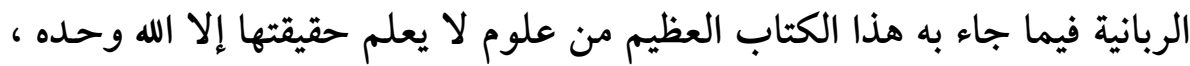

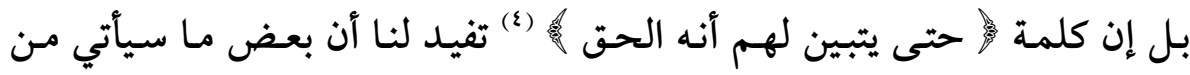

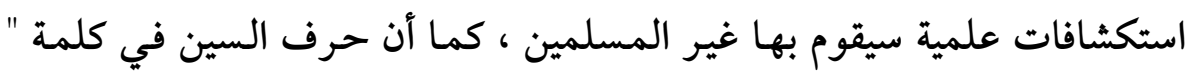

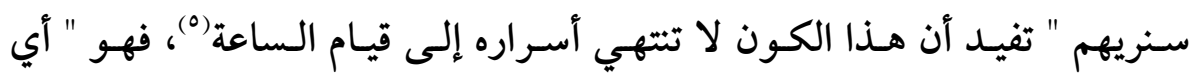

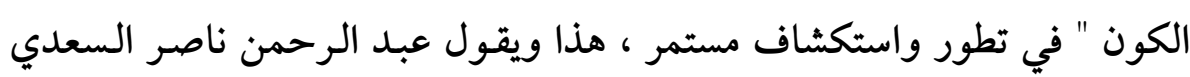

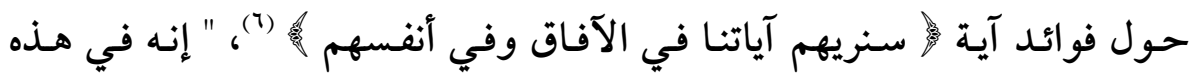

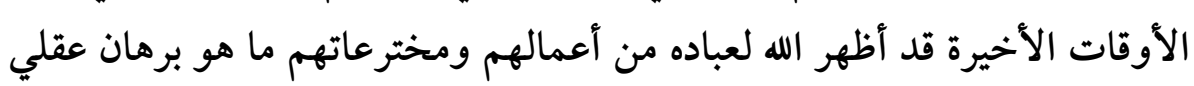

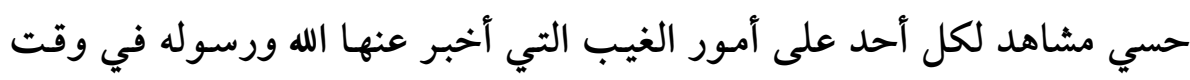

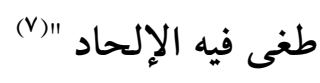

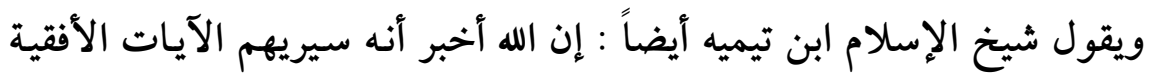

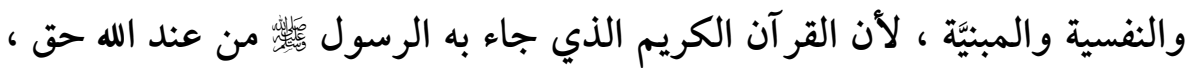

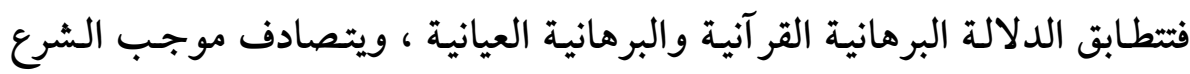

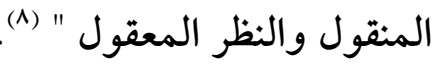
وهـذا البحـث يسلط الضوء على اللقيط وإثبـات نسبه عـن طريق البصمة

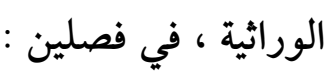

الفصل الأول : البصمة الوراثية ، تعريفها ، خصائصها ، مراحلها ، وفيه :

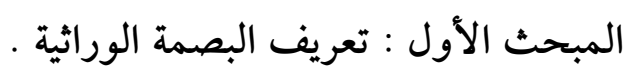

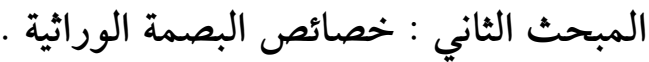

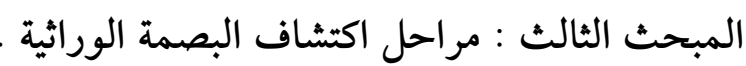

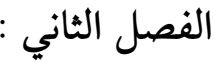


ضوابط وشـروط العمل بالبصمة الوراثية في إثبات نسب اللقيط في الفقه

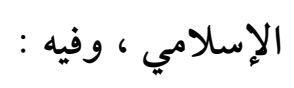

المبحث الأول : شروط العمل بالبصمة الوراثية وضوابطها

المبحث الثاني : تعريف اللقيط وحكم التقاطه .

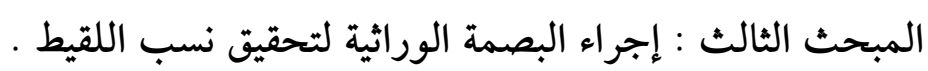

المبحث الرابع : موقف القضاء الكويتي من البصمة الوراثية .

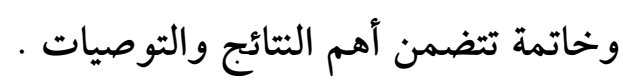

\section{الفمل الأول}

\section{البصمة الوراثية، تعريفها، خصائصها، مراحلها}

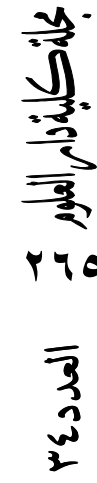

\section{المبحثالأول : تعريف البصمة الوراثية وملى مصداقيتها}

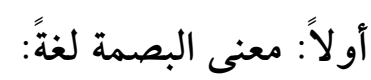

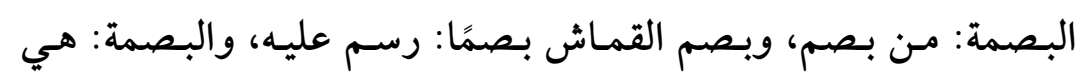

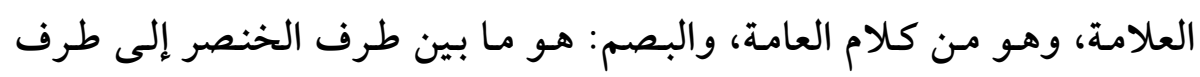

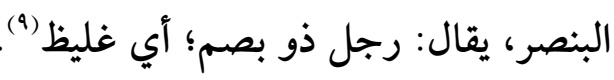

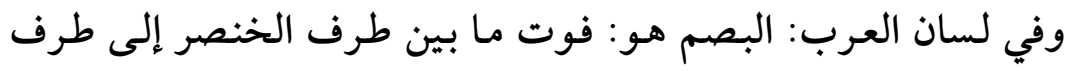

$$
\text { البنصر، والفوت هو : ما بين كل إصبعين طولًا (•) }
$$

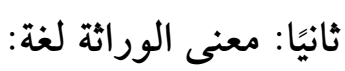

الوراثة من مصدر ورث أو أرث، ويقال: فعلان المال ومنه وعنه ورثًاً وإرثًا؛ أي صار إليه بعد موته، وفي الحديث: (الا يرث المسلم الكافر)، وأورث فيلانًا:

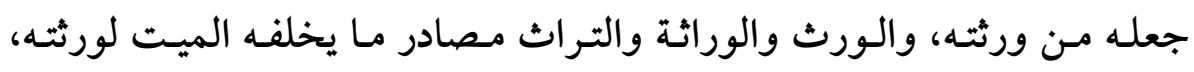

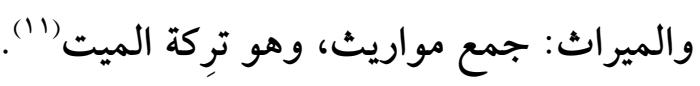

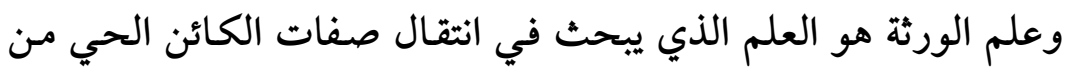

جيل إلى آخر، وتفسير الظاهرة المتعلقة بطريقة هذا الانتقال (r)". ثالثًا: المعنى الاصطلاحي للبصمة الوراثية: 
اجتهــد العلمـاء المعاصـرون في وضـع تعريـف مناسـب للبـصمة الوراثيـة

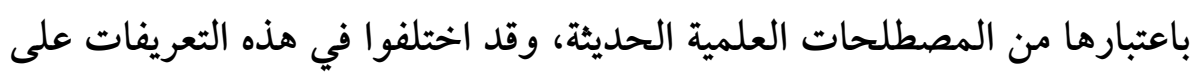

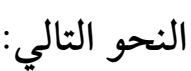

1- تعريف ندوة الوراثة والهندسة الوراثية والجينوم البشري للمنظمة الإسلامية

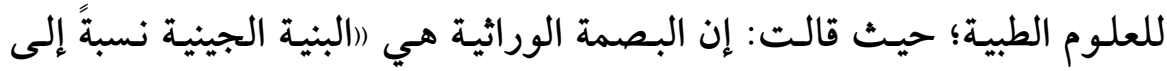

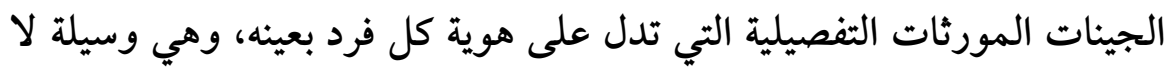

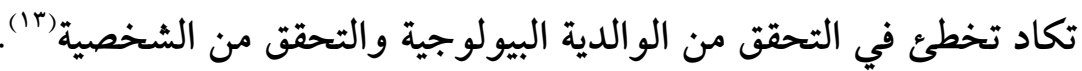

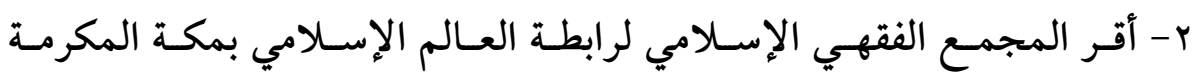

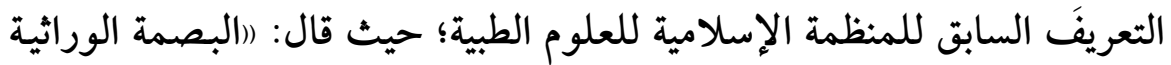

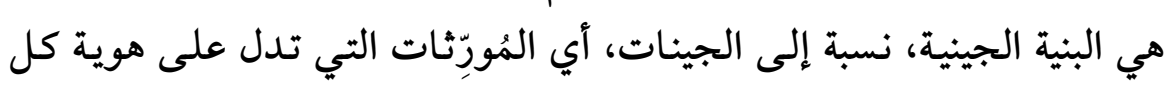

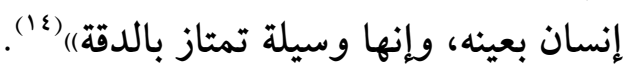

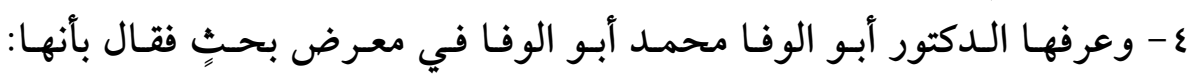

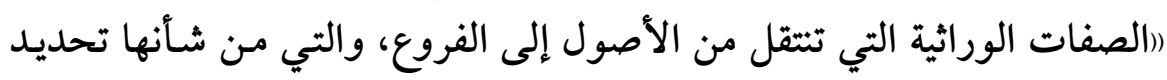

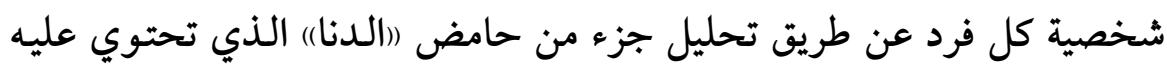

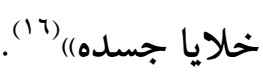

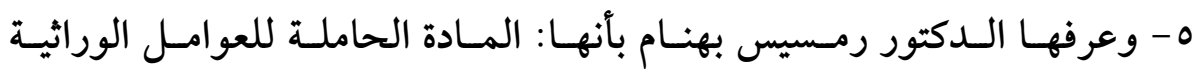

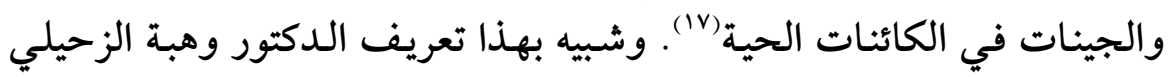

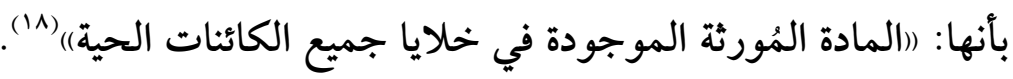

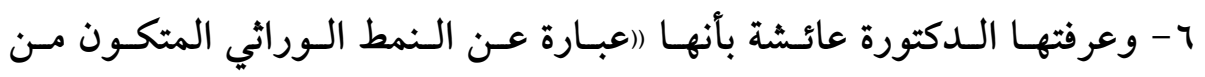

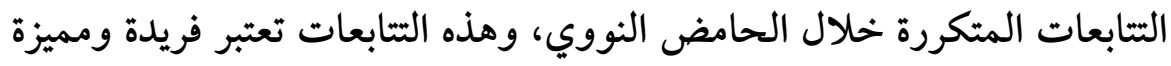
لكل شخص") (19) 


\section{اثيـات نسب اللقيط عنطريق البصمة الوراثية}

V - وعرفها الدكتور عبد الله عبد الغني غانم بأنها: (اصورة لتركيب المادة الحاملة

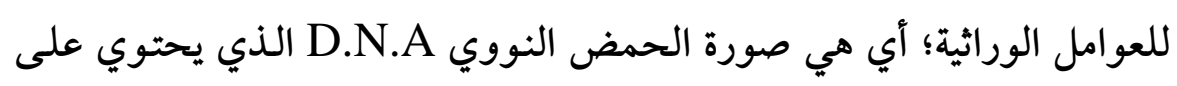

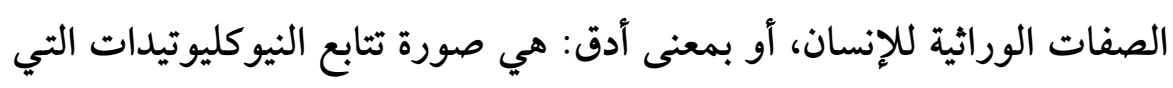

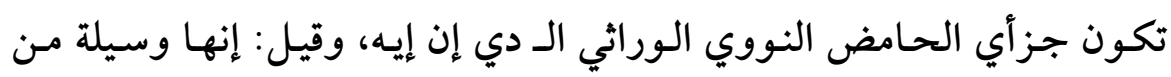

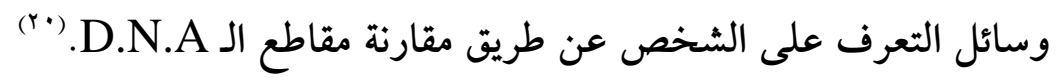

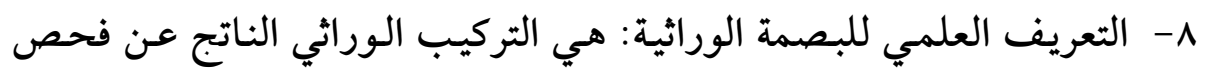

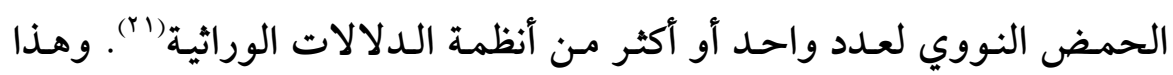

$$
\text { التعريف الأخير هو أنسب تعاريف البصمة الوراثية. }
$$

مناقشة وتعقيب: والناظر لهذه التعريفات سواء تعريفي (المنظمة الإسلامية))

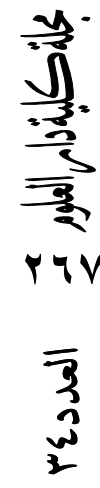

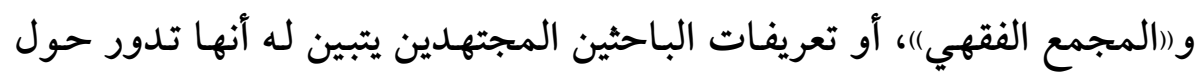

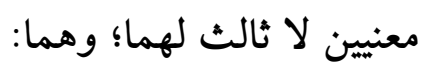
المعنى الأول: انتقال الصفات الوراثية من الآباء إلى الأبناء.

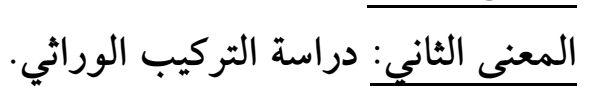
وسنتناول فيما يأتي أهم الأعمال التي تقوم بها البصمة الورائية التئ.

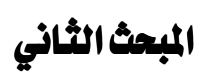 \\ خصائص البصمة الوراثية}

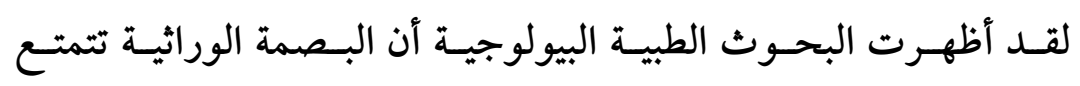

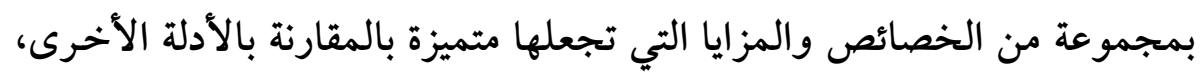

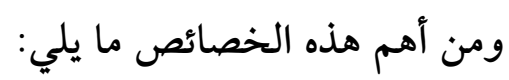

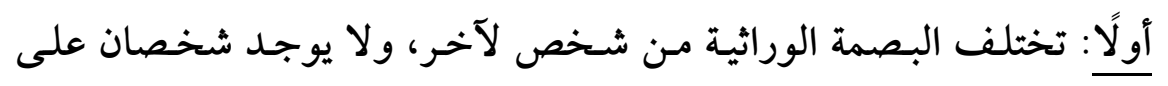

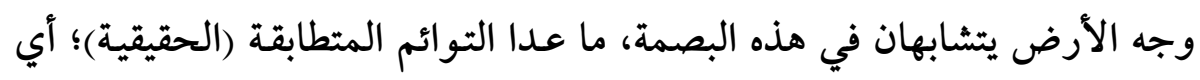

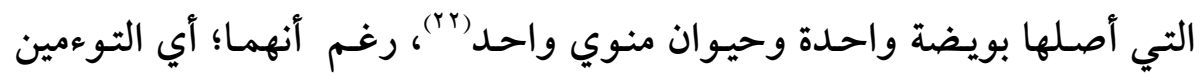

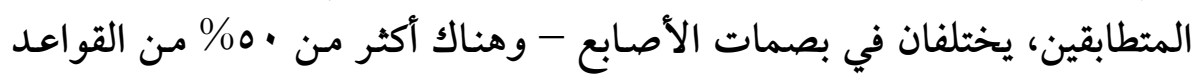

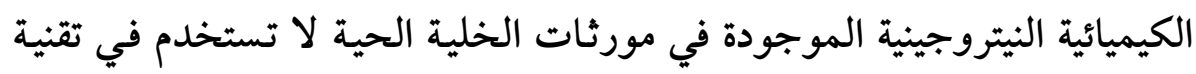

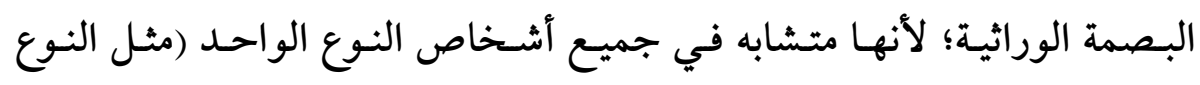


الإنساني) ... أما الكمية المتبقية من هذه القواعد وما تحتويه من أحماض الدنا (D.N.A)

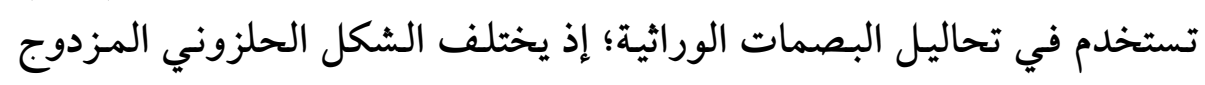

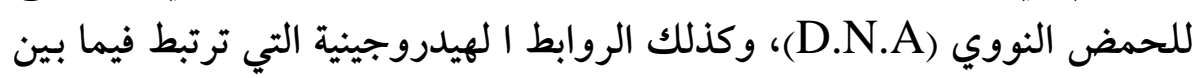

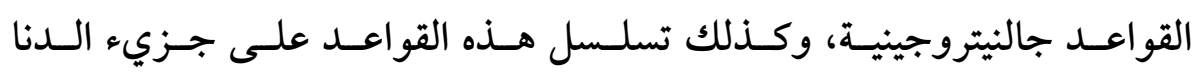
من شخص لآخر (D.N.A)

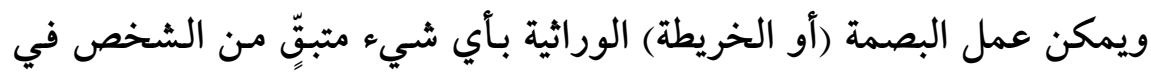

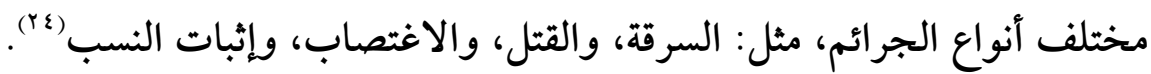

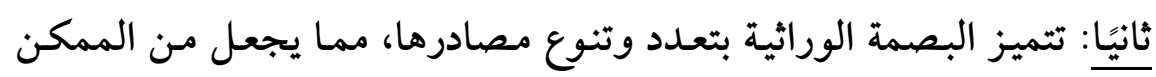

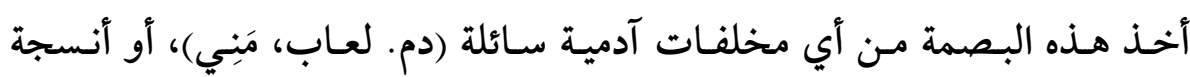

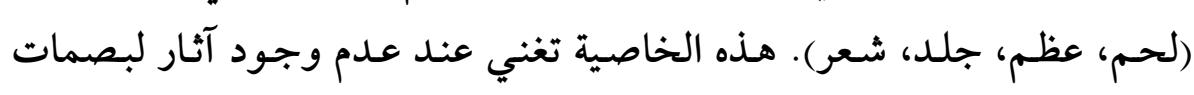

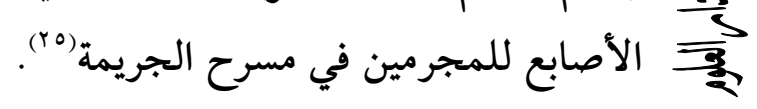

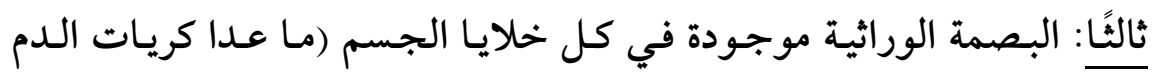

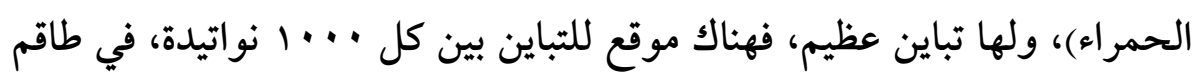

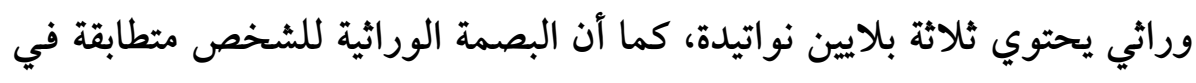

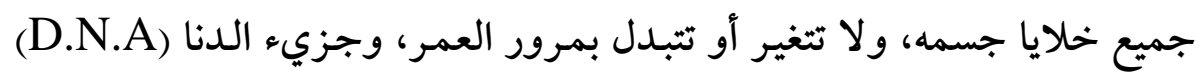

$$
\text { ثابت إلى حد كبير (r). }
$$

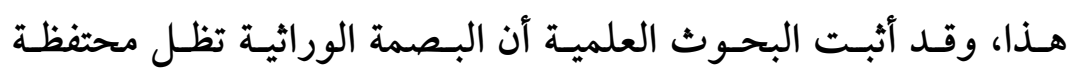

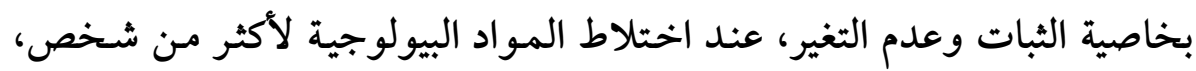

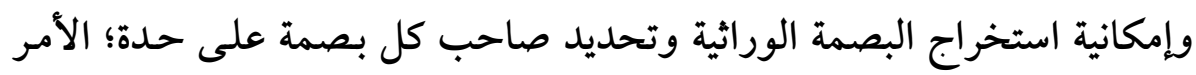

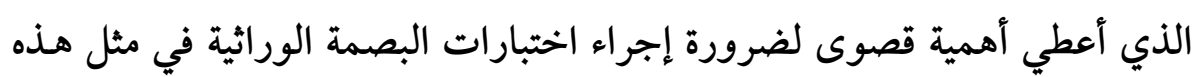

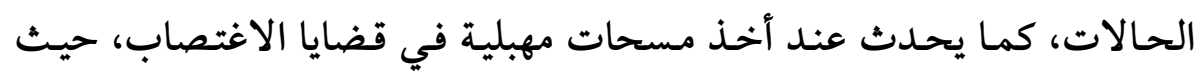

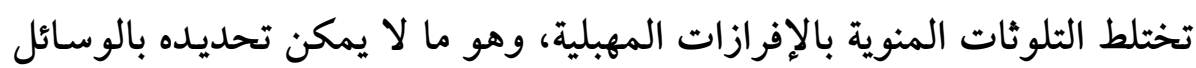

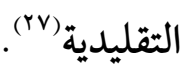




\section{إثبـات نسب اللقيط عز طريق البصمة الوراثية}

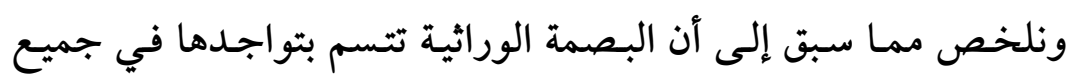

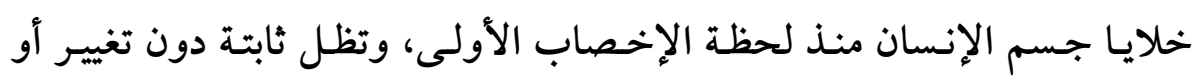

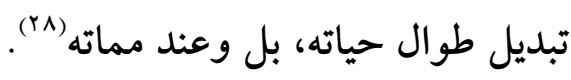

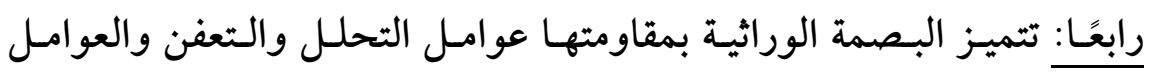

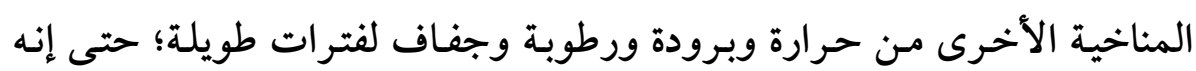

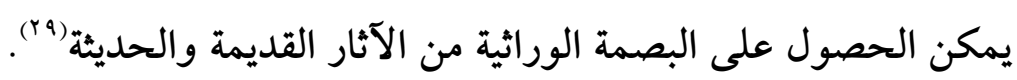

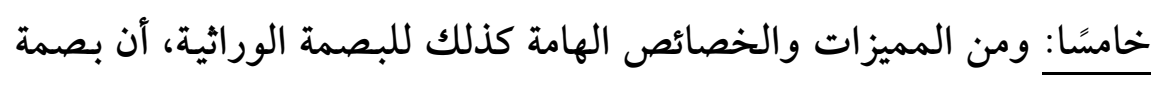
الحمض النووي تظهر على شكل خطوط عريضة يسهل قراءتها، والتعرف عليها،

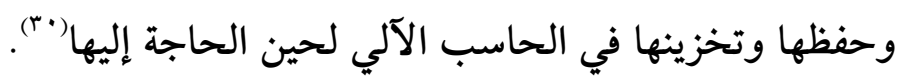

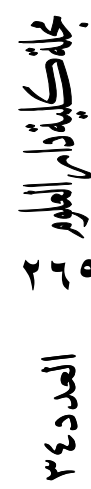

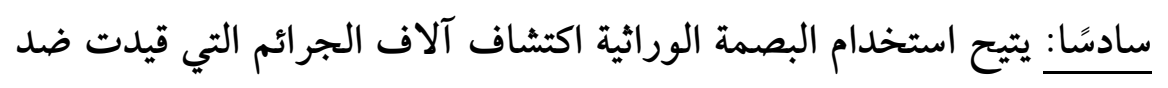

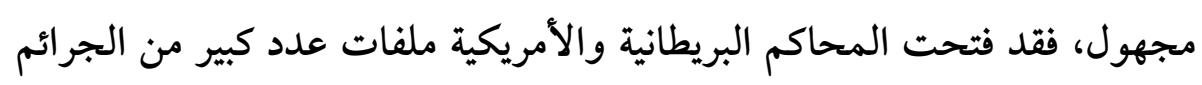

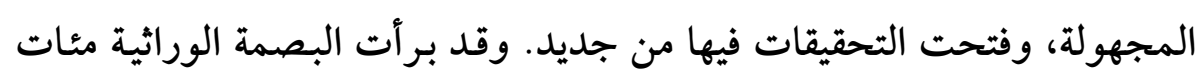

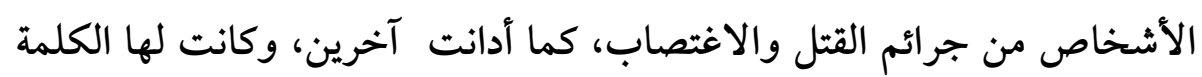
الفاصلة في قضايا الأنساب (1").

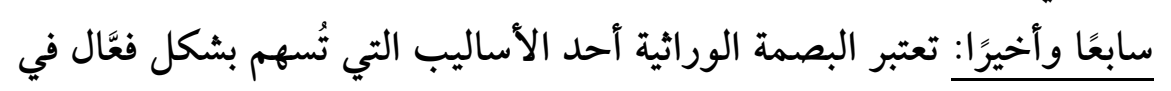
مساعدة الضحايا (ضحايا الجريمة) (بr).

\section{المبحثة الثالثة}

\section{مراحل اكتشاف البصمة الوراثية}

مرت دراسة الإنسان لذاته بعدة مراحل، عرف أولًا أن جسمه يتكون من النهاف

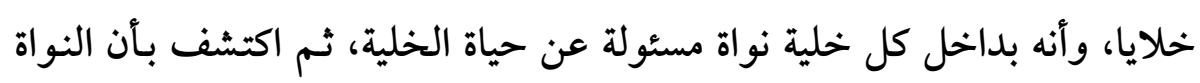

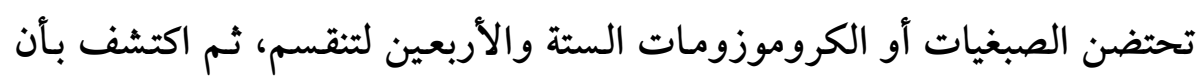

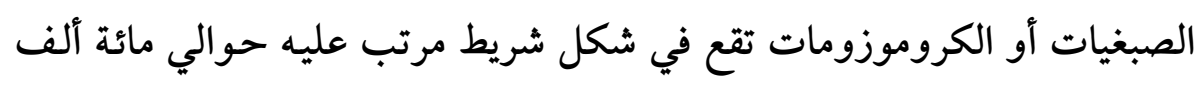

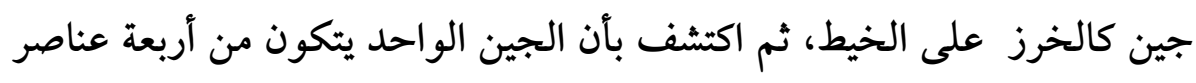
متضافرة. 


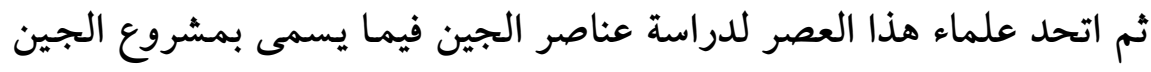

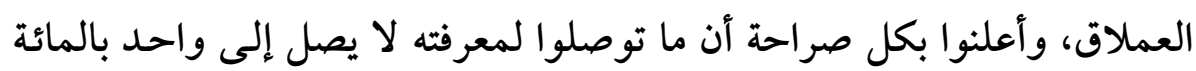

$$
\text { من أسرار هذا العلم. }
$$

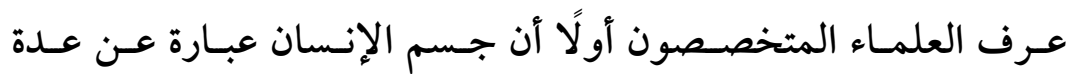

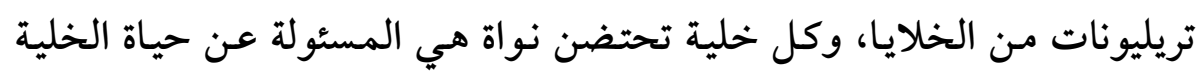

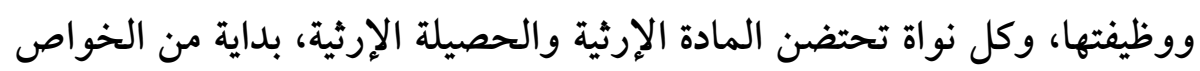

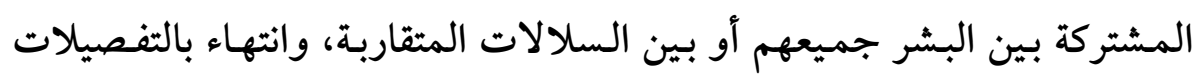

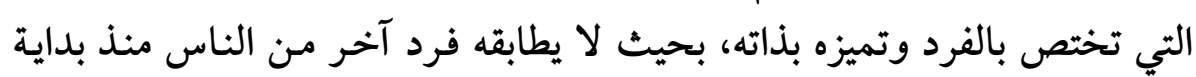
الإنسانية وحتى نهايتها.

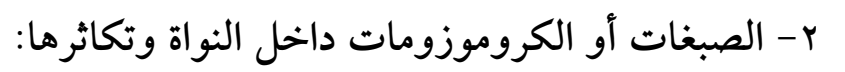

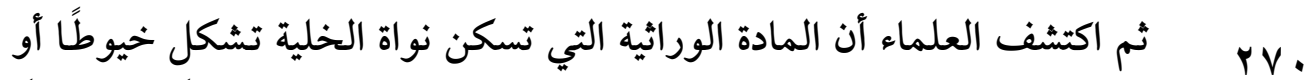

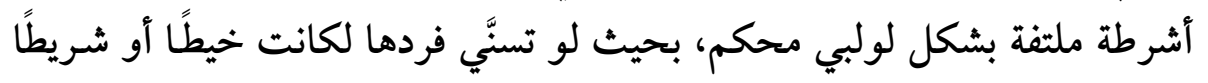

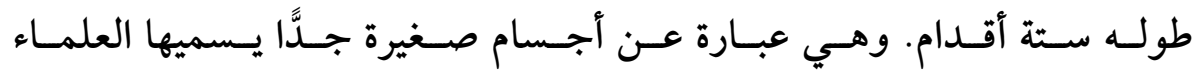

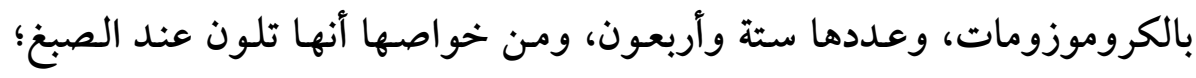
इ

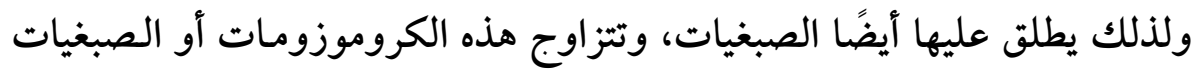

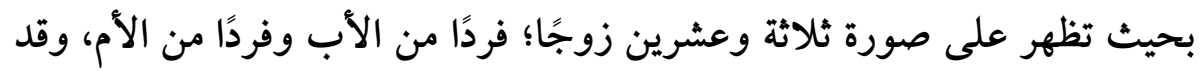

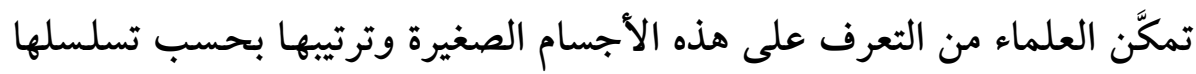

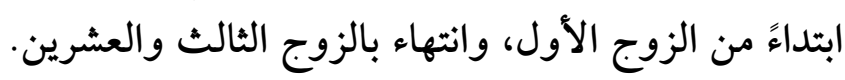

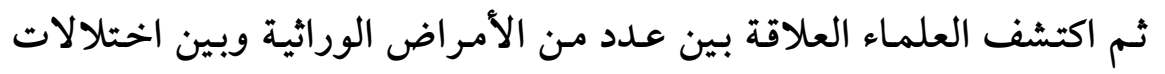

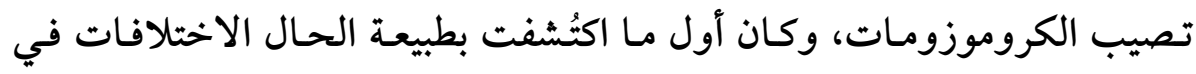

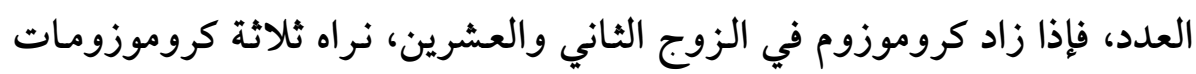
لا اثنين. 
وإذا نقص كروموزوم حتى أصبح أحد زوجي الكروموزومات فردًا واحدًا؛

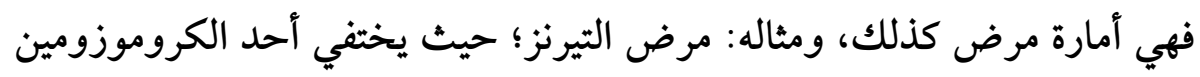
المؤنثين.

وقد تصاب الكروموزومات بالخلل وليس في عددها نقص أو زيادة، وإنما

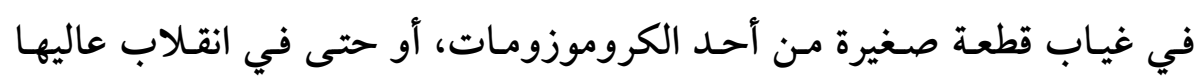
سافلها، وهو أمر يُرِّبَ أمراضًا معينة.

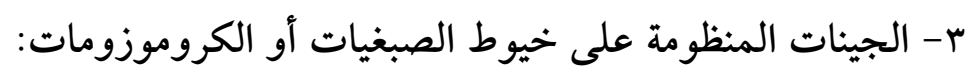

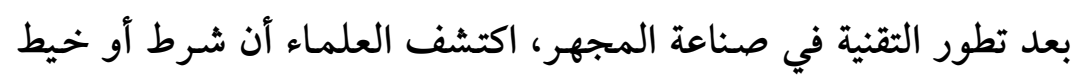

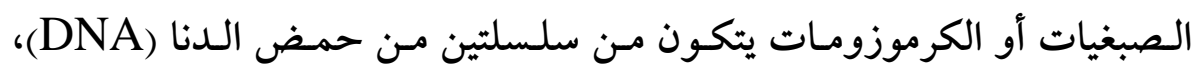

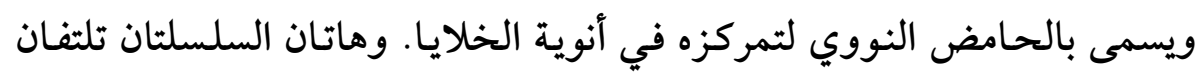

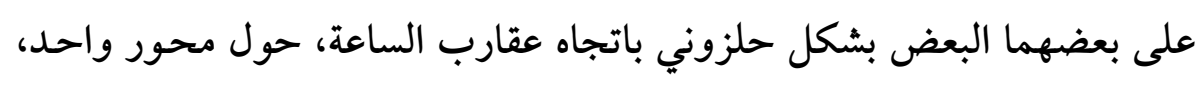

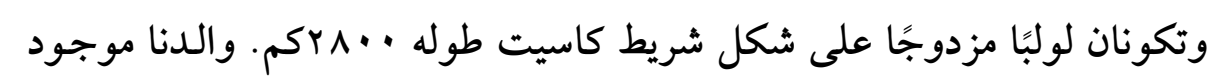

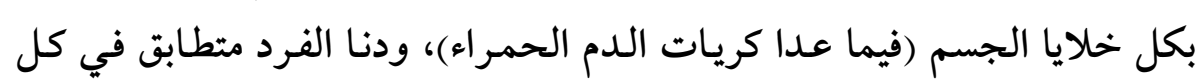

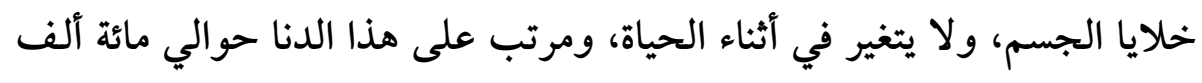
جين منظومة كالخرز على الخيط. وقيل إن عددها في كل خلية يتراوح ما بين الخمسين إلى المئل المائة ألف، وهي الخي

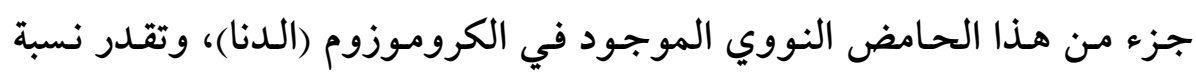

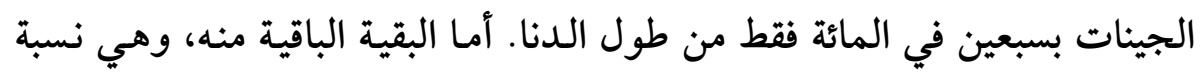
• بـ؛

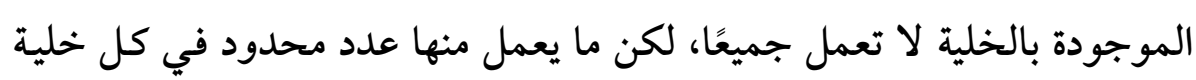
بحسب حاجة الخلية وتركيبها.

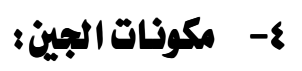

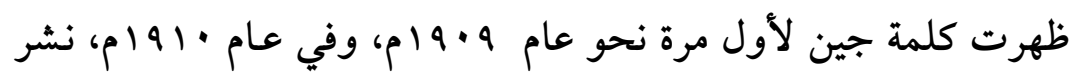

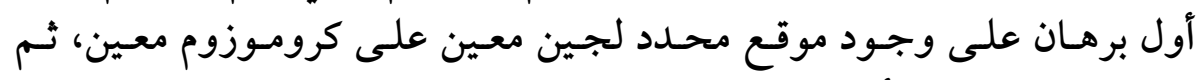

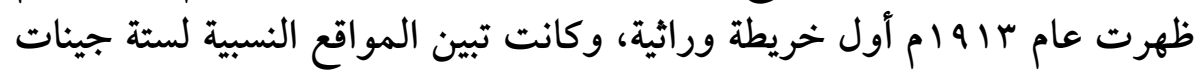


على كروموزوم واحد، ثم مع زيادة النظم التجريبية والتقنيات تغير خلال ثلاثة

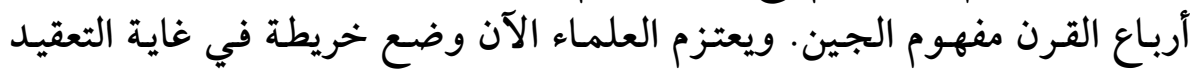

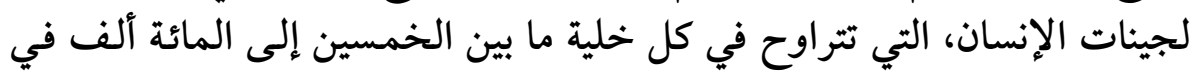

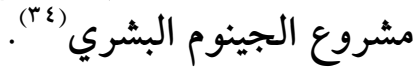

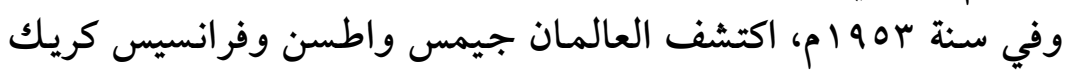

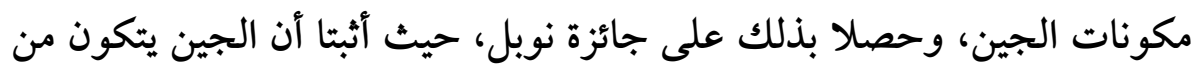
حمض النوويك، وهو بدوره يتركب من زوجين متكررين من القواعد، كل منهما

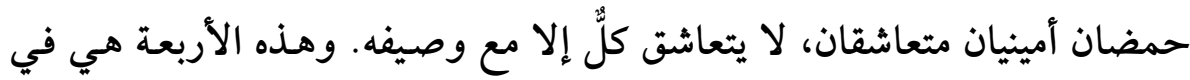

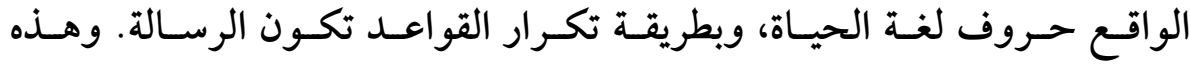

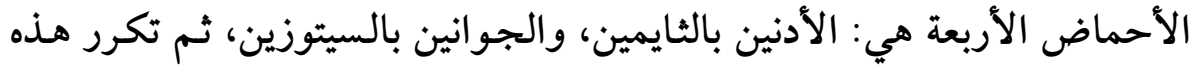

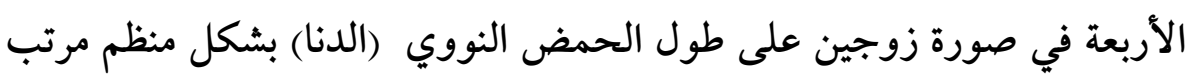

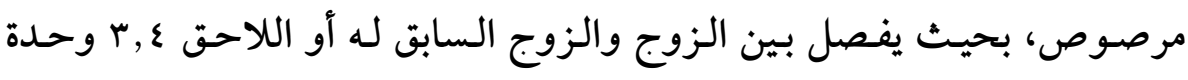

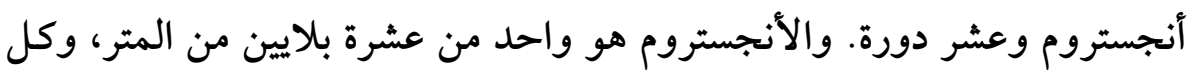

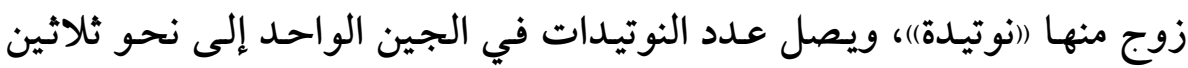
ألف نوتيدة أو زوج قاعدي. وبذلك يكون حمض الدنا في الخلية الواحدة يحتوي على مائة ألف فأل جين يتألف من ثلاث بلايين زوج من القواعد (ب0).

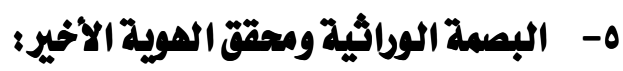

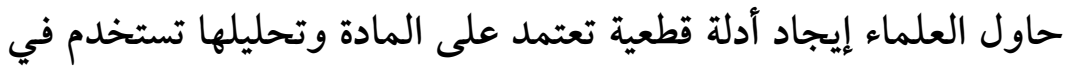

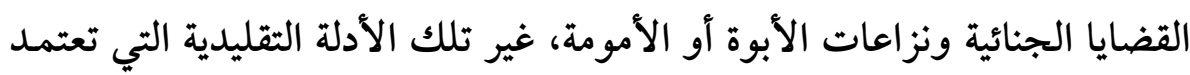

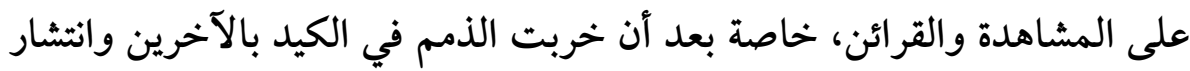

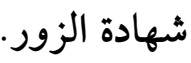
بدأ التصنيف الوراثي الشرعي باكتشاف مجموعة الدم ABO، دورئ وسرعان

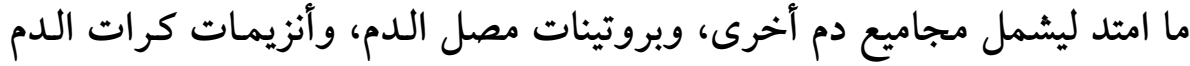

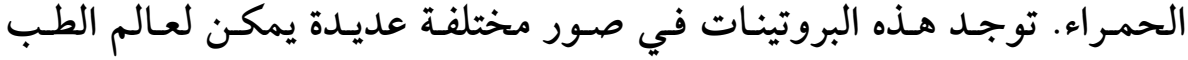

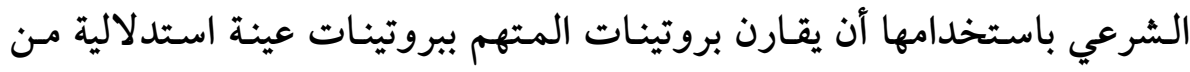




\section{إثبات نسب اللقيط عزطريق البصمة الوراثية}

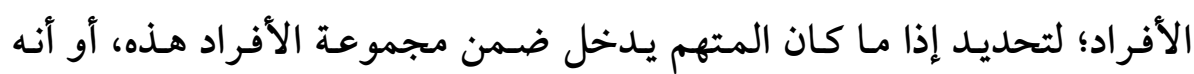

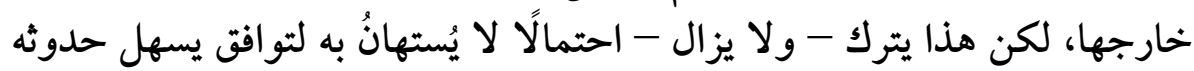

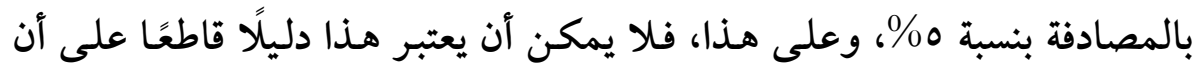

أدرك علمـاء الطب الشرعي الحاجـة إلى واسـمات وراثيـة ذات قـدرة المتهم مذنب.

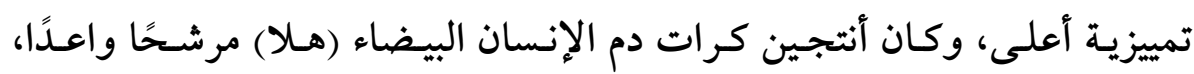

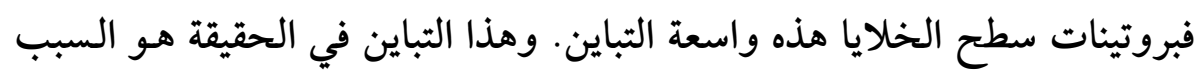

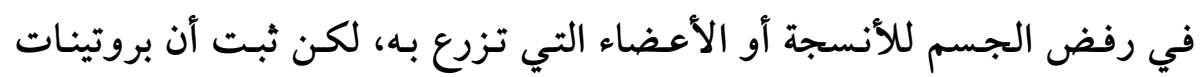

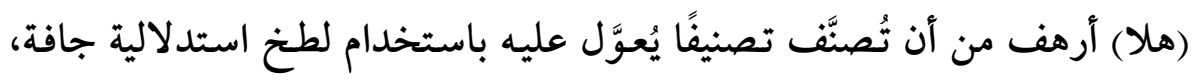

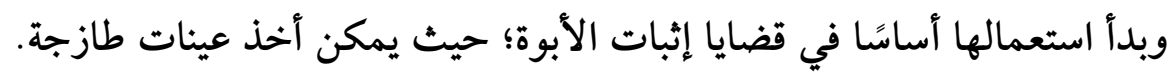

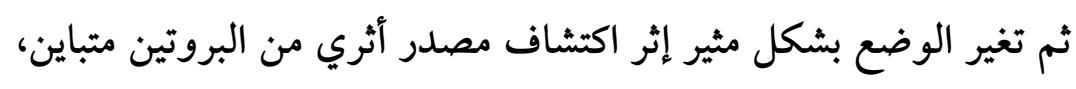

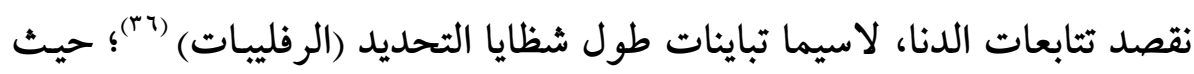

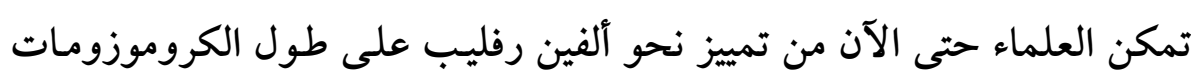
البشرية كلها.

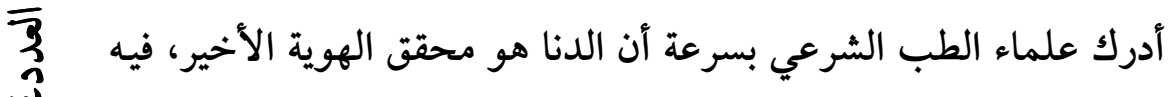

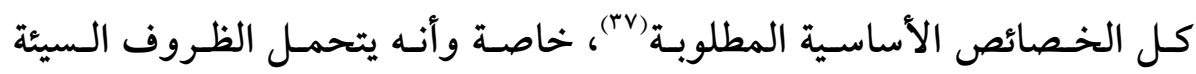

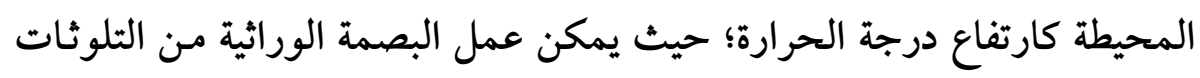

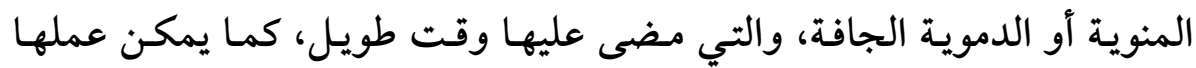

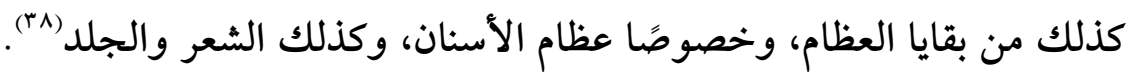




\section{الفصل الثاني}

\section{ضوابط وشروط المعل بالبصمة الوراثية \\ في إثبات ذنب الاقيط في الفقه الإسلامي}

\section{المبحث الأول :شروط العمل بـالبصمة الوراثية وضوابطها}

$$
\begin{aligned}
& \text { تقهيلد: } \\
& \text { القسم الأول: الضوابط الشرعية للعمل بالبصمة الوراثية: } \\
& \text { أهم هذه الضوابط ما يلي: }
\end{aligned}
$$

أولاً: ألا تخـالف نتـائج البـصمة الوراثيـة صـدق النصوص الشرعية المقطوع بصحتها وجلب المفاسد؛ ومن ثم لا يجوز استخدامها في التشكيك في صحة الأنساب المستقرة الثابتة وزعزعة الثقة بين الزوجين.

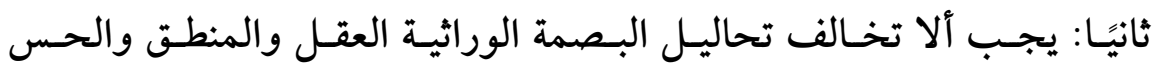

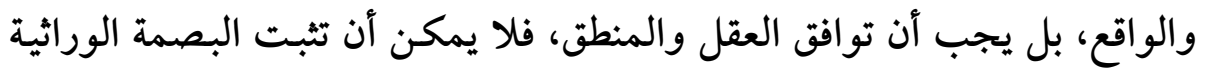

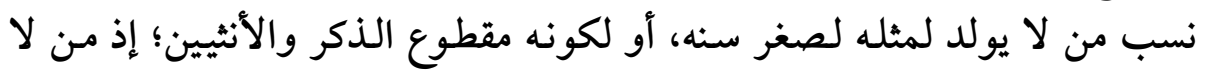

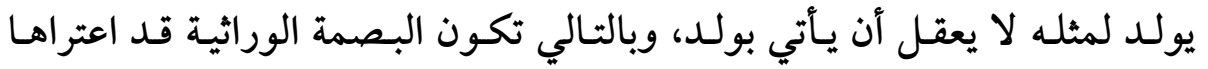

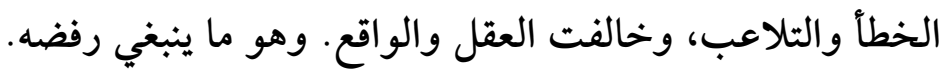




\section{إثبات نسب اللقيط عن طريق البصمة الوراثية}

ثالثًا: أن تكون أوامر التحاليل البيولوجية للبصمة الوراثية بناءً على أوامر من التِ

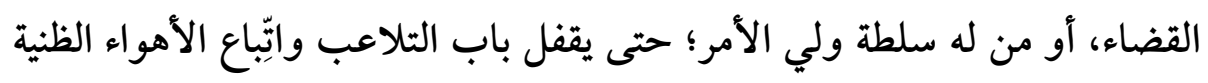
عند ضعاف النفوس.

رابعًا: أن تستعمل التحاليل الفنية للبصمة الوراثية في الحالات التي يجوز فيها

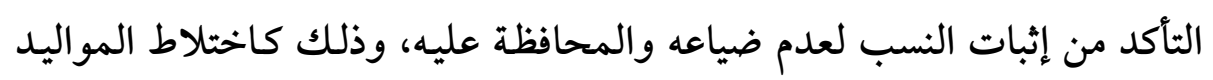

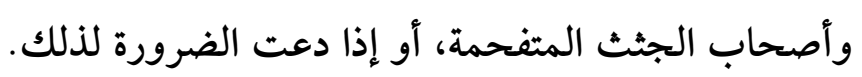

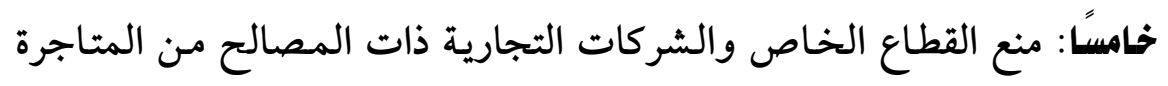

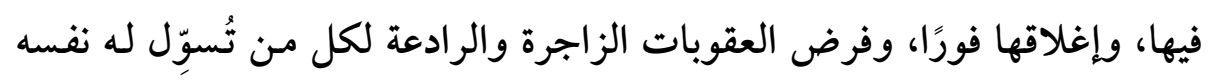

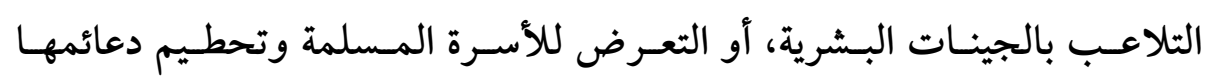

\section{القسم الثاني : شروط البصمة الوراثية من الناحية العملية:}

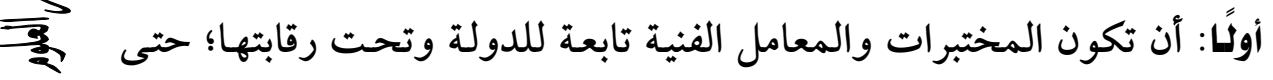

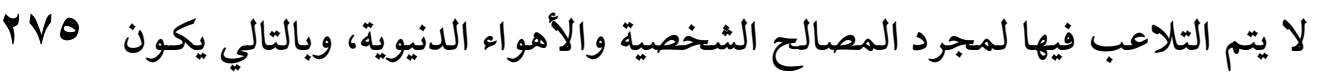

$\overline{3}$

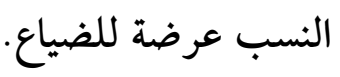

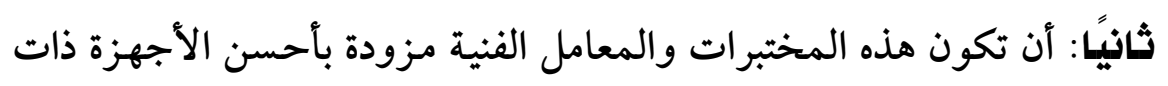

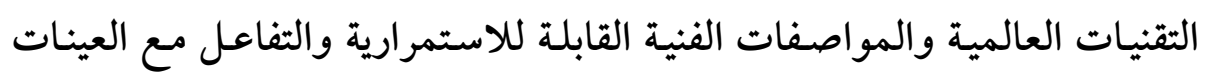
والظروف المحيطة بها في الدولة.

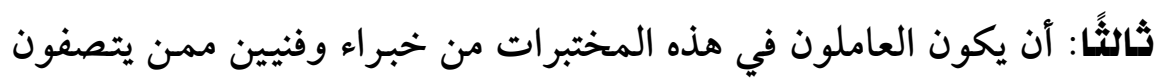

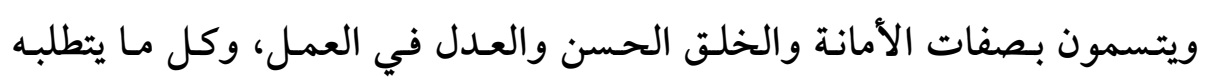
الشرع في سبيل درء المفاسد وجلب المصالح.

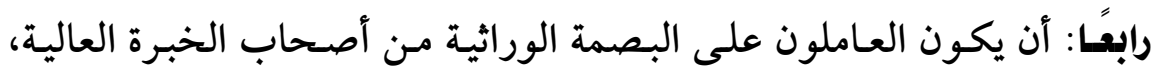

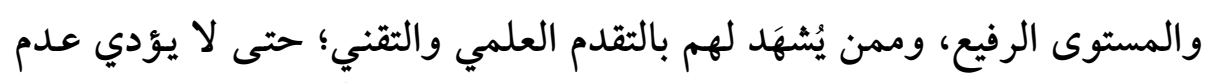

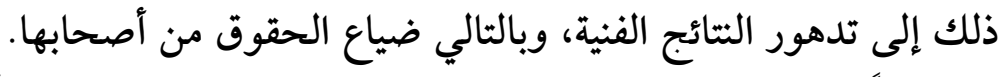

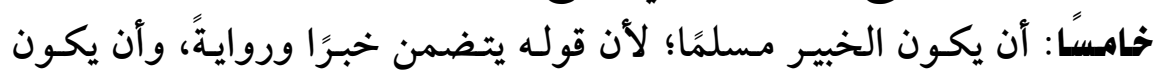

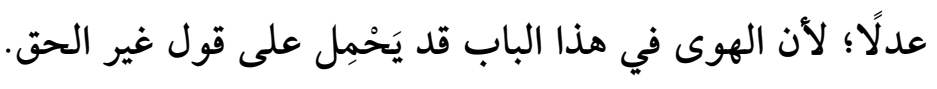


سادسًا: ينبغي أن لا يقبل قول الخبير في البصمة الوراثية إذا كان يجر بذلك

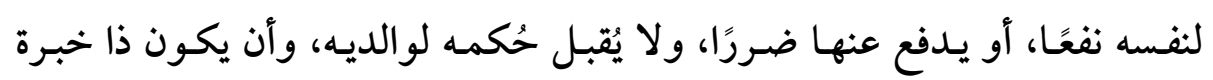

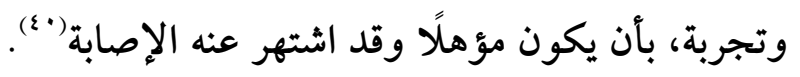
سابعًا: شرط التعدد بين المؤيدين والمعارضين: والمقصود بالتعدد هو تعدد الخبـراء الفنيين القـائمين على العمـل في البـصمة الوراثية قياسَا على الشهادة والقيافة. وهذا رأي الأغلبية من فقهاء العصر (1).

\section{المبحث الثاذي : تعريف الاتيط وحكم الثقاطه}

\section{وفيه}

\section{المطاب الأول : تعريف الاقيط}

أونًا: اللقيط لغة: مـن اللقط، فعيل بمعنى مفعول، يقال: (القيط)) و (ملقوط)) و ((ملتقط)، و ((اللقط )) أخـذ الشيء بـلا تعـب. هـذا هـو الأصـل في هـذه الكلمـة. واللقيط اسم للشيء الذي تجده ملقَى على الأرض من غير قصد ولا طلب. وقد

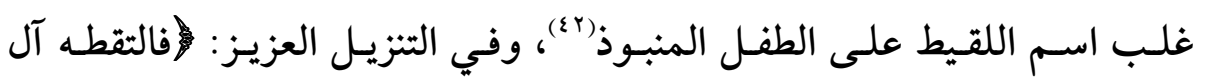

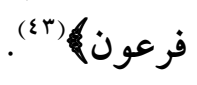

بهذا يكون اللقيط هو الطفل الذي يوجد على الأرض لا يُعَف أبواه، فيلتقط

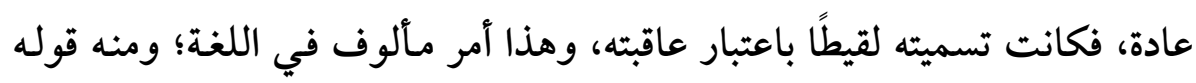

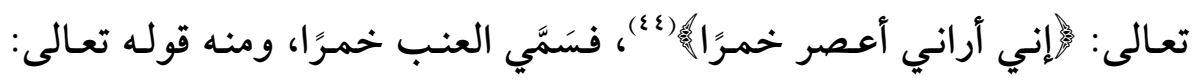

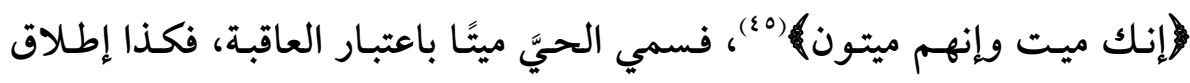
كلمة لقيط على الطفل الذي يوجد ملقًى على الأرض في الطريق العام.

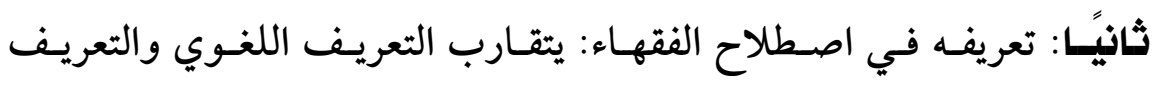
الاصطلاحي، إلا أنه في التعريف الاصطلاحي يوجد نوع من الحصر والتحديد في ماهيته. وهذا ما سيتضح لنا من خلال التعريفات التالية:

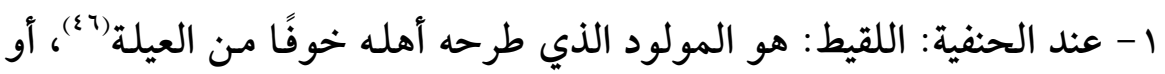

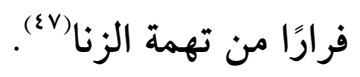




\section{إثبات نسب اللقيط عزطريق البصمة الوراثية}

r- عند المالكية: صغير آدمي لم يُعلَم أبواه ولا رقُه، أو: هو صغير لا قدرة له

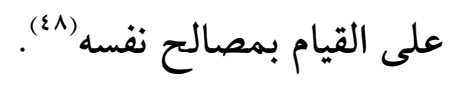

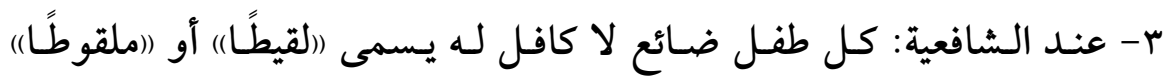

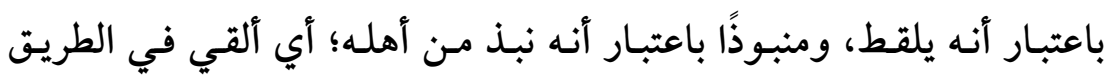

$$
\text { ونحوه }
$$

ع - عند الحنابلة: (اللقيط)) طفل لا يُعرَف نسبُه ولا رقُّه، نُبذ أو ضَلَّ إلى سن

$$
\text { معينة (o.) }
$$

تعقيب وتوضيح: يفهم من تعريف الحنفية أن اللقيط مقتصر على المولود -

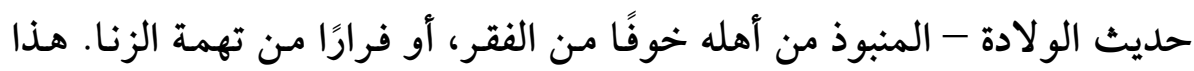

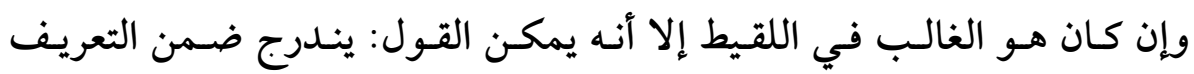

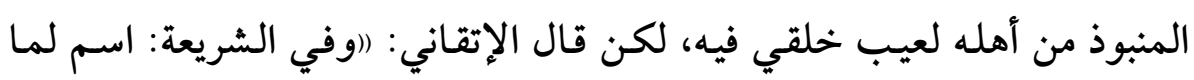

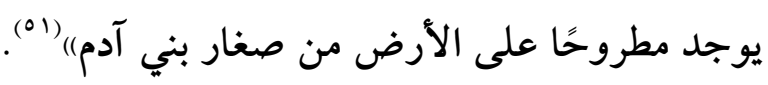

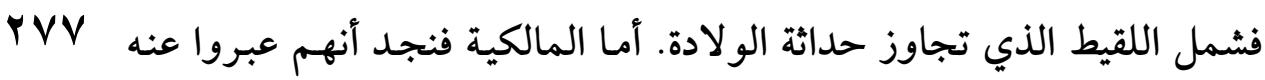

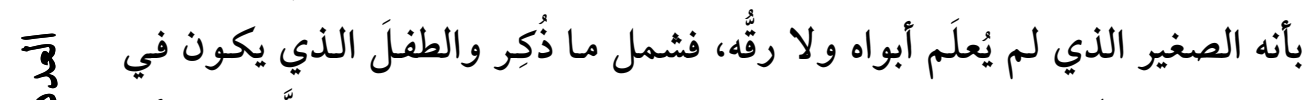

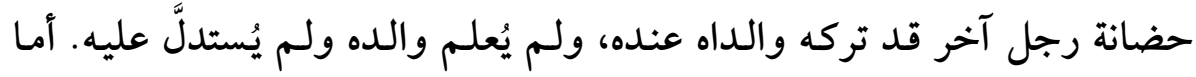

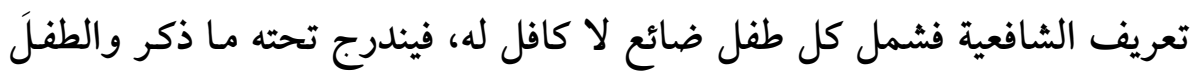

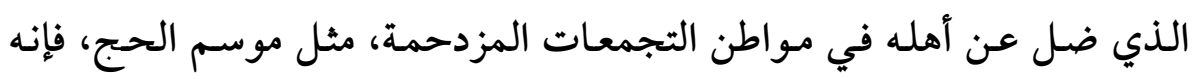

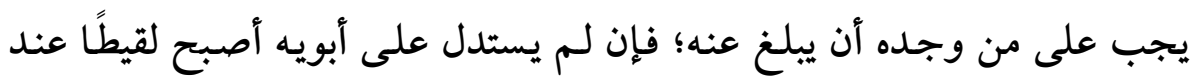

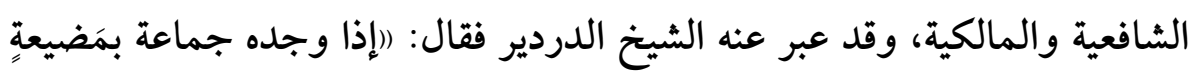

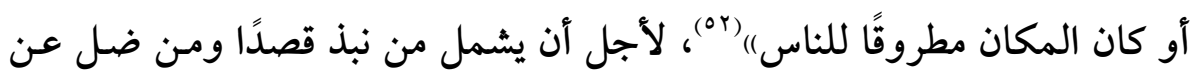

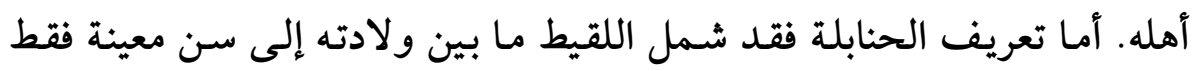
على الصحيح، قال في الإنصاف: (اوعند الأكثر إلى البلوغ)|"(or).

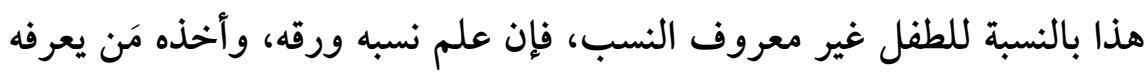

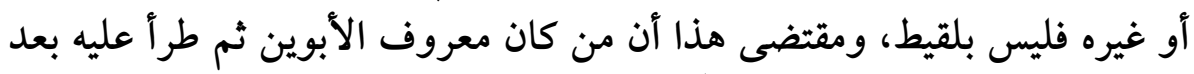

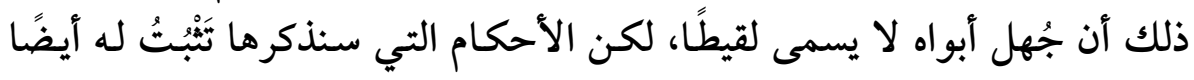


من أجل حفظه ورعايته، وعلى هذا يمكن تعريف اللقيط بتعريف شامل أنه:

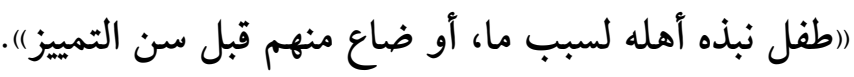

\section{المطلب الثاني : حكم الاتتقاط}

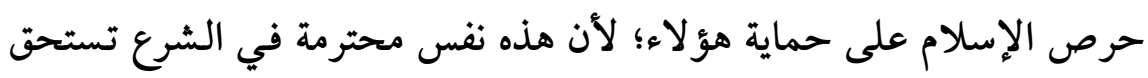

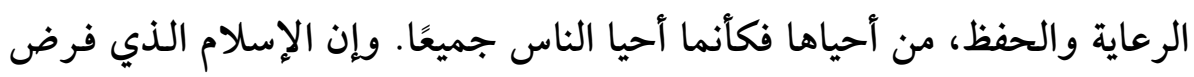

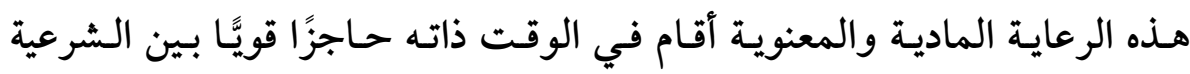

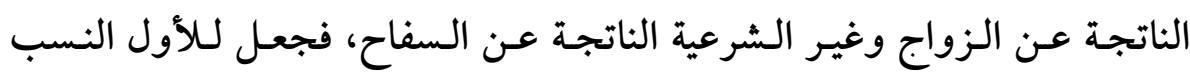

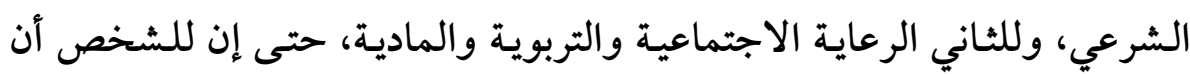

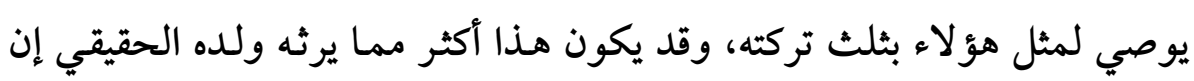

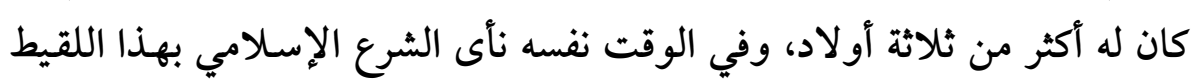
عن الضياع؛ فكفل له حقوقه التي تجعله يعيش بأمان.

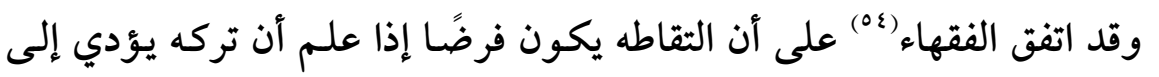
A

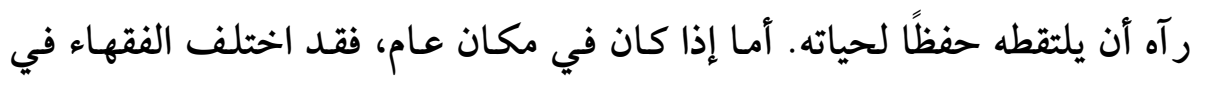
درجة طلب الشرع لالتقاطه على ثلاثة آراء:

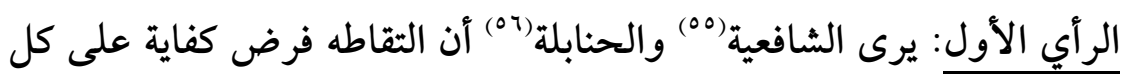

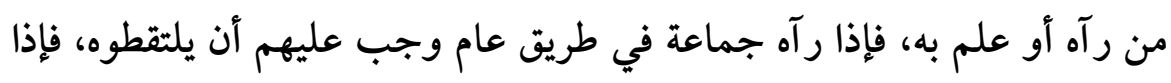

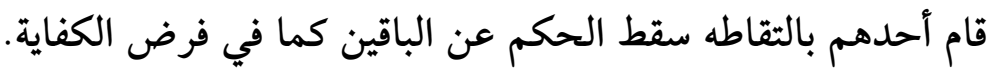

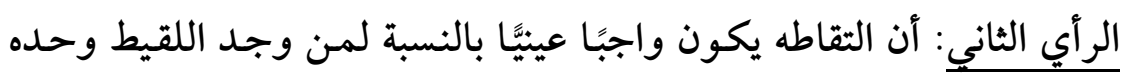

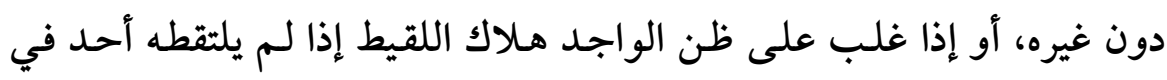

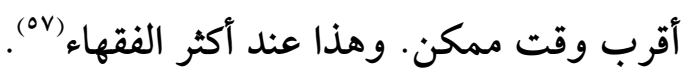

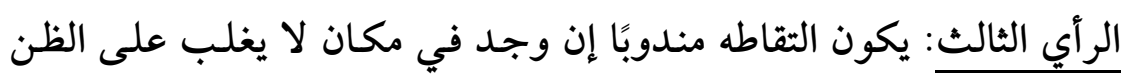

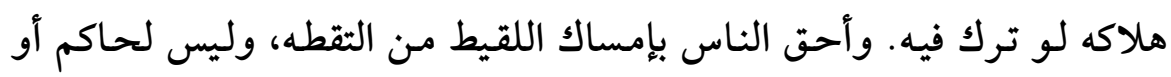

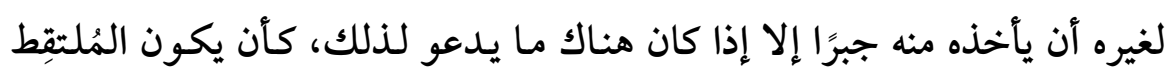
غير أهل لحفظه ورعايته. وهذا عند الحنفية (م). 


\section{المبجث الثالث}

\section{إجراء البصمة الوراثية لتحقيق ذنب اللقيط}

النسب في اللغة يطلق على معانٍ عدة؛ أهمها: القرابة والالتحاق، تقول: فلان

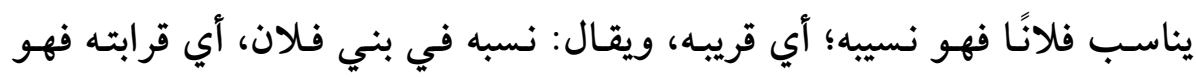

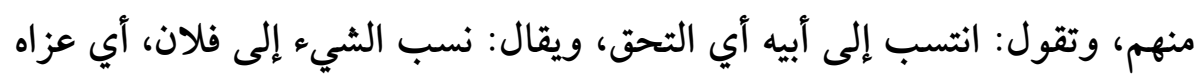

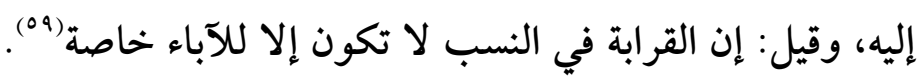

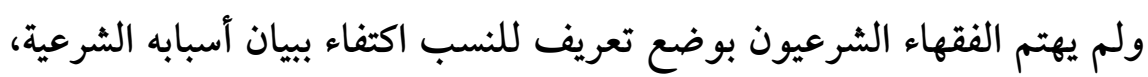

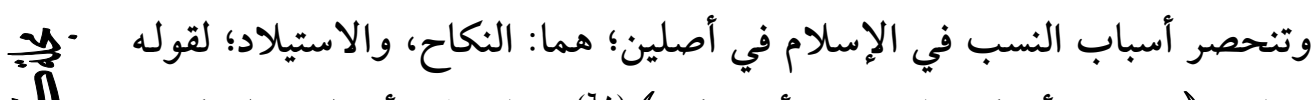

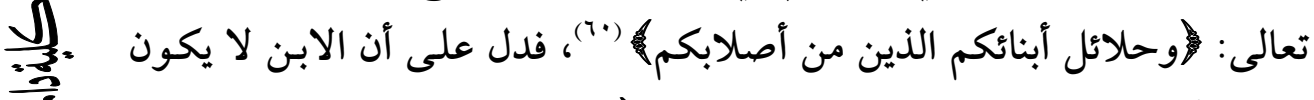

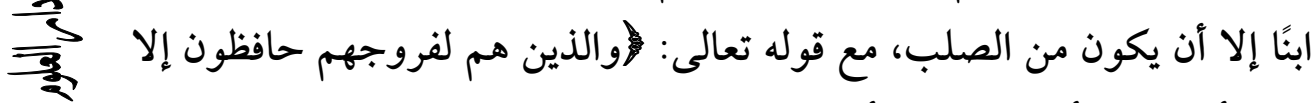

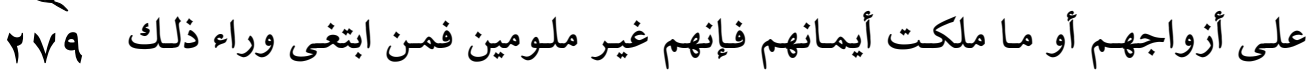

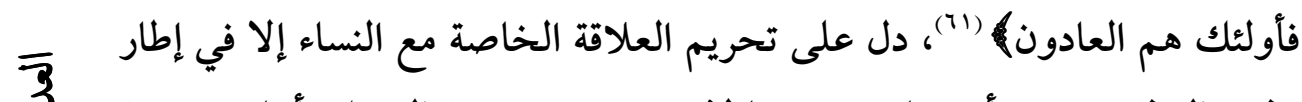

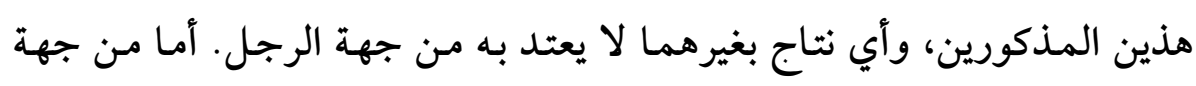

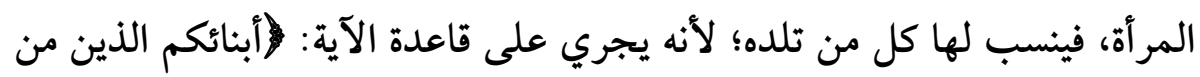

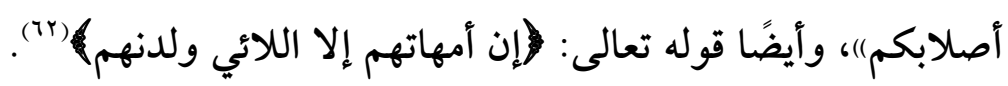

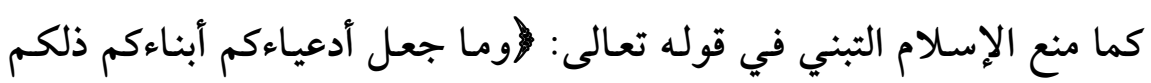

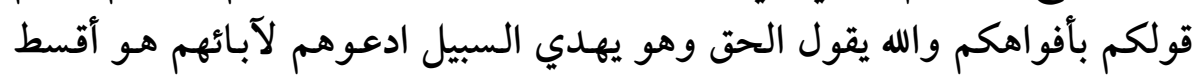

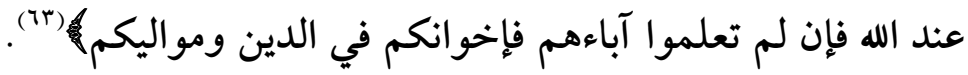

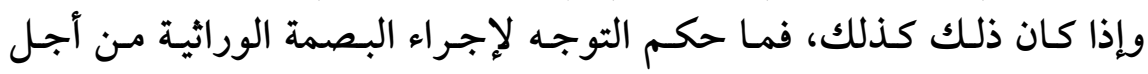

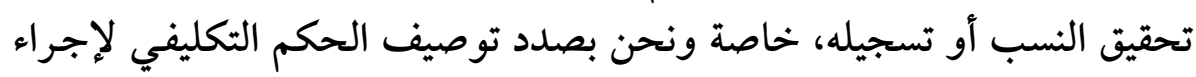
البصمة الوراثية؟

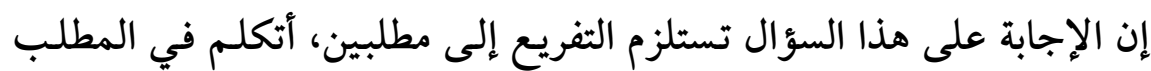

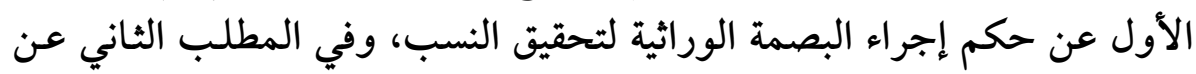
حكم إجراء البصمة الوراثية لتسجيل النسب. 


\section{المطلب الأول :إجراء البصمة الوراثية لتحقيق نسب اللقيط}

قد يحلو للبعض بعد ثبوت صحة نتائج البصمة الوراثية أن يتجه إلى تحقيق

$$
\text { نسبه أو نسب غيره. }
$$

والمقصود بالتحقيق هنا: التأكد والتثبت من نسب قائم بالفعل، أو حسم نزاع

لنسب مختلف فيه.

$$
\text { ويدور البحث في هذا المطلب في الإجابة على سؤالين: }
$$

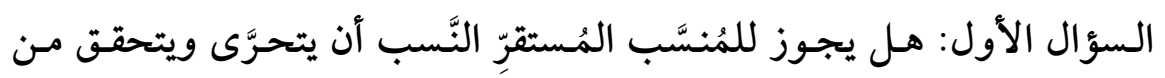

$$
\text { نسبه شرعًا بالبصمة الوراثية؟ الاول: هل يجوز }
$$

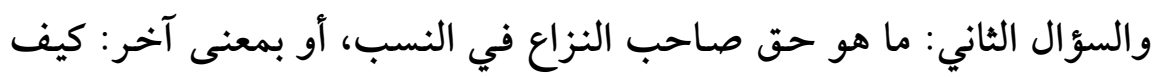

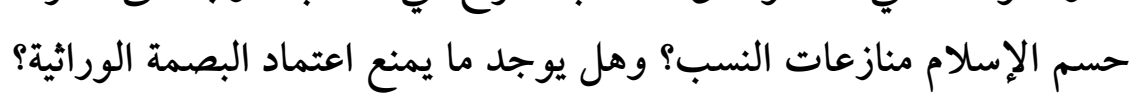

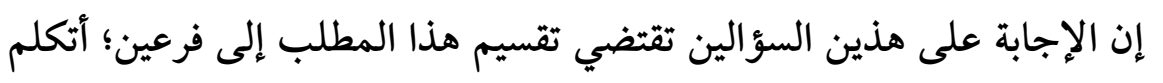

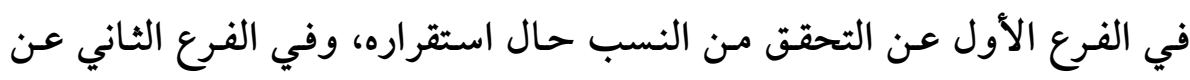
التحقق من النسب عند التنازع.

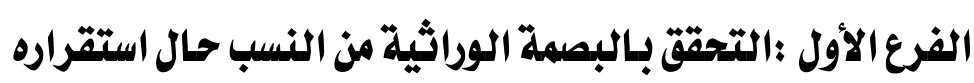

\section{تقهيد:}

النسب المستقر هو النسب الثابت بأحد أدلة ثبوته في الفقه الإسلامي (18)،

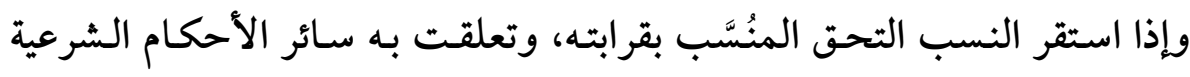

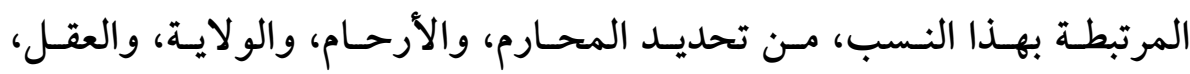

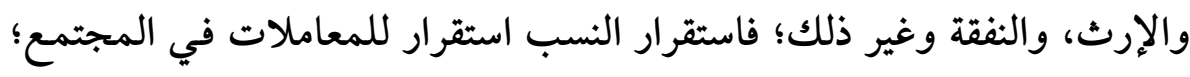

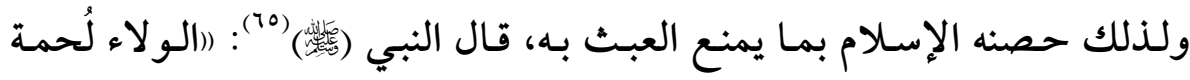

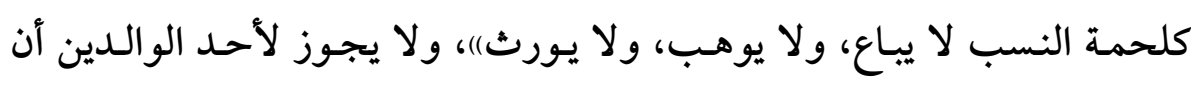

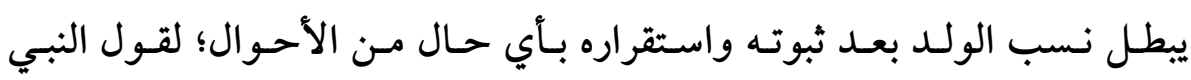

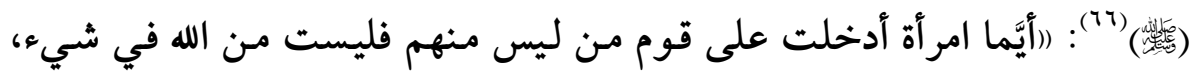

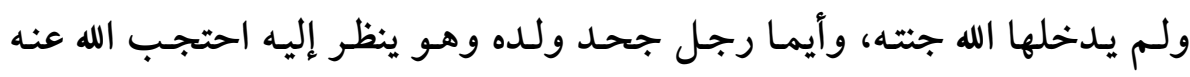
وفضَحه على رءوس الأولين والآخرين)،، وعن عمر (رضي الله عنه)، قال (TV): 


\section{إثبات نسب اللقيط عزطريق البصمة الوراثية}

والآخرين)،، وعن عمر (رضي الله عنه)، قال (TV): (امَن أقرَّ بولده طرفة عين فليس

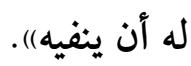

يقول الصنعاني: في هذا دليل على أنه لا يصح نفي الولد بعد الإقرار به، وهو مجمع عليه (T1).

أقول: وإذا لم يحل لأحد الأبوين أن ينفي عنه الولد؛ فلا يحل أيضًا من باب

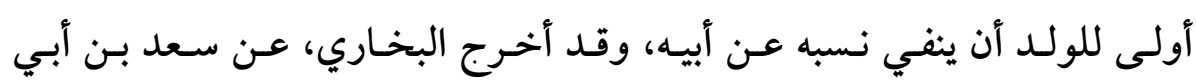

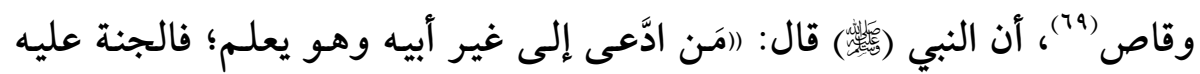

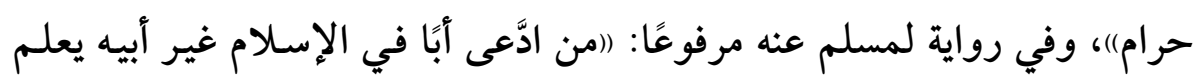
أنه غير أبيه؛ فالجنة عليه حرام).

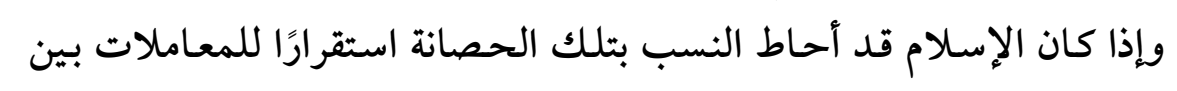

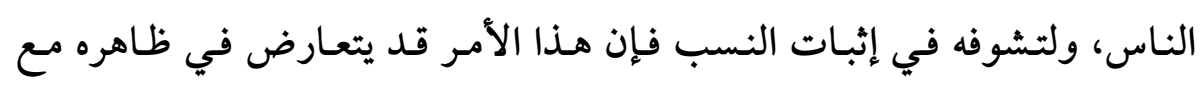

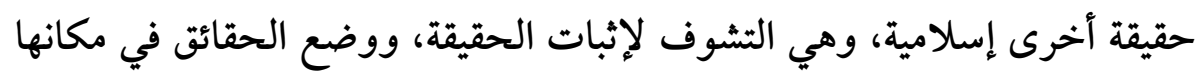

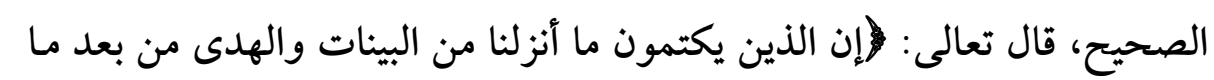

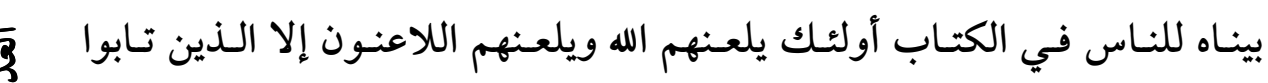

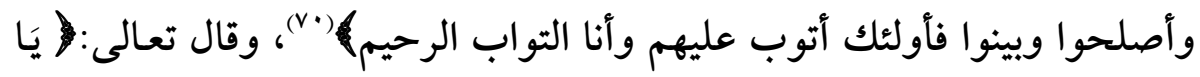

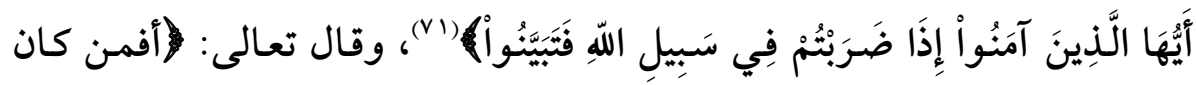

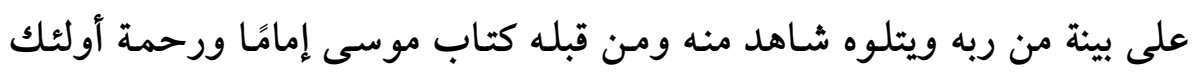

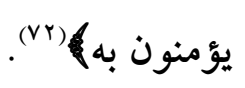

فكل تلك الآيات وغيرها كثير تأمر بالتبيُّن والتبعُّر والتبثئت للحقائق، فهل

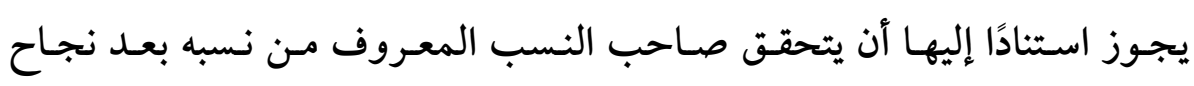
البصمة الوراثية؟ البئ

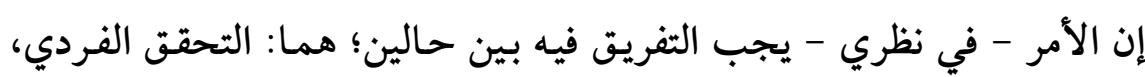

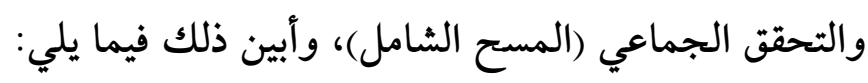




\section{أونًا : التحقق الفردي للنسب:}

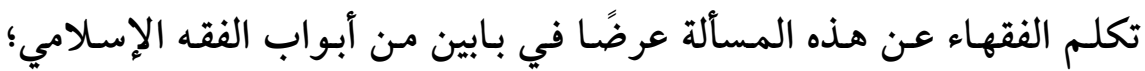

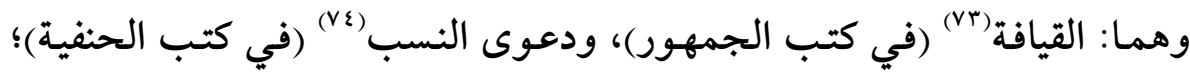

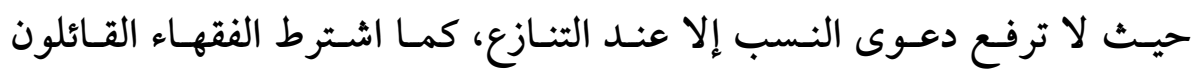

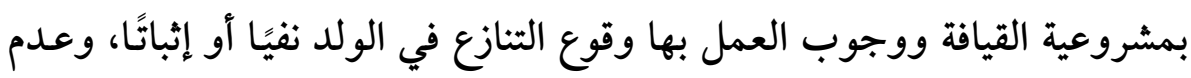

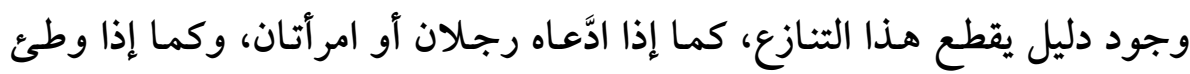

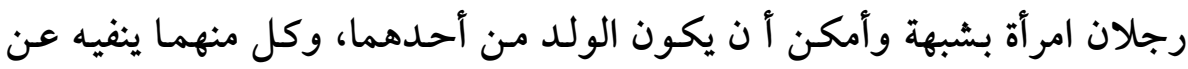

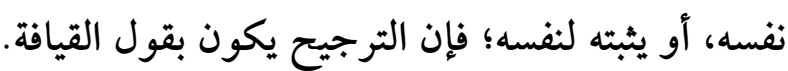
وبهذا يظهر أنه لا يجوز لمن عرف نسبه بوجه من الوجوه الشرعية أن يطلب تحقيق نسبه بالنظر إلى الشبه بالقيافة. ثانيًا : التحقق الجماعي للنسب (المسح الشامل ) :

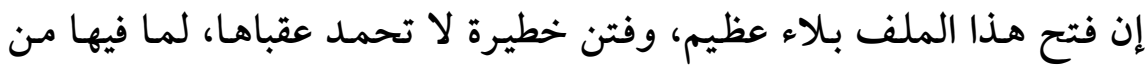

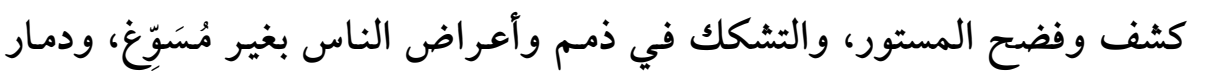
لأواصر التراحم بين ذوي القربى، ونقض لما أبرمه الإسلام من استقرار.

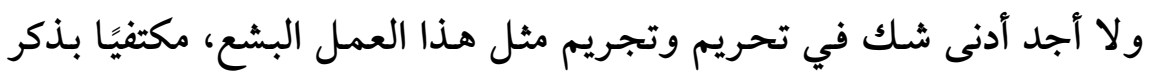
بعض الأدلة للرد على هواجس النفس الشريرة الخبيثة.

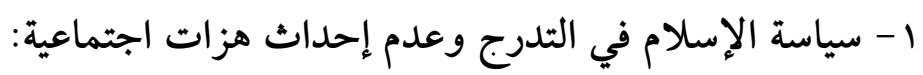

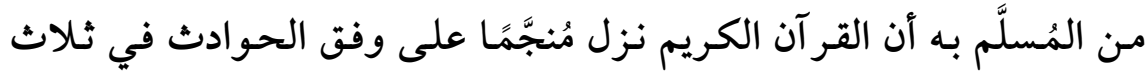

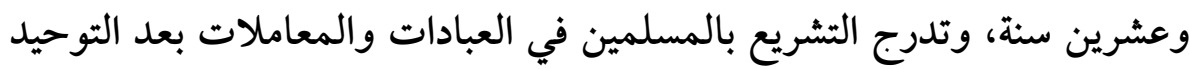

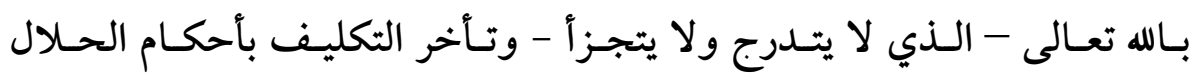
والحرام سنوات من أجل تأهيل الناس، وتعمير محطة الاستقبال عندهم.

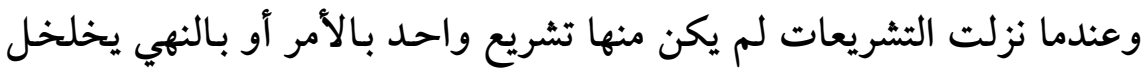

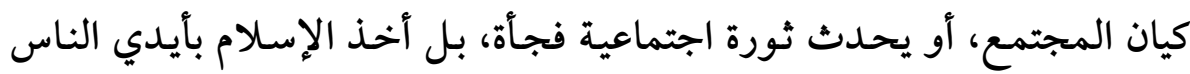
الهوينى إلى بر الأمان وكمال التشريع. 


\section{إثيات نسب اللقيط عنطريق البصمة الوراثية}

وأكتفي بذكر مثال واحد في أحكام الزواج، بعد أن أحكمه الله بعقد وميثاق

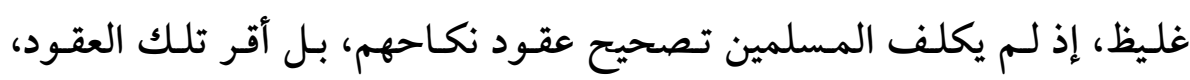

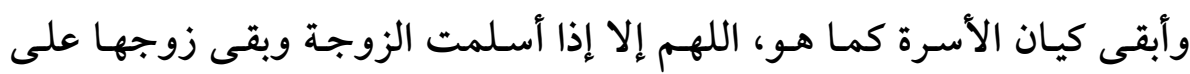

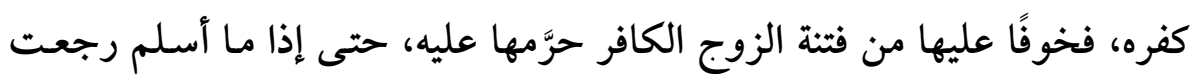

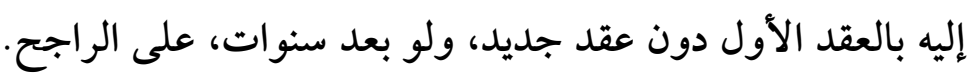

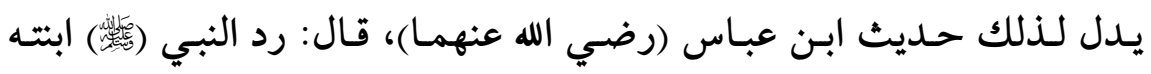

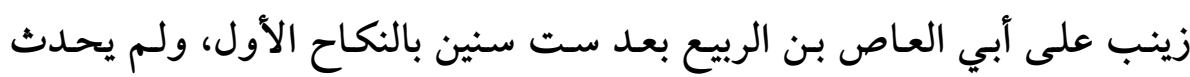

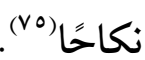

أقول: وإذا ما تحققنا من تلك السياسة الإسلامية، فكيف يقول عاقل بإمكان

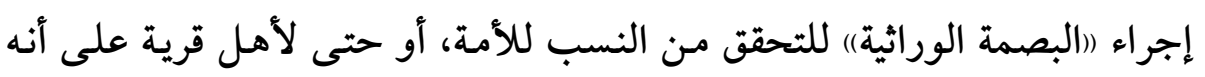

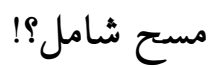
r- سياسة إقرار شرائع ما قبل الإسلام على أهلها:

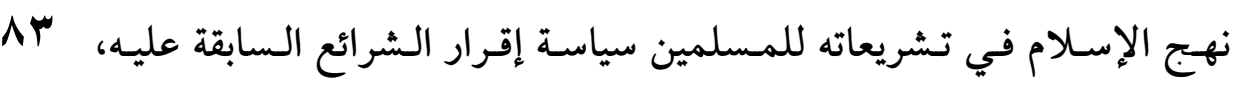

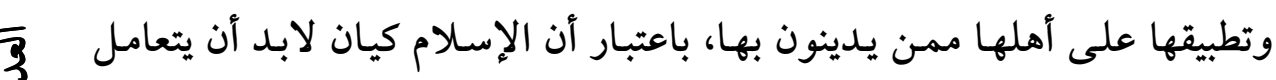

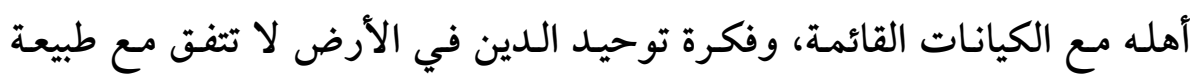

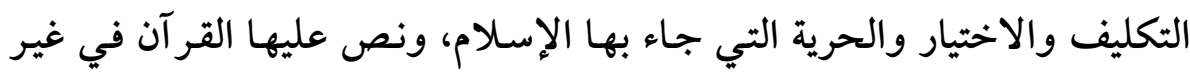

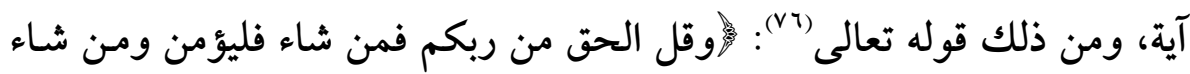

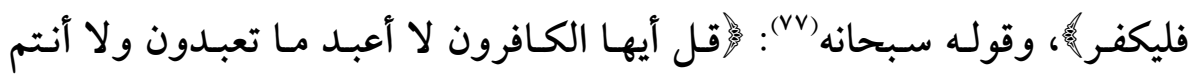

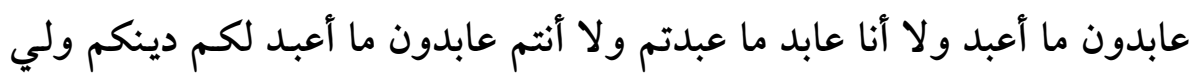
دين. r- نهي الإسلام عن الفتن وإشاعة الفواحش واتِّباع خطوات الشيطان:

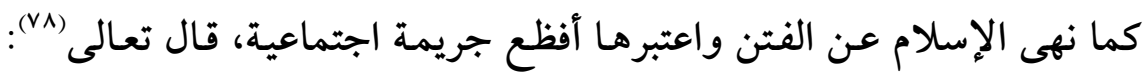

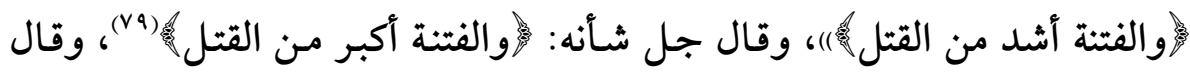

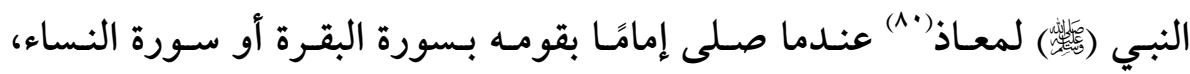

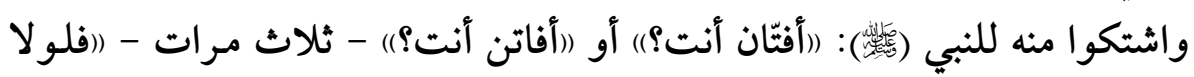


صليت بسبح اسم ربك، والشمس وضحاها، والليل إذا يغشى؛ فإنه يصلي وراءك

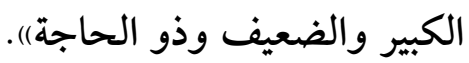

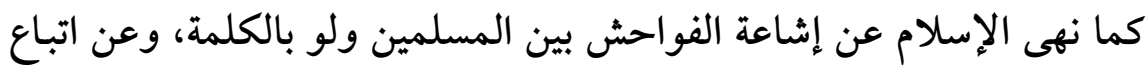

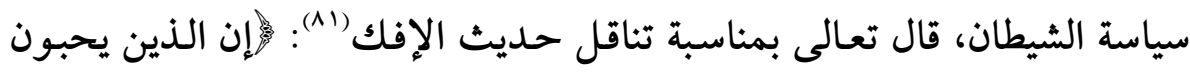

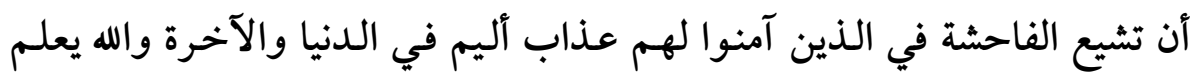
وأنتم لا تعلمون. ولولا فضل الله عليكم ورحمته وأن الله رعوف رحئ رحيم يا أيها

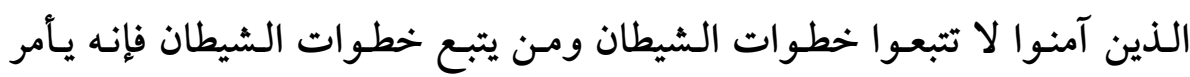

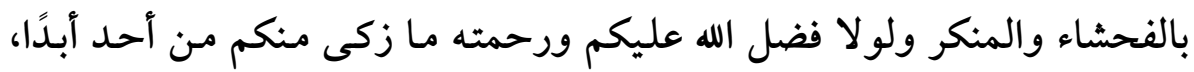

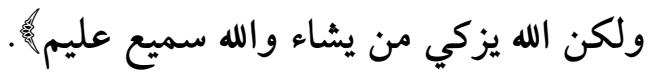

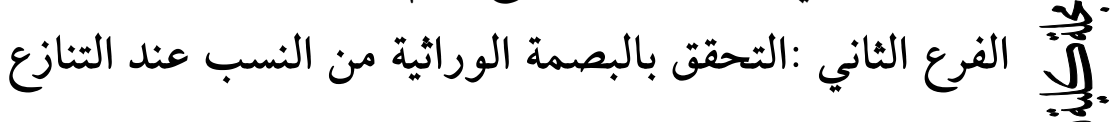
تمهيد:

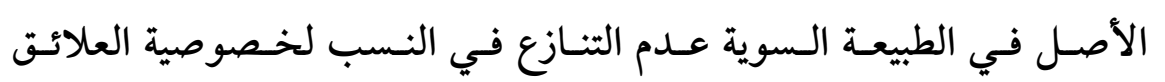

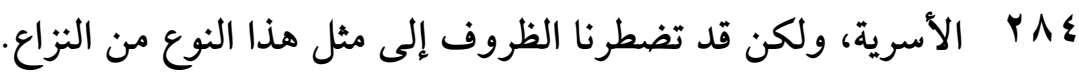

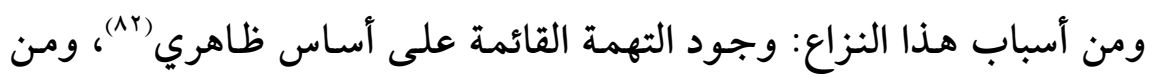

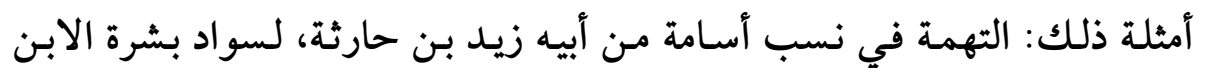

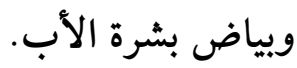
ومن أسباب هذا النزاع: اللقيط، إذا ادعى نسبه رجلان فأكثر، ومنه: اختلاط

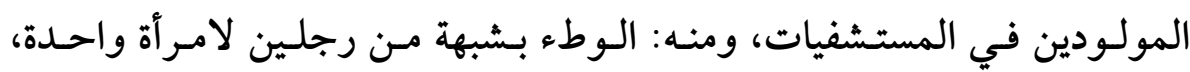

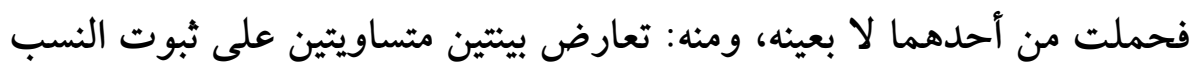

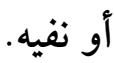

في مثل هذه الحال، كيف يمكن لنـا فضُّ النزاع وحسم النسب ولا دليل مرجح? لقد اختلف الفقهاء في الإجابة على هذا السؤال، ويمكن إجمال أقوالهم في

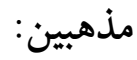




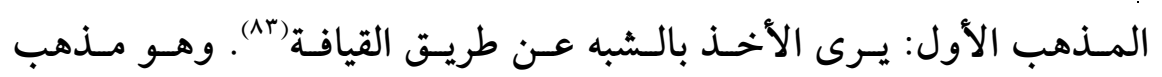
الجمهور.

فإن تنازع القافة، فقد اختلفوا على أقوال أربعة؛ قيل: يحتكم للقرعة، وقيل: يخير الولد، وقيل: يلحق بهما جميعًا، وقبل: يضيع نسبه.

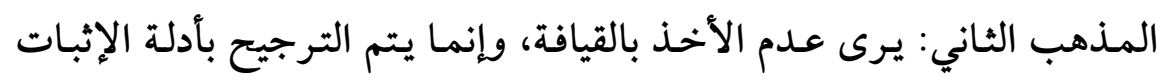

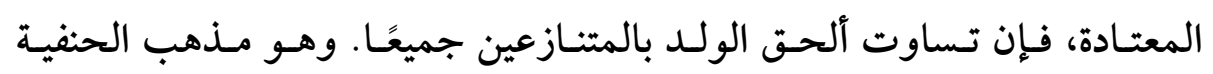
والهادوية.

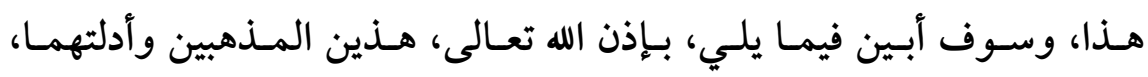

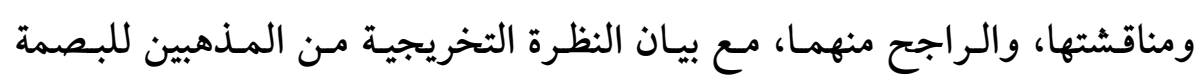

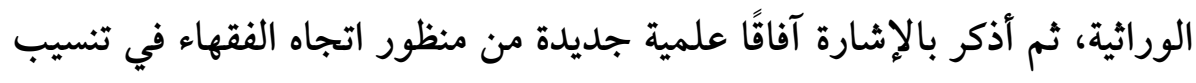
الولد للمتنازعين عند التعارض المطلق.

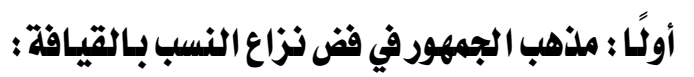

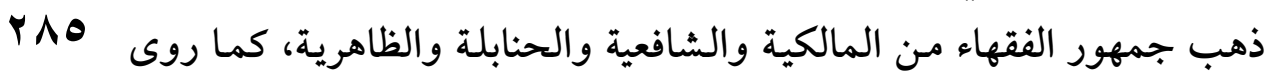

率

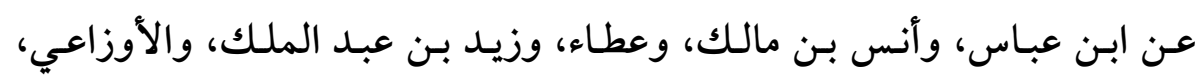

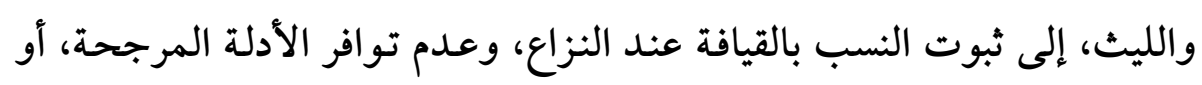
عند تعارضها، واستدلوا على ذلك بالسنة والمأثور والمعقول (1).

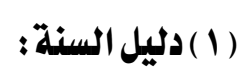

استدل الجمهور على حجية القيافة من السنة بحديثين؛ وهما:

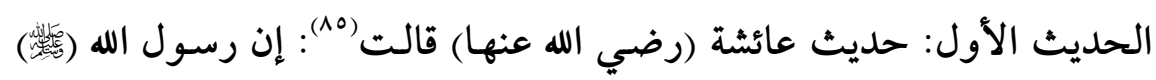

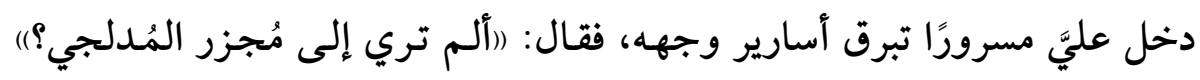

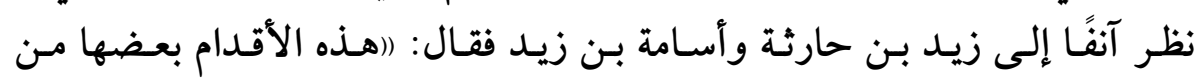
وفي رواية للبخاري: "ألم ترى أن مجزرًا المدلجي دخل فرأى أسامة وزيدًا وعليهما قطيفة قد غطيا رءوسهما ومدت أقدامهما، فقال: إن هذه الأقدام

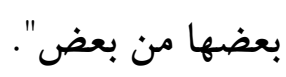


وفي سنن أبي داود: أنهم كانوا يقدحون في نسب أسامة؛ لأنه كان أسود

شديد السواد مثل القار، وكان زيد أبيض مثل القطن.

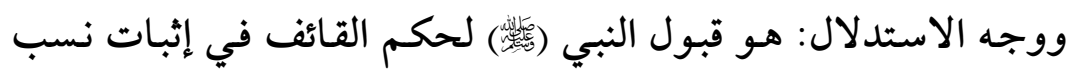

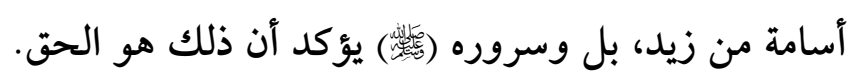

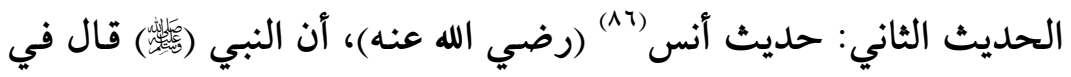

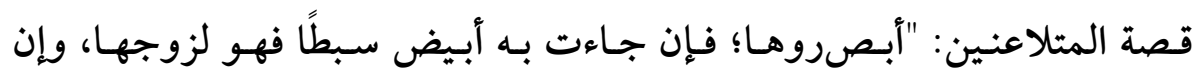

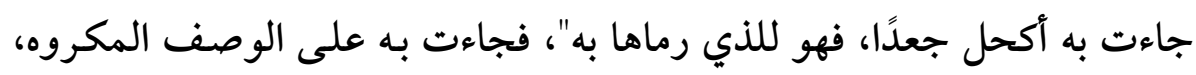

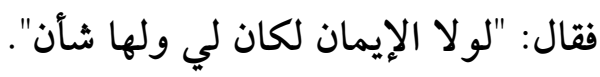

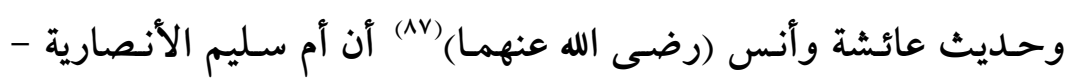

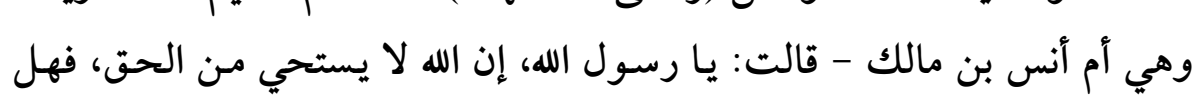

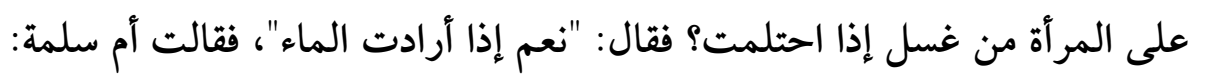

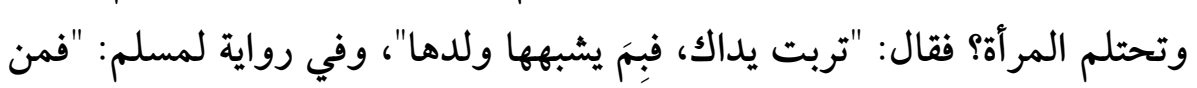

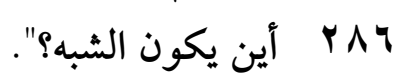

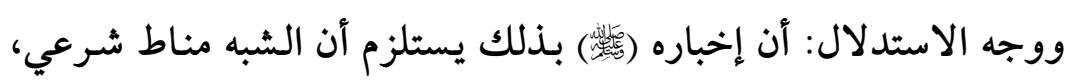

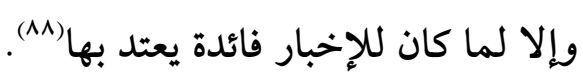

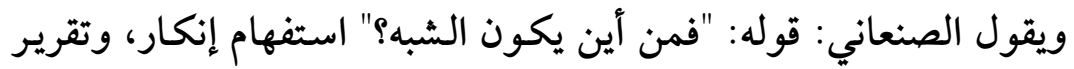

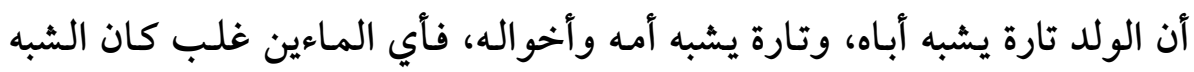

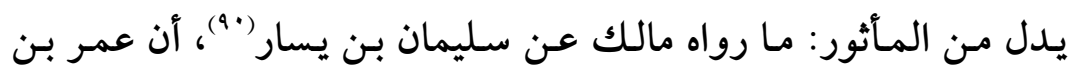
الخطاب (رضي الله عنه) كان يليط أولاد الجاهلية بمن ادَّعاهم في الإسلام، فأتى

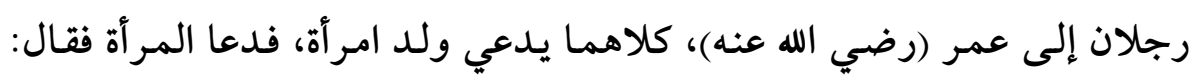

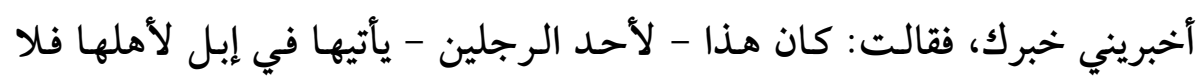

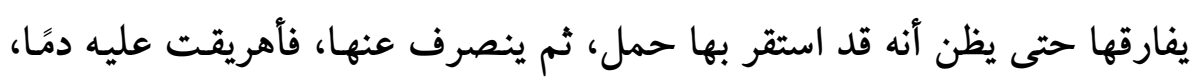




\section{إثبـات نسب اللقيط عز طريق البصمة الوراثية}

ثم خلف عليها هذا - يعني الآخر - فلا أدري من أيهما هو، فكبَّ القائف، فقال عمر للغلام: فإلى أيهما شئت فانتسب.

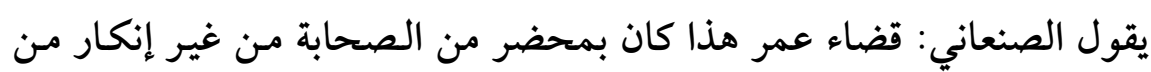
واحد منهم، فكان كالإجماع تقوى به أدلة القيافة. (11)

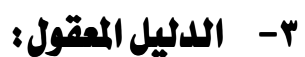

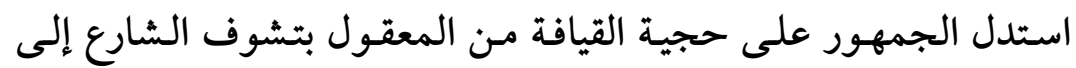

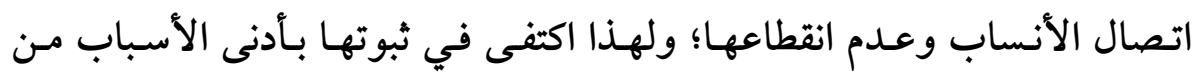

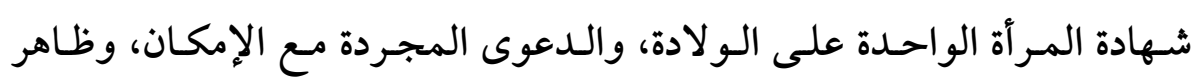

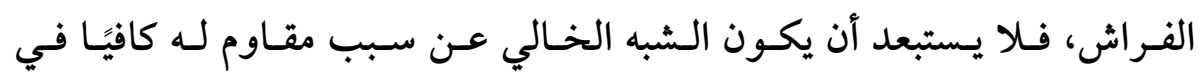

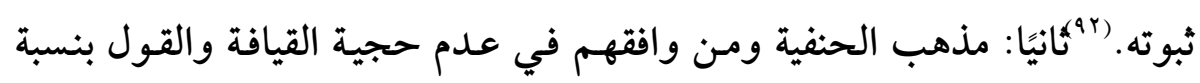

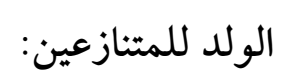

ذهب الحنفية والهادوية والشيعة الإمامية والشيعة الزيدية والإباضية إلى

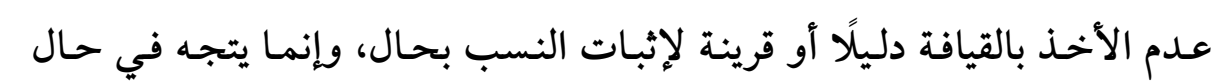

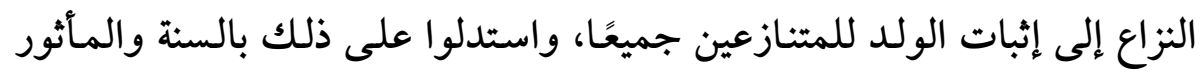
والمعقول. (ar)

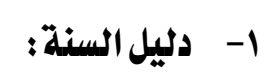

استدلوا من السنة بحديث عائشة (رضى الله عنها) قالت: (98 اختصم

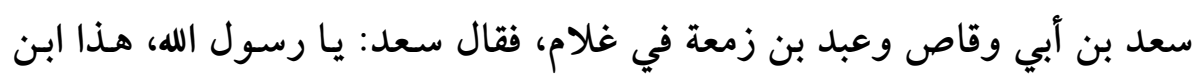

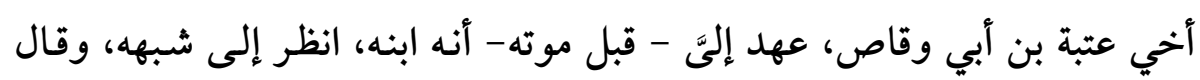

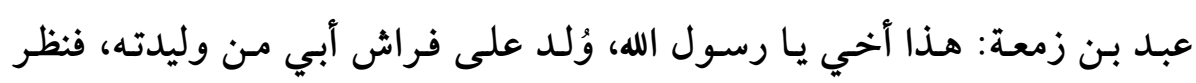

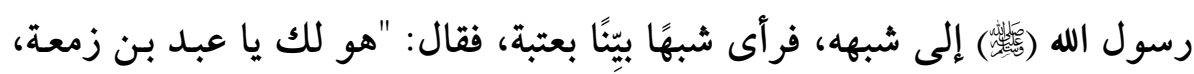
الولد للفراش، وللعاهر الحجر، واحتجبي منه يا سودة".

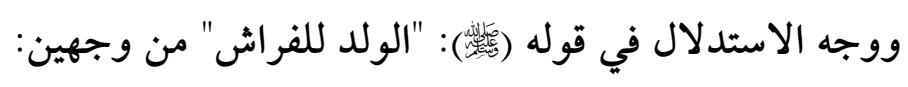




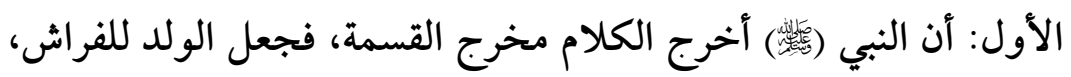

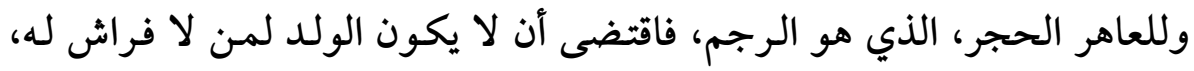

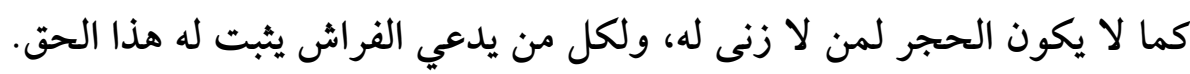

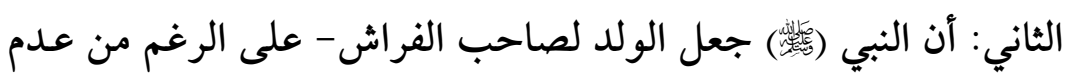

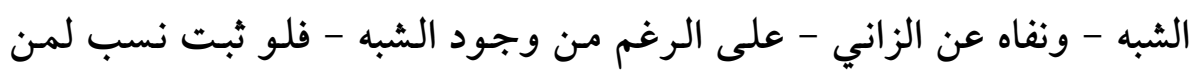

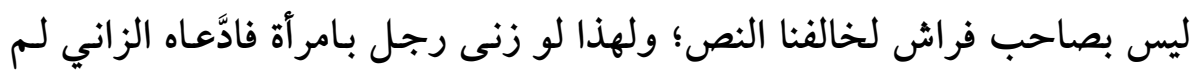

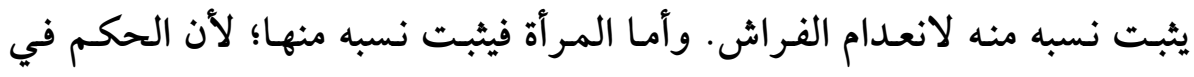

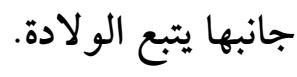

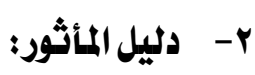

استدل الحنفية ومن وافقهم من المأثور بكتاب عمر (رضي الله عنه) إلى إنى

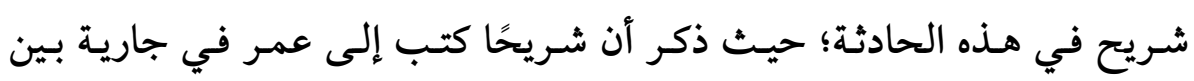

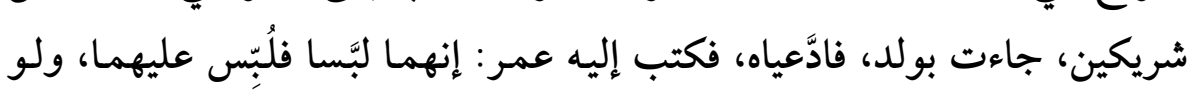

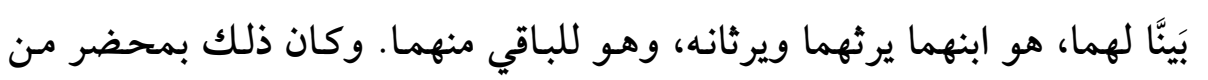

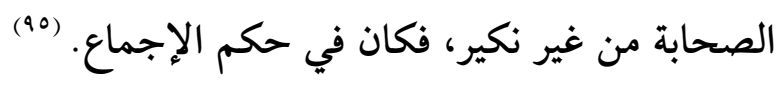

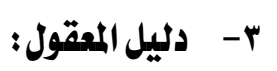

استدل الحنفية على عدم حجية القيافة بأكثر من وجه من المعقول، أذكر

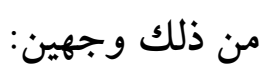
الأول: أن غاية القيافة إثبات المخلوقية من الماء، وإثبات النسب محصور في

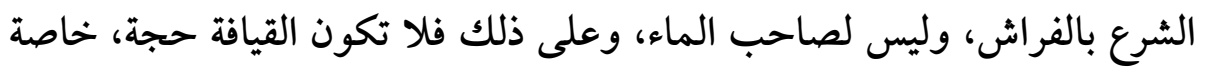
وأن القيافة تقوم على التخمين، وهي في حكم الكهانة.

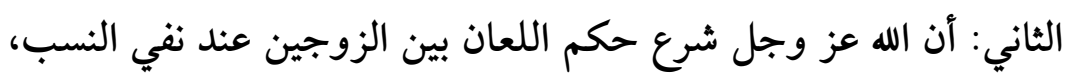

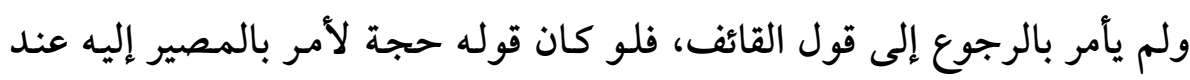
عدم الدليل ووجود الاشتباه. ثالثًا: القـول الراجح في القيافـة والنظرة التخريجية مـن المـذهبين للبصمة 


\section{إثيات نسب اللقيط عنطريق البصمة الوراثية}

بعد هذا العرض السابق لأقوال الفقهاء وأدلتهم في حجية القيافة في

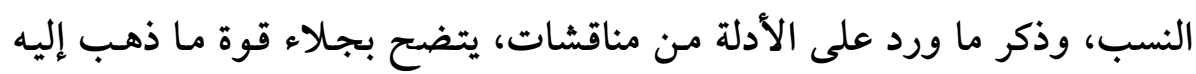

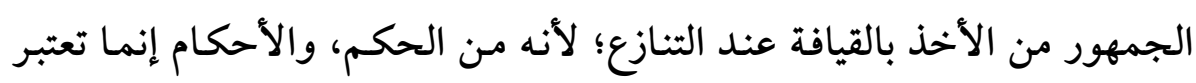
الظاهر، والله تعالى يتولى السرائر.

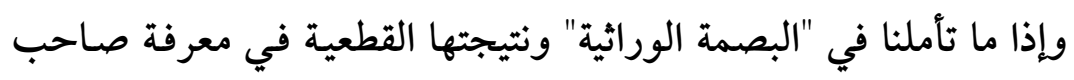

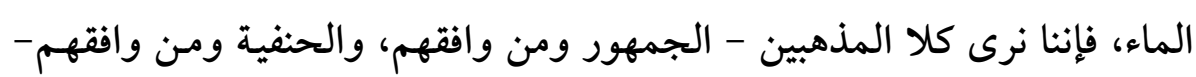

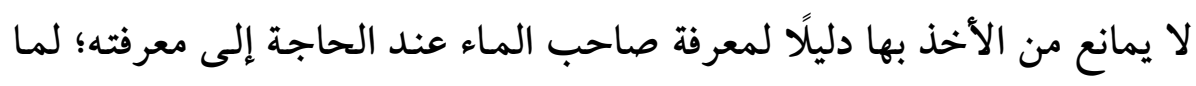

ا ـ. أن الجمهور أخـذوا بالقيافة مع ضعفها، فأولى بهم أن يقروا "البعمة

$$
\text { الوراثية" مع قوتها. }
$$

r. أن الحنفية امتنعوا عن الأخذ بالقيافة لأنهم حصروا أدلة إثبات النسب النبا

$$
\text { في الفراش الشرعي (النكاح والاستيلاد). }
$$

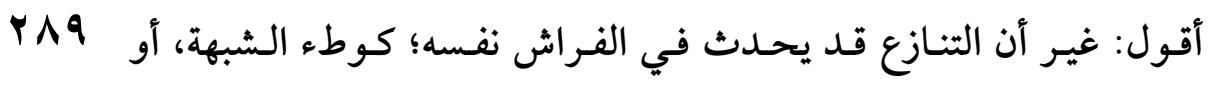

$$
\text { 高 }
$$

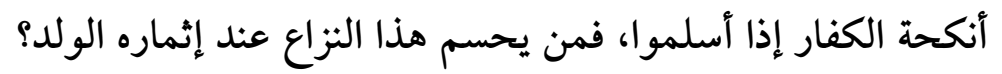

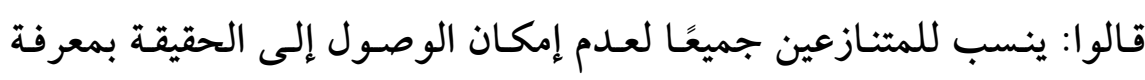

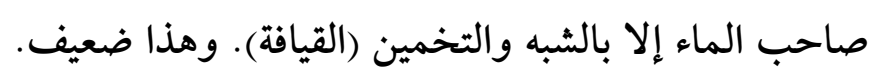

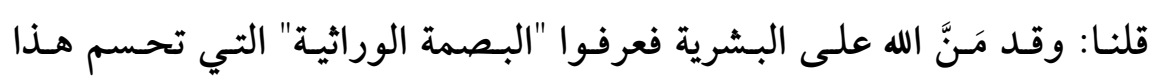

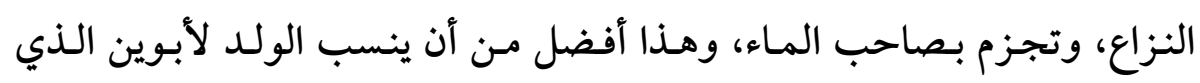

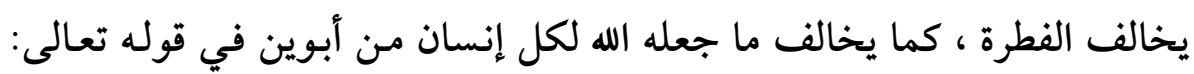

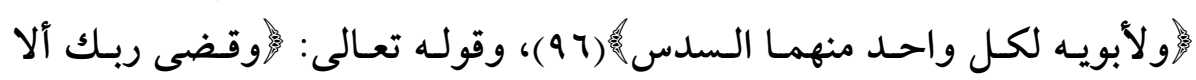
تعبدوا إلا إياه وبالو الدين إحسانًا (av) رابعًا: هل يفتح الفقه الإسلامي آفاقًا علمية جديدة بفتواه بتنسيب الولد إندان

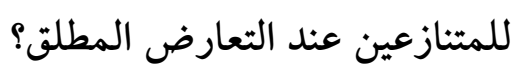


العلم الكوني يتطور في كل يوم، وما كان بالأمس علمًا ونظرية أصبح بعضه اليوم تخلفًا ورجعية.

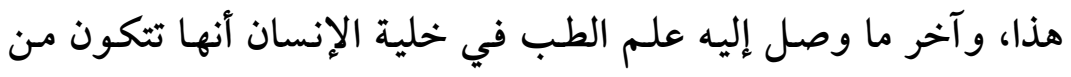

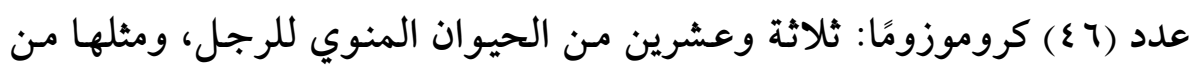

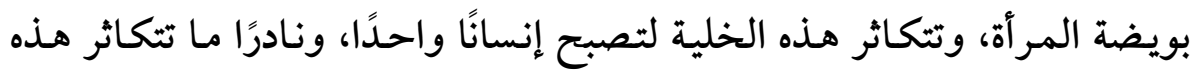
الخلية وتنقسم لخلق إنسانين توءم (متحد البويضة والحيوان المنوي).

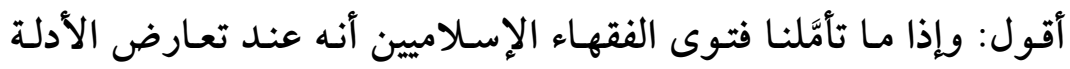

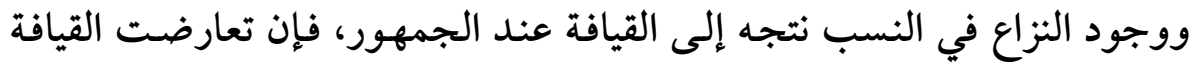

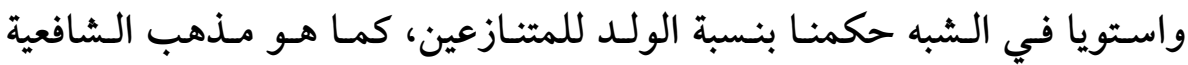

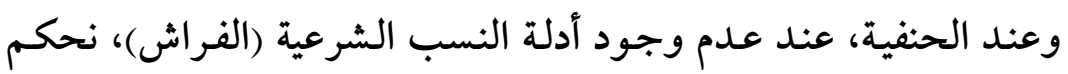
وبعض الحنابلة.

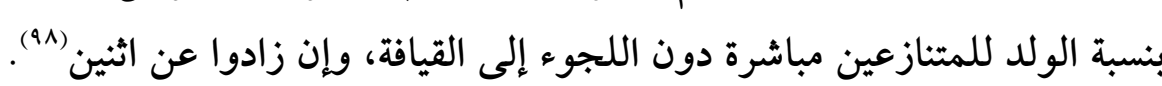

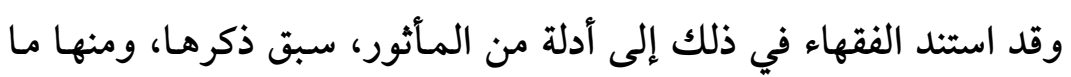

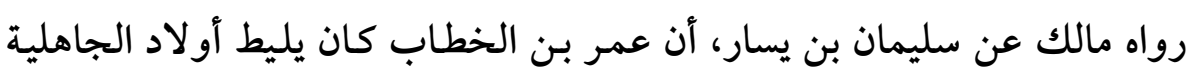

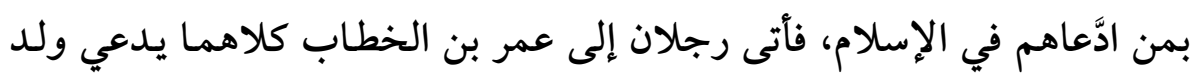
rq.

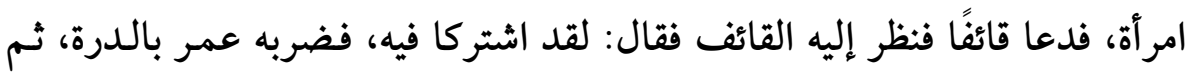

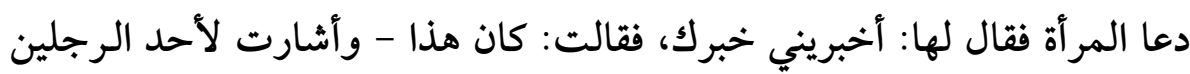

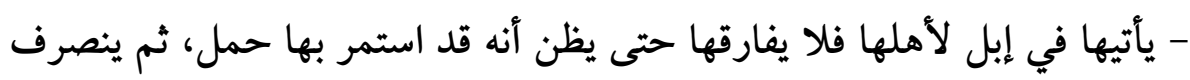

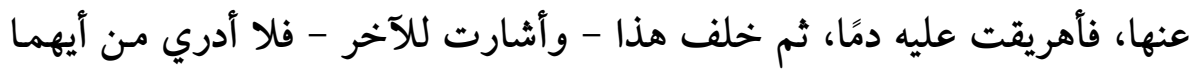
هو؟ فكبّر القائف لثبوت رؤيته.

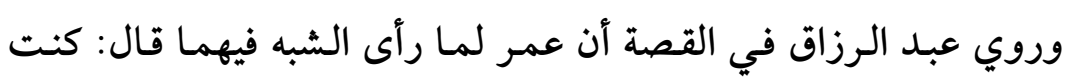

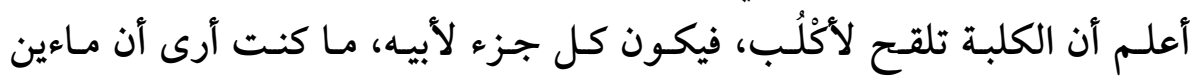

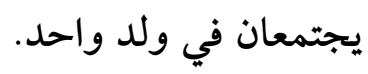


فما قولكم يا أصحاب علم الوراثة في تلك النوادر الخِلْقية التي لاحظها

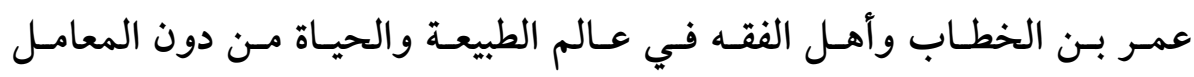
المجهزة.

\section{المبحث الرابع}

\section{القضاء الكمويتي وموقفه من البصمة الوراثية}

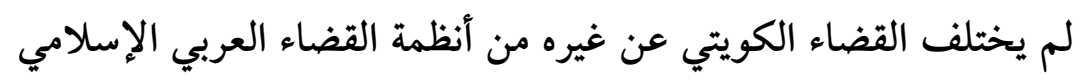

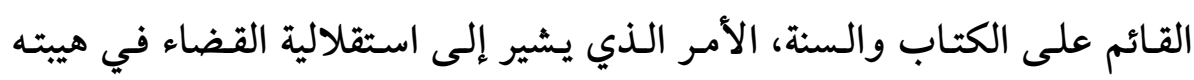

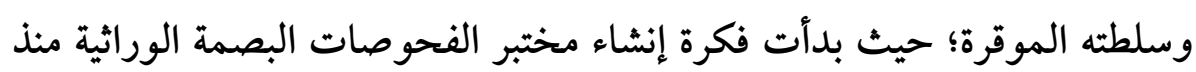

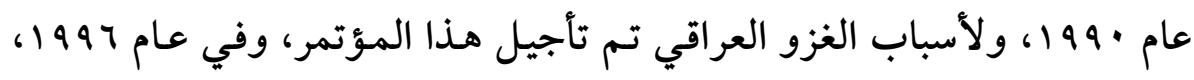

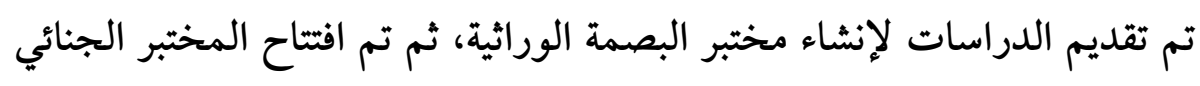

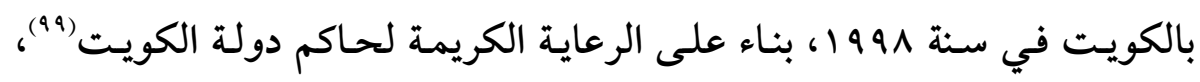

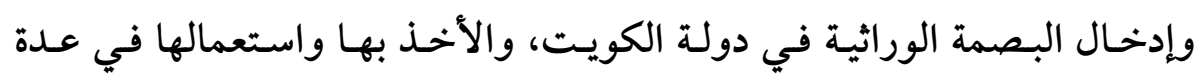
قضايا شرعية وجنائية.

$\overline{3}$

والجدير بالذكر أنه في دولة الكويت، وبعد أن شاع خبر البصمة الوراثية

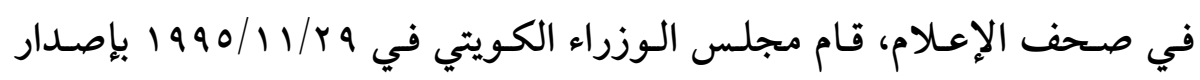

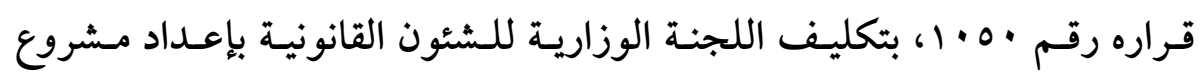

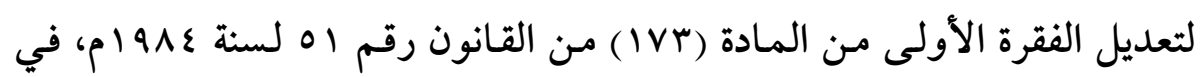

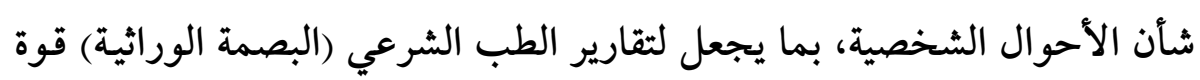
تدليلية يعتد بها في دعاوى إثبات النسب ونفيه.

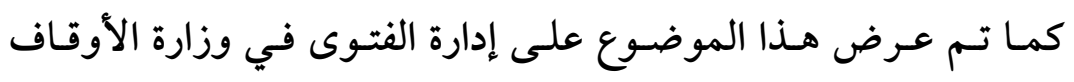

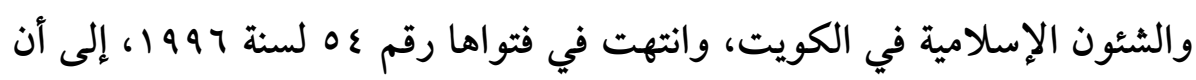

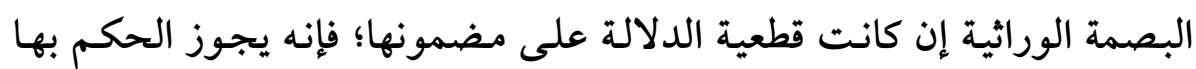

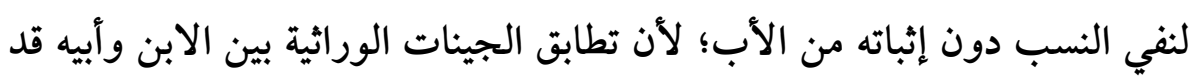

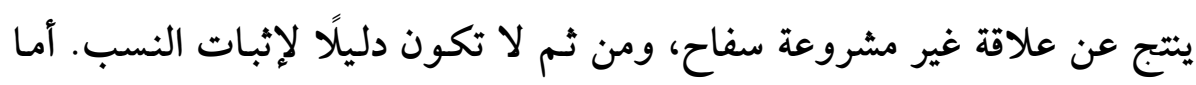


إذا لــم تكـن قطعيـة الدلالـة؛ فـلا يجـوز الأخـذ بهـا في إثبـات النسب ولا في نفيه. (1..)

غير أن قرار إدارة الفتوى بوزارة الأوقاف غير ملزم لأهل القضاء الذين

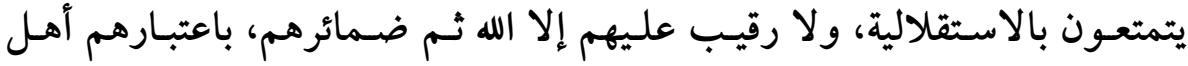

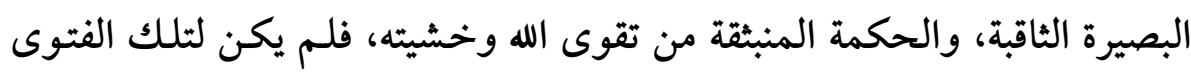

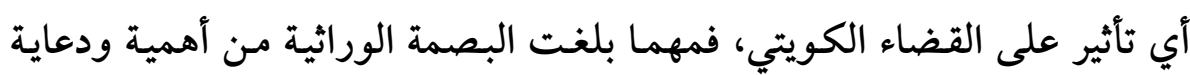

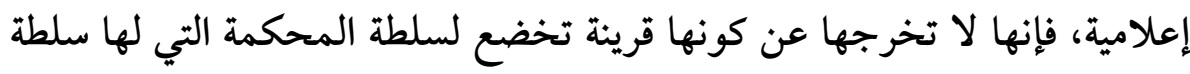
تقدير قوة العناصر التدليلية في القضايا الماثلة أمامها. محاكم الكويت وموقفها من البصمة الوراثية:

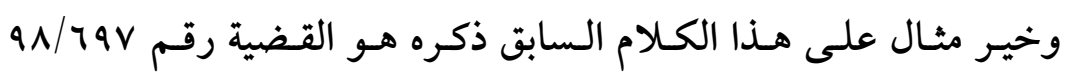

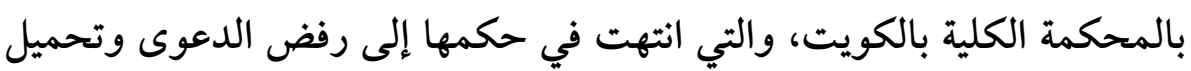

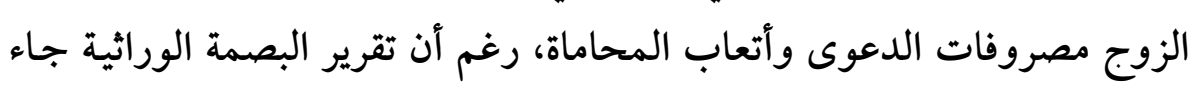

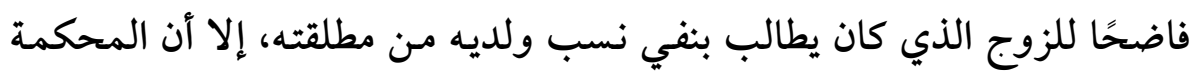
استبعدت هذا الثقرير ولم تلتفت إليه.

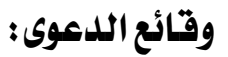

أ. المدعي هو الزوج ضد المدعى عليهم؛ الزوجة "المطلقة"، ووكيل وزارة

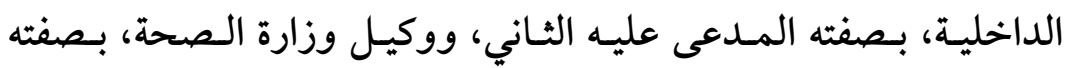

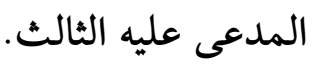

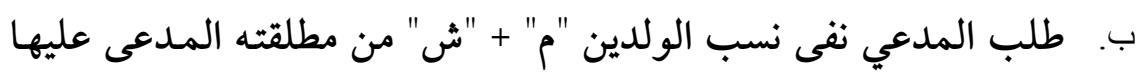
الأولى، وذلك في مواجهة المدعى عليهما الثاني والثالث.

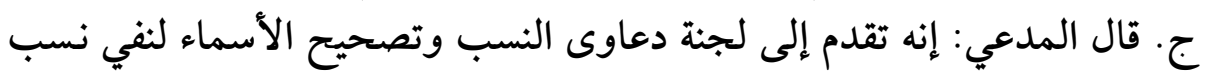

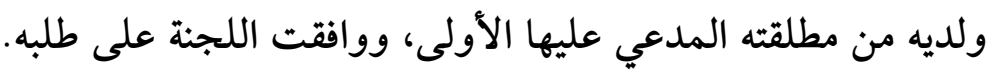

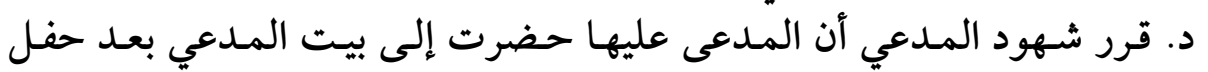

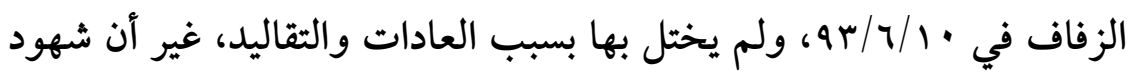

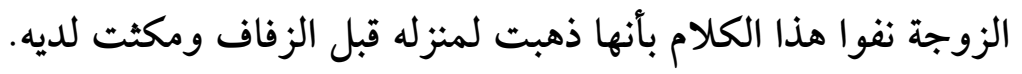




\section{إثيات نسب اللقيط عنطريق البصمة الوراثية}

هـ. جاء بتقرير البصمة الوراثية "أنه طبقًا لأسس علم الوراثة تبين أنه يستبعد أن

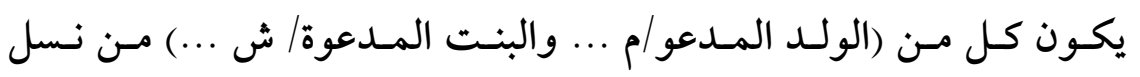

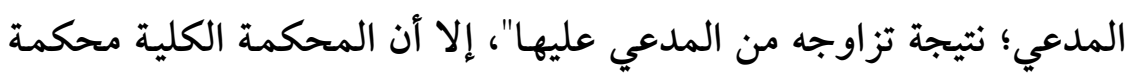

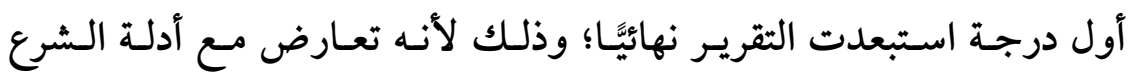

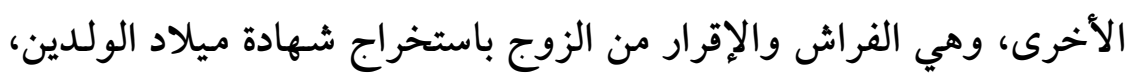

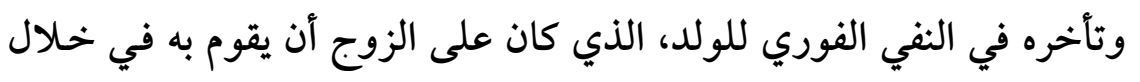

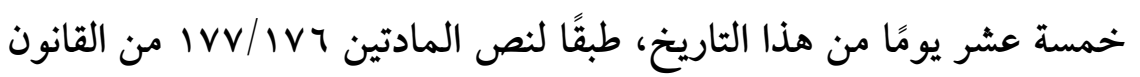
رقم 10/ 10 في شأن الأحوال الشخصية.

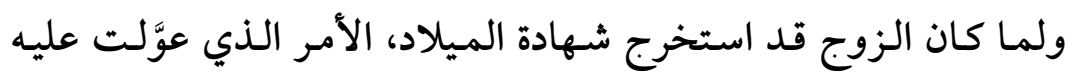

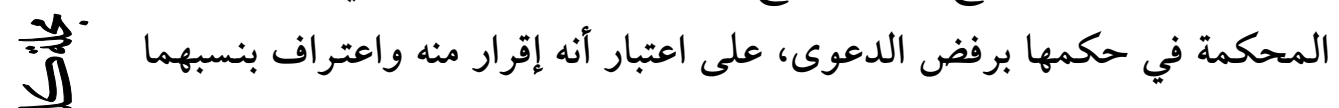

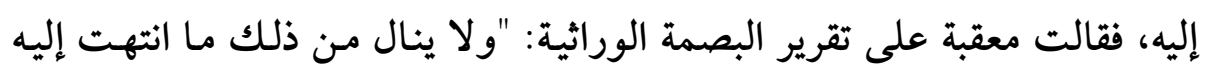

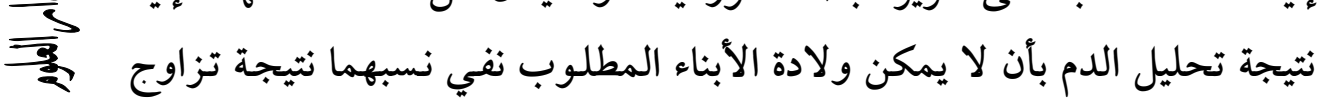

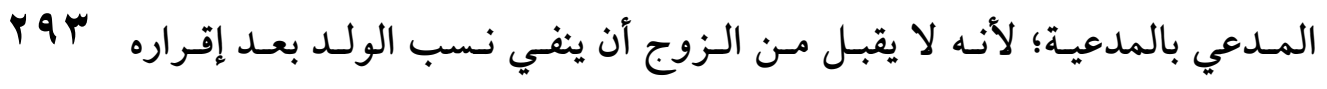

هذا وقد شق هذا الحكم الأول طريقه إلى محكمة الاستئناف، فاستأنفه

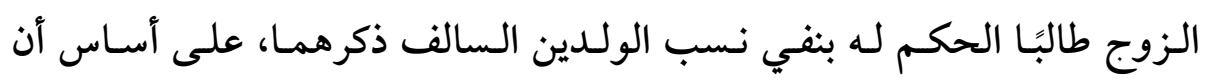

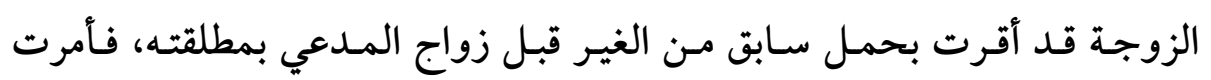

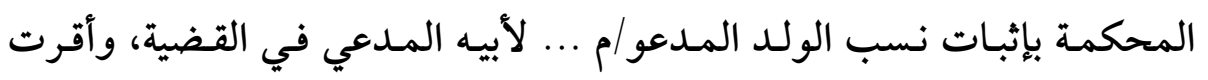

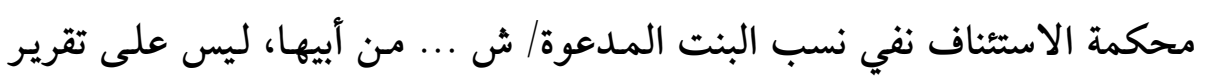

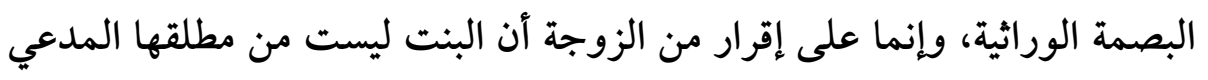

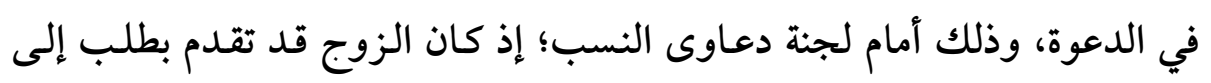

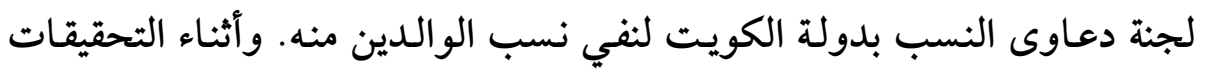

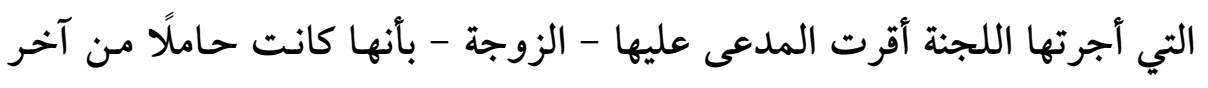

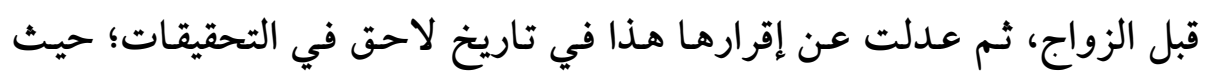

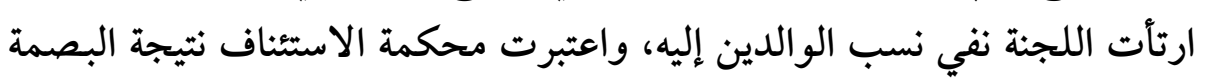


الوراثية قرينة على اعتراف الزوجة بالزنا أمام لجنة دعاوى النسب. وأما الولد

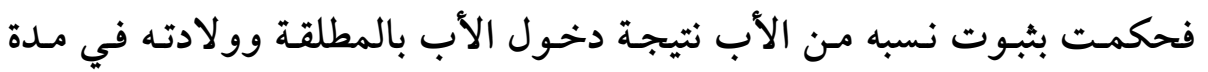

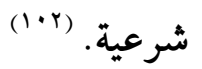
غير أن قرار محكمة الاستئناف هذا، والقاضي بنفي نسب البنت من أبيها

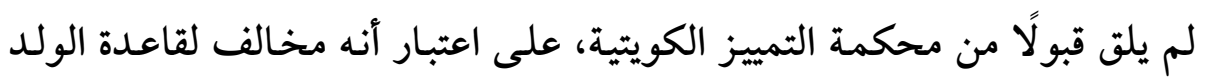

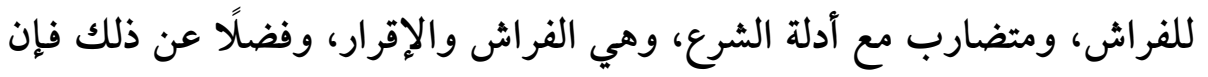

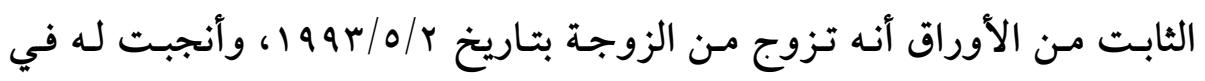

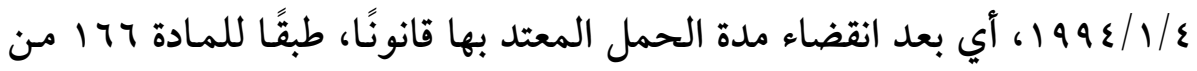

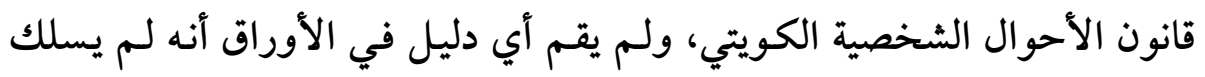

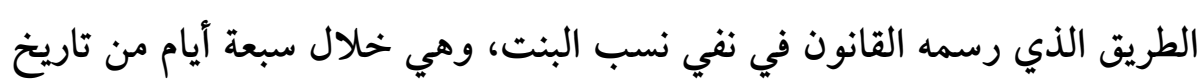

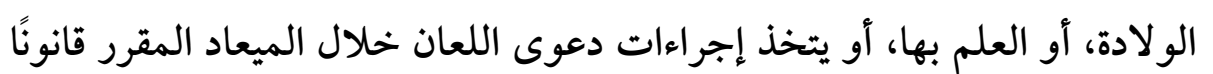

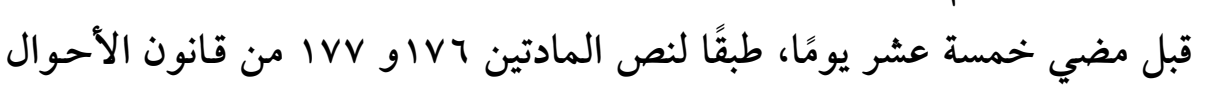

بالرغم من أنه لم ينازع في تحقق علمه بتاريخ ميلادها، فإن دعواه في ب الشخصية الكويتي.

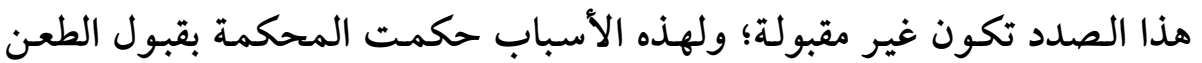
w

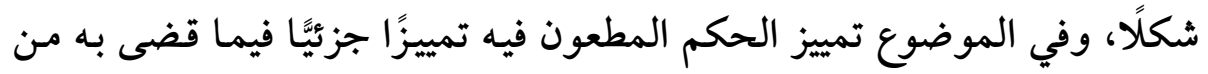

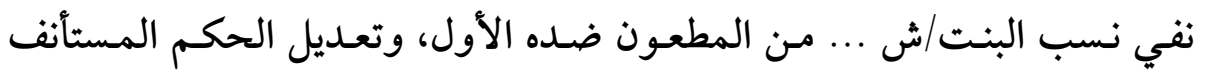

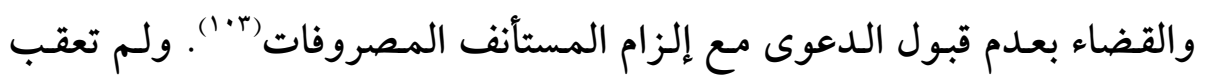
محكمة التمييز الكويتية على تقرير البصمة الوراثية.

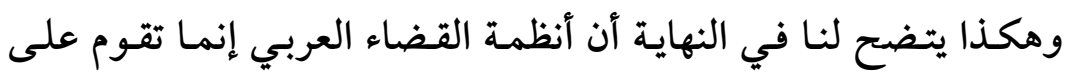
الجزم واليقين، ولا تقوم على مجرد الظنون والاحتمالات.

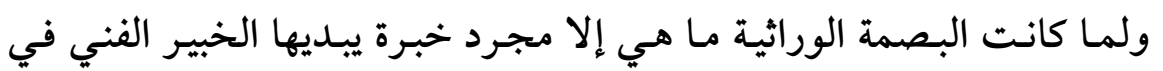

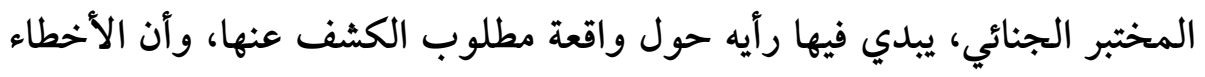

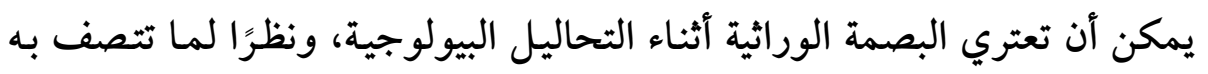

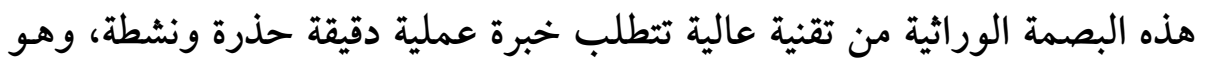




\section{إثبـات نسب اللقيط عز طريق البصمة الوراثية}

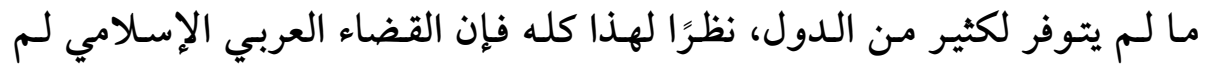

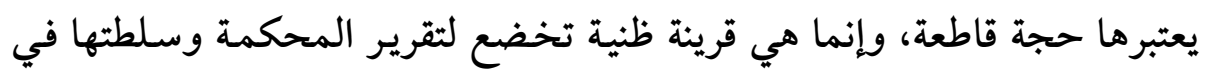
استخلاص الوقائع وتقدير أدلة الدعوى المطروحة فرية أمامها.

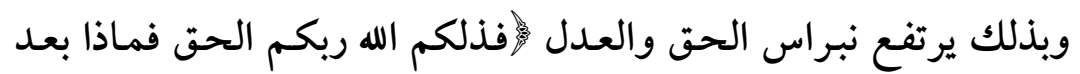

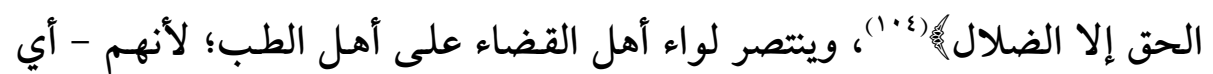

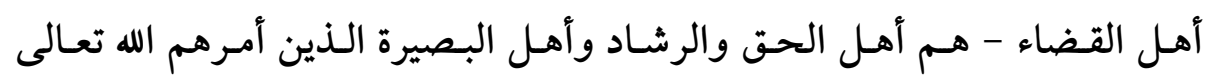

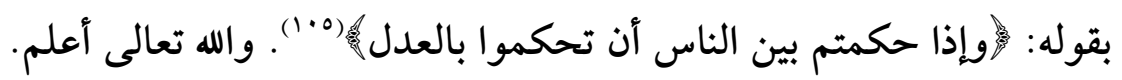

\section{خاتقة البحث}

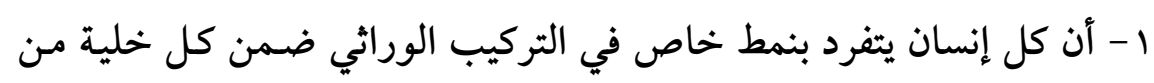

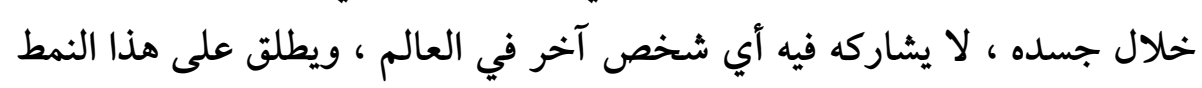

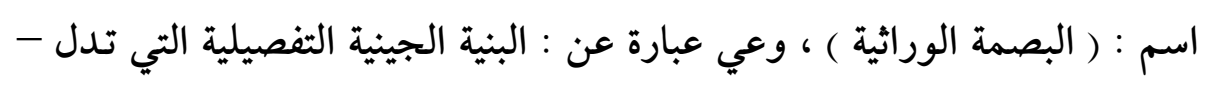
عند ذوي الاختصاص - على هوية كل فرد بعينة .

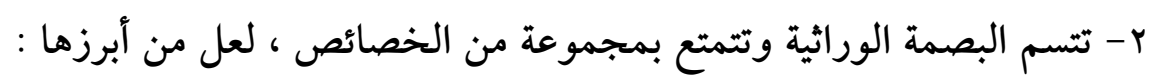

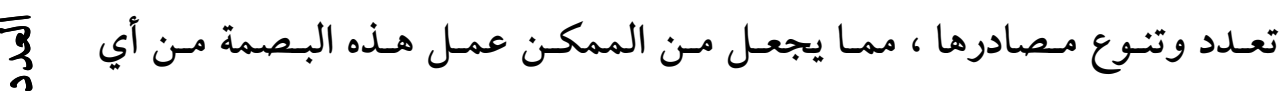

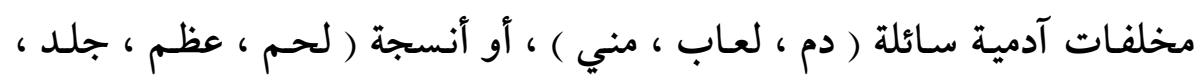

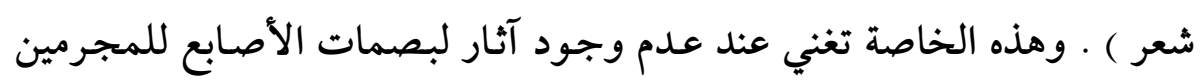

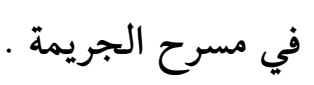

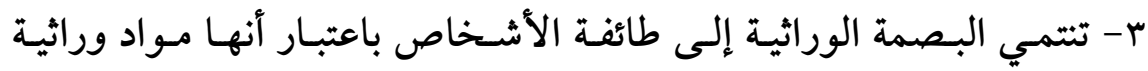

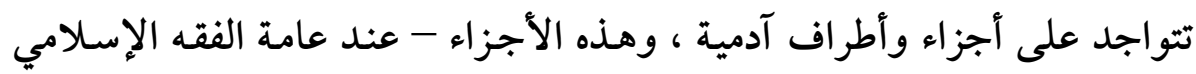

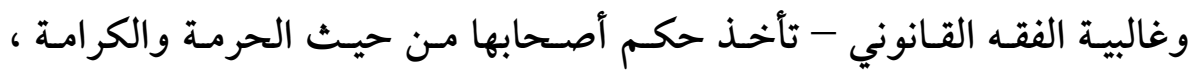

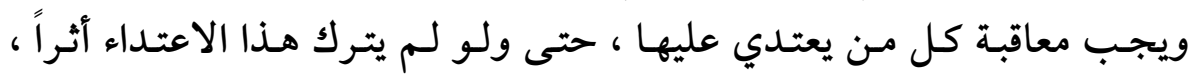

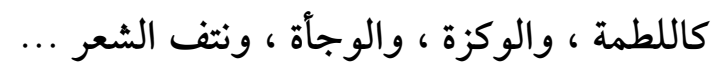

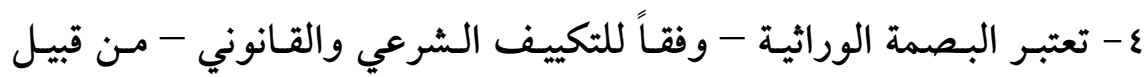
القرائن الفعلية أو القضائية ، أو ما يطلق عليه الأدلة المادية أو العلمية ، وتأخدـ حكمها وتنزل منزلتها . 
ه - تتفق القوانين الوضعية - من حيث الجملة - وكذلك القضاء الوضعي ،

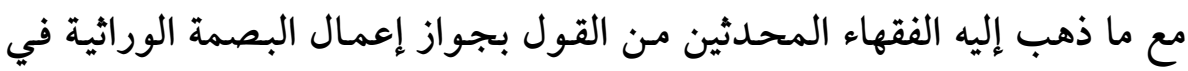

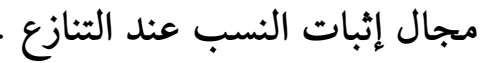
1- لا يجوز استخدام البصمة الوراثية بهدف التأكد من صحة الأنساب الثابتة،

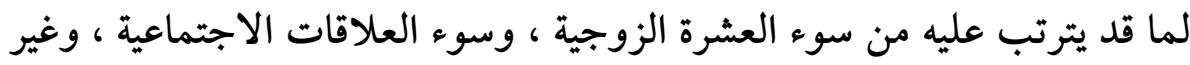
ذلك من مفاسد كثيرة .

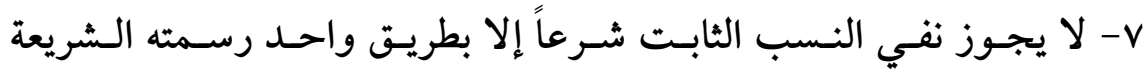

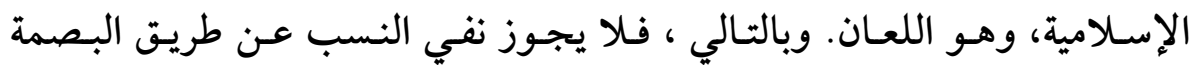
الوراثية أو غيرها من الوسائل الأخرى.

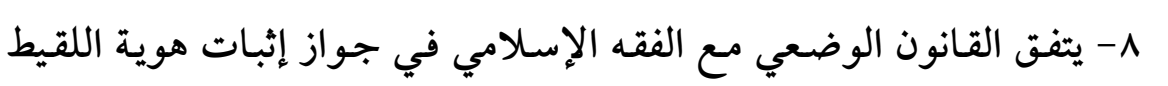

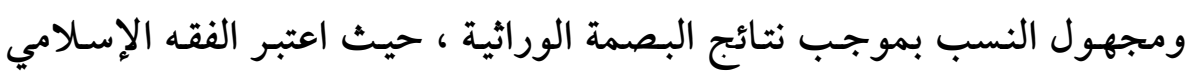

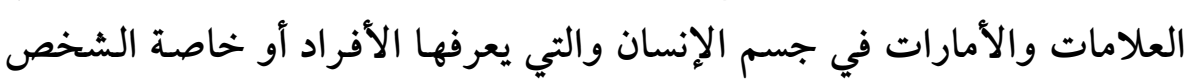

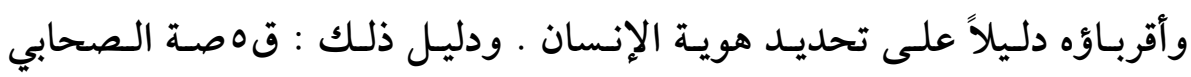

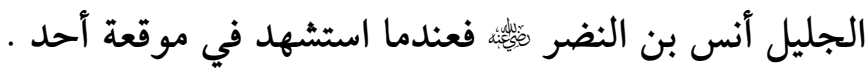

\section{المصادروالمراجع}

1. المعجـم المفهرس لألفاظ القـرآن الكريم بحاشية المصحف الشريف.

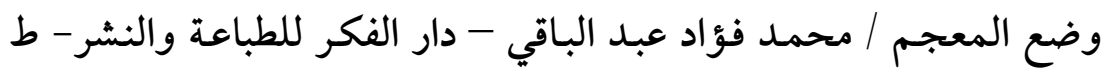

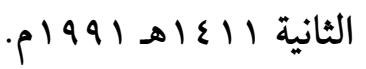

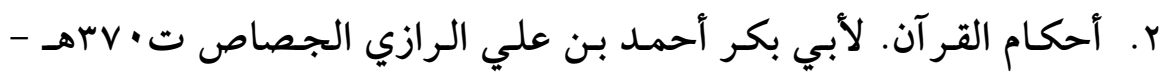

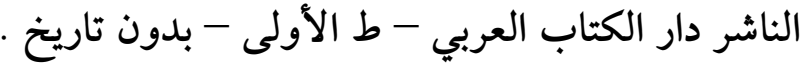

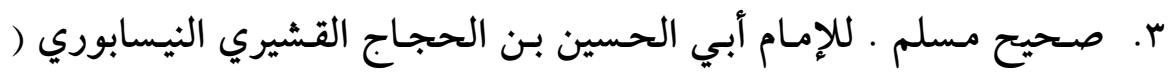

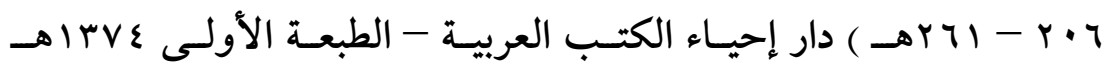

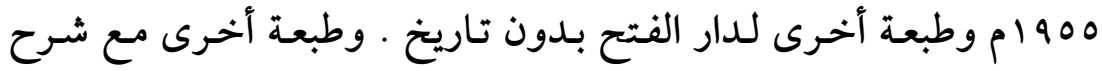

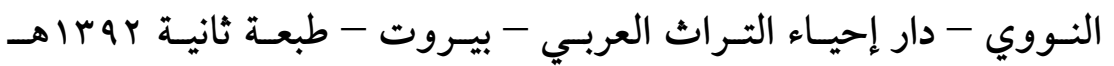




\section{إثبيات نسب اللقيط عزطريق البيمة الوراثية}

ع. فيض القدير شـرح الجامع الصغير ـ للمناوي ، عبد الرؤوف محمد تاج

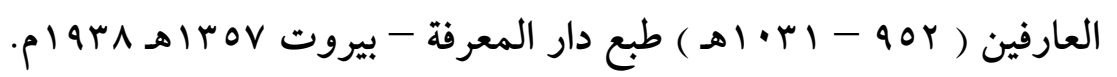

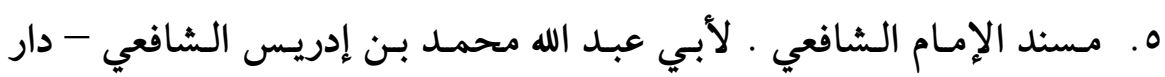

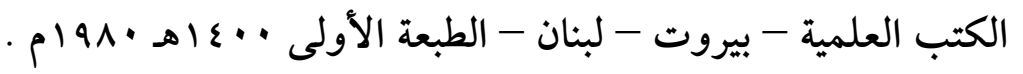

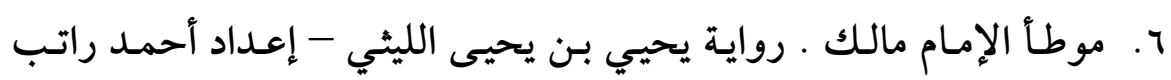

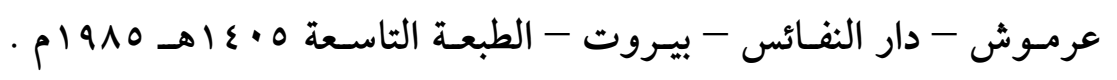

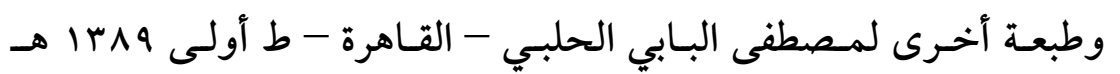

. $19 \mathrm{~V}$.

V. الاختيار لتعليل المختار . للشيخ عبد الله بن محمود بن مودود الموصلي

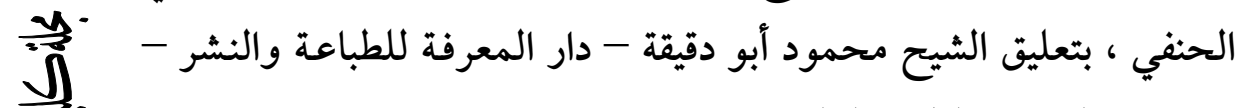

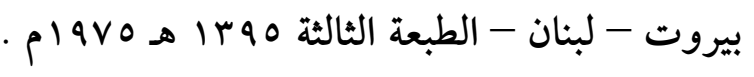

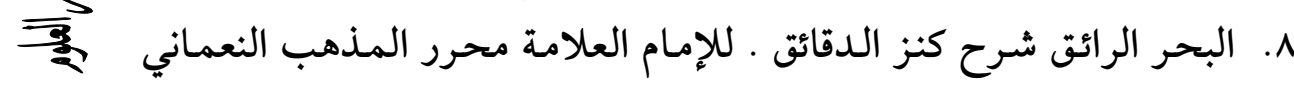

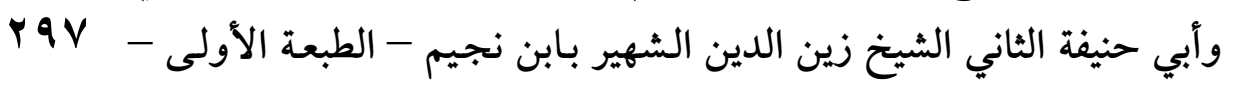

亨 المطبعة العلمية - القاهرة - بدون تاريخ

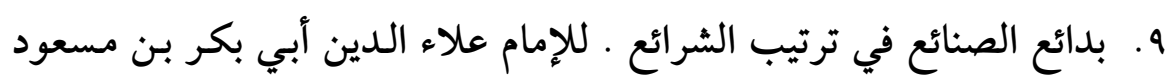

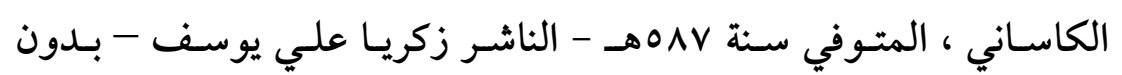
تاريخ

• 1 . تبيين الحقائق شرح كنز الدقائق . للعلامة فخر الدين عثمان بن علي

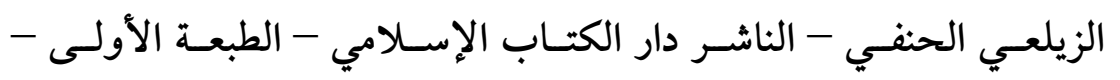

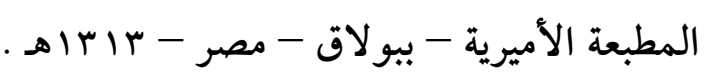

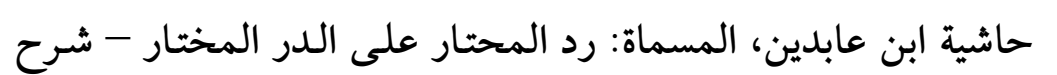

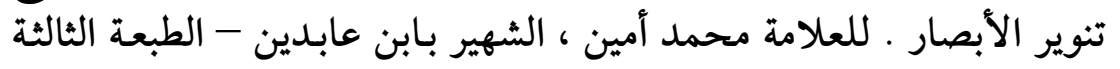

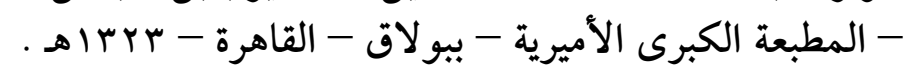

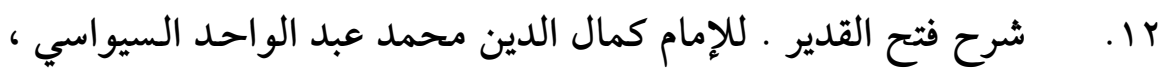

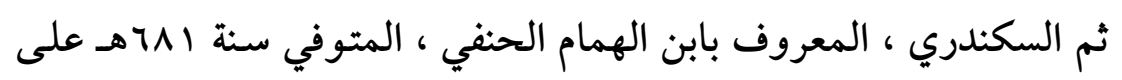


الهداية شرح بداية المبتدى لشيخ الإسلام برهان الدين على بن أبي بكر

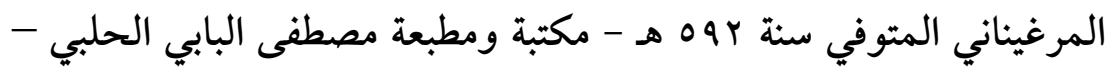

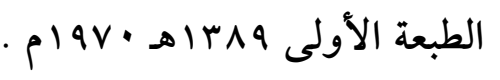

rا. . المبسوط ـ لشمس الدين السرخسي - أول طبعة ظهرت على ملى وجهـ

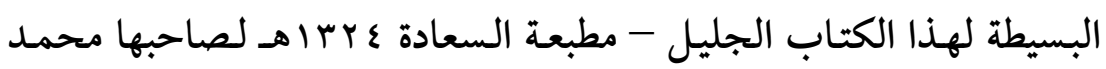

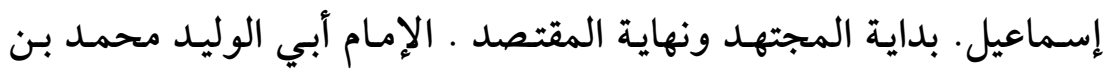

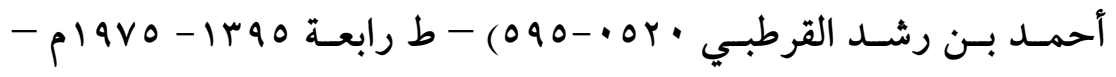

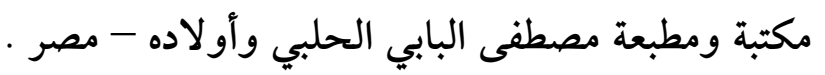

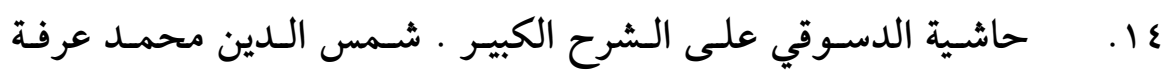

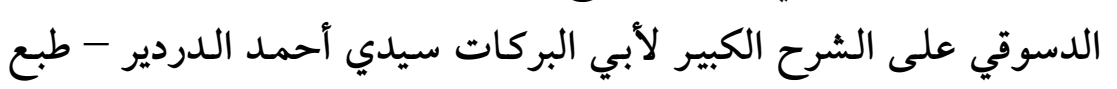
بدار إحياء الكتب العربية - عيسى البابي الحلبي وشركاه.

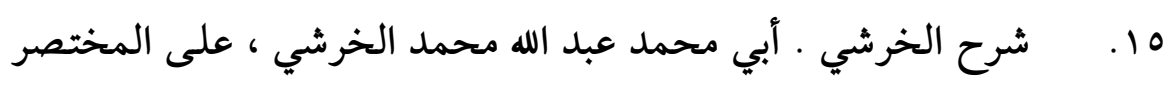

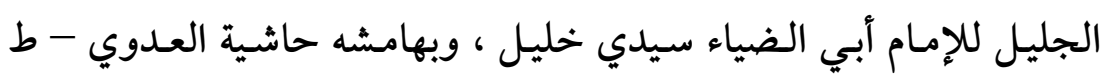

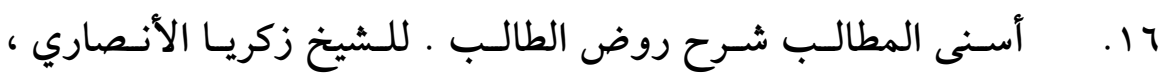

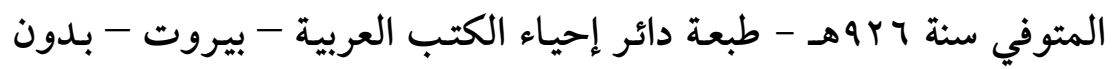
تاريخ. وطبعة أخرى للمكتبة الإسلامية - بدون تاريخ.

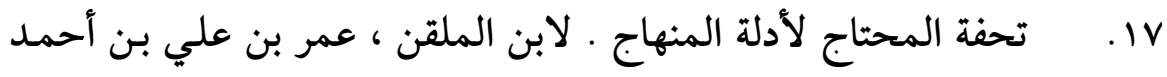

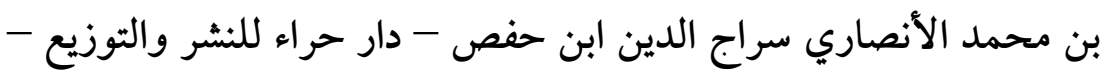

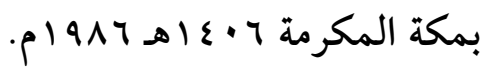

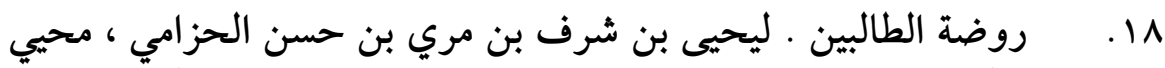

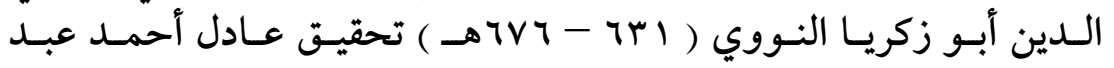

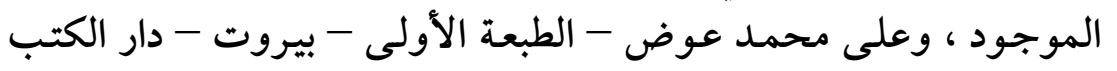

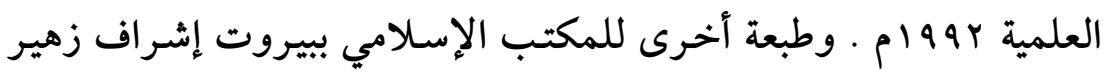

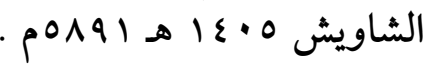




\section{إثيات نسب اللقيط عنطريق البصمة الوراثية}

19 1. مغني المحتاج إلى معرفة ألفاظ المنهاج ـ للشيخ محمد الشربيني

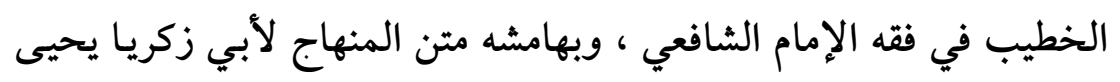

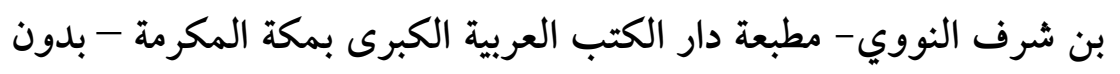

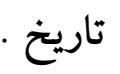

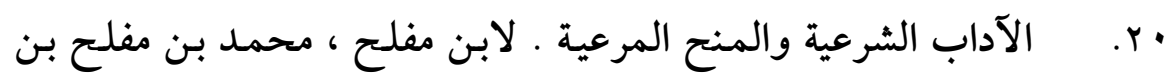

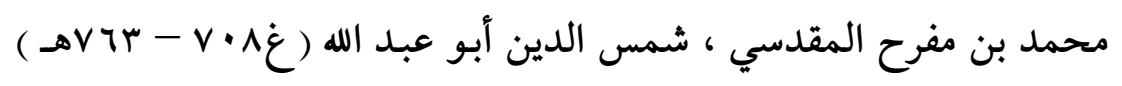

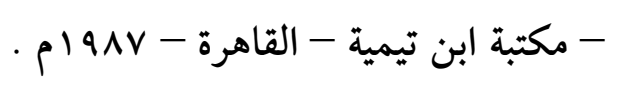

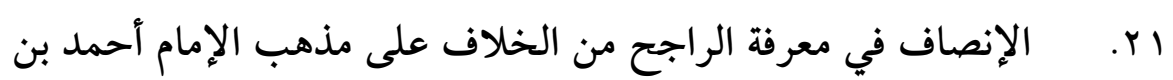

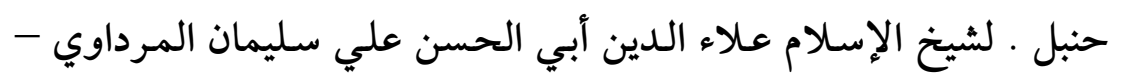

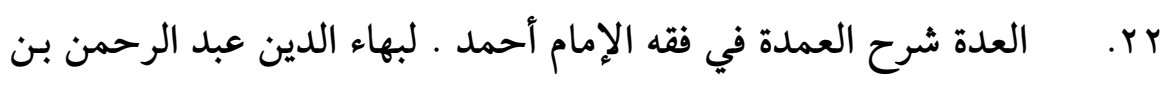

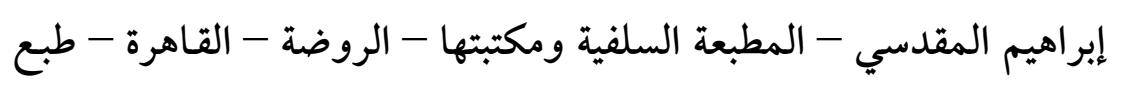

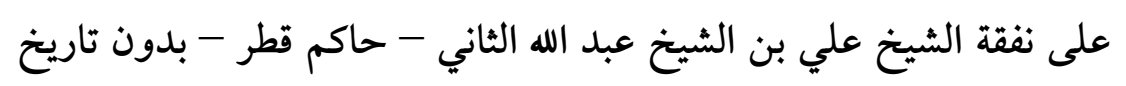

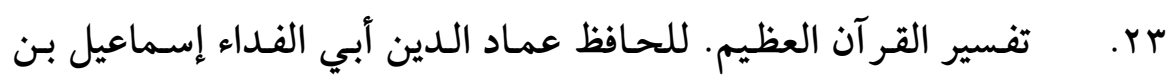

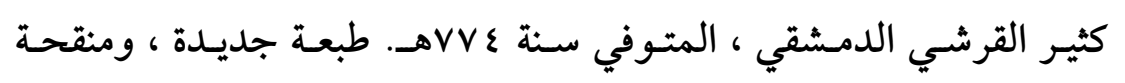

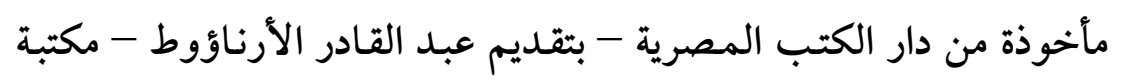

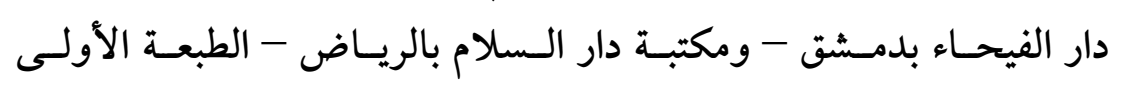

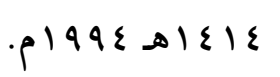

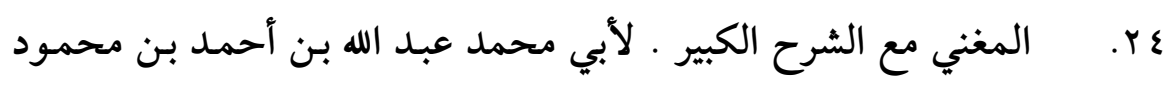

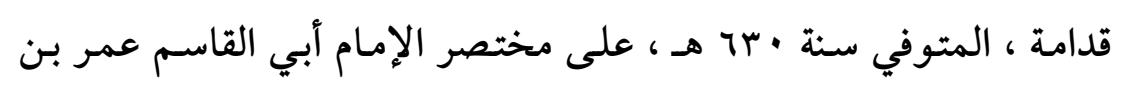

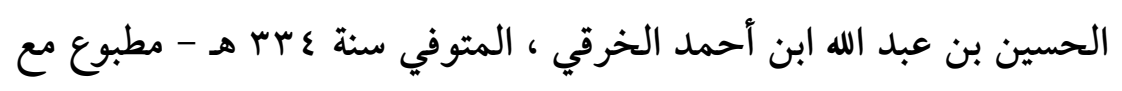

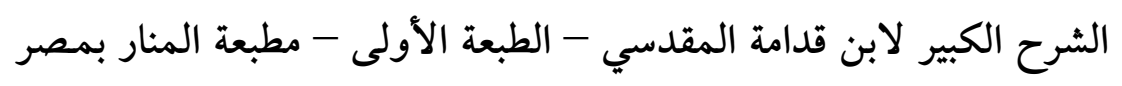

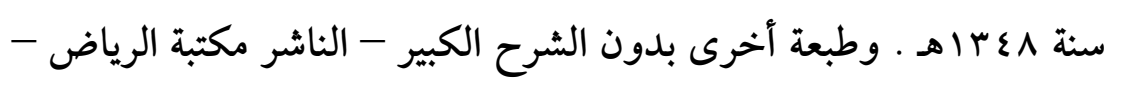




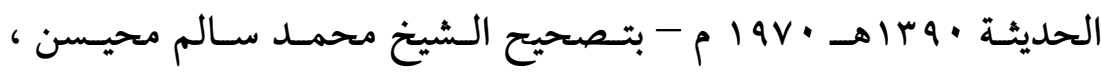
والشيخ شعبان محمد إسماعيل .

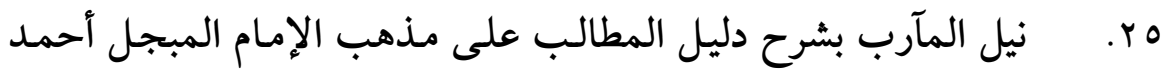

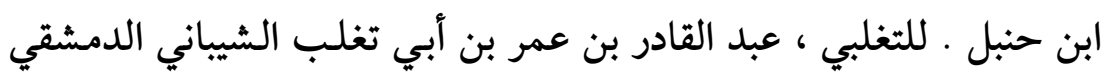

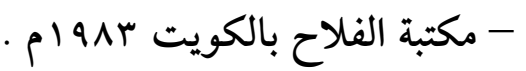

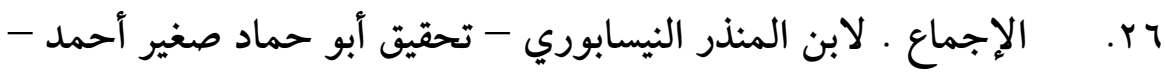

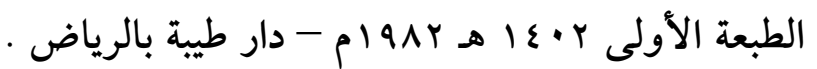
rV

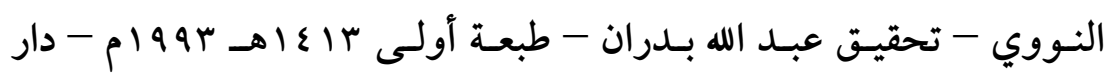

$$
\text { الخير للطباعة والنشر - بيروت. }
$$

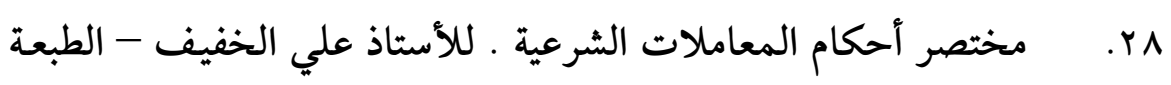

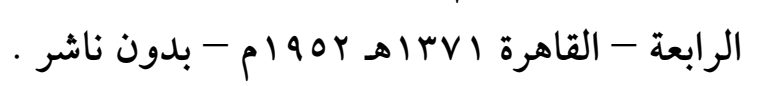

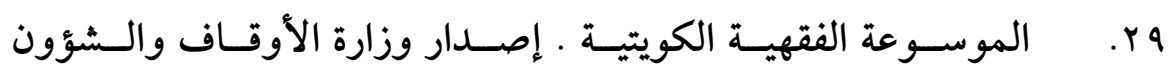

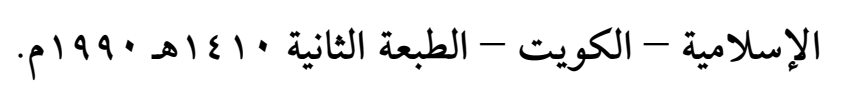

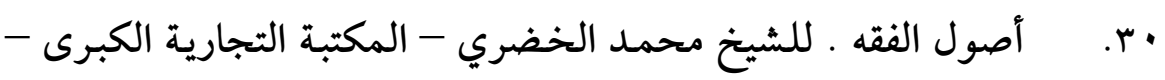

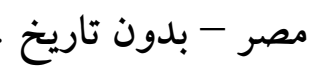

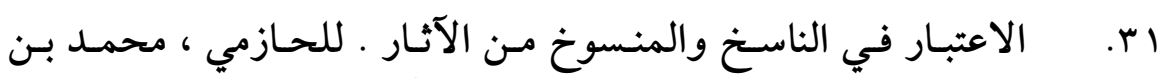

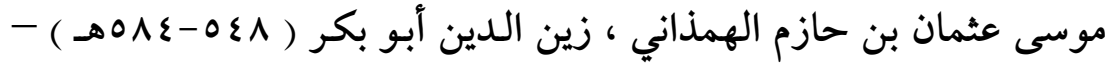

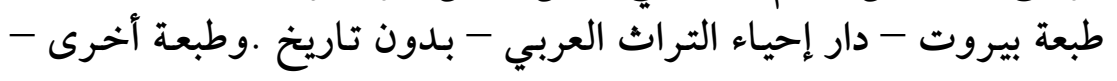

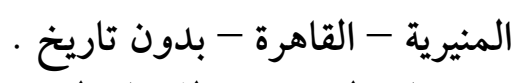

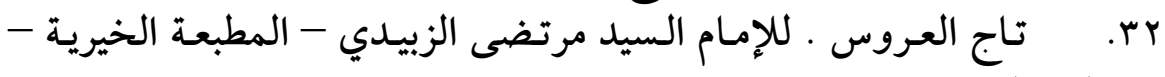

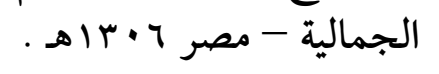

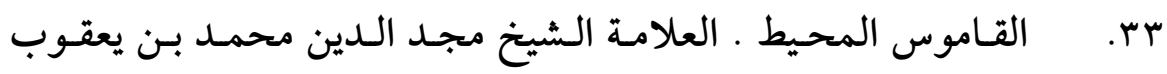

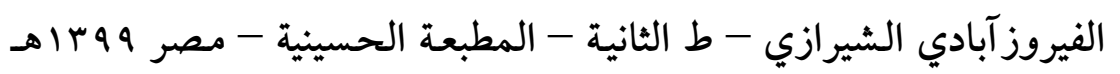




\section{إثيات نسب اللقيط عنطريق البصمة الوراثية}

ع ب. بلـوغ المـرام مـن جمـع أدلـة الأحكـام ـ للحـافظ أبي الفـضل شهاب

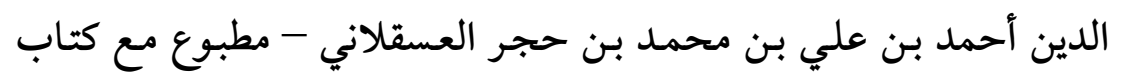

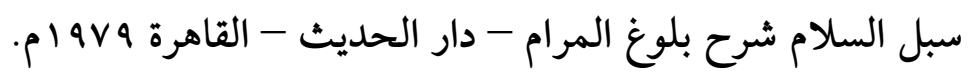

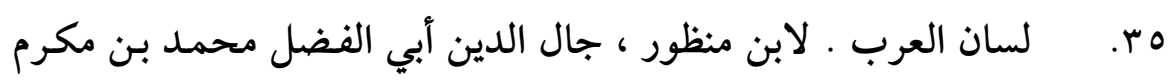

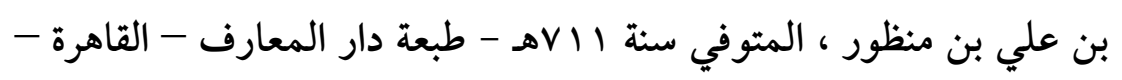
طبعة جديدة محققة ومشكولة .

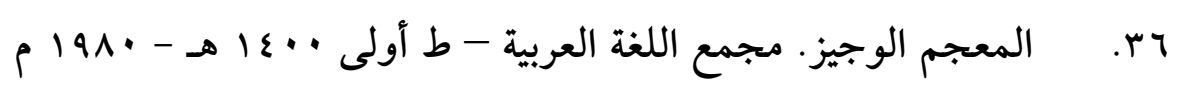
- مطابع شركة الإعلانات الشرقية - دار التحرير للطباعة والنشر . rV والمستشرقين. لخير الدين الزركلي - طبعة بيروت - دار العلم للملايين

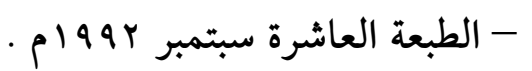

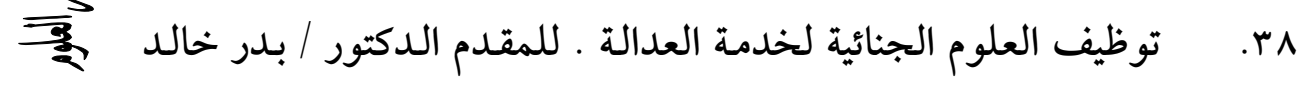

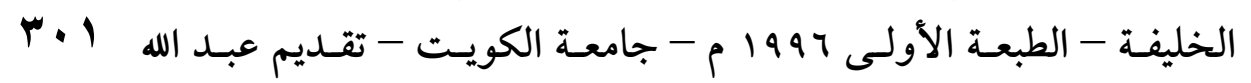

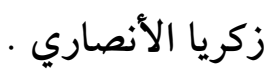
ه r. الجنسية الكويتية - دراسة للنظرية العامة للجنسية وللمرسوم الأميري رقم 10 لسنة 1909 م بشأن الجنسية الكويتية وتعديلاته .

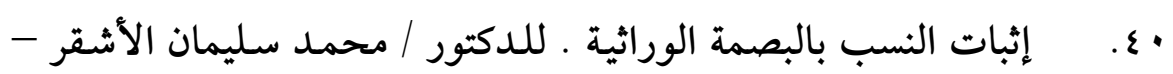

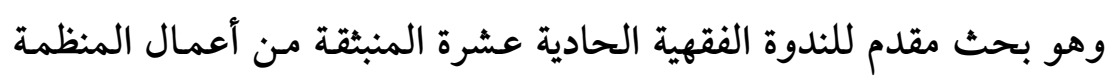

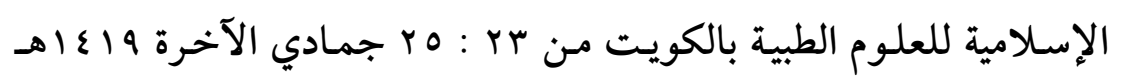

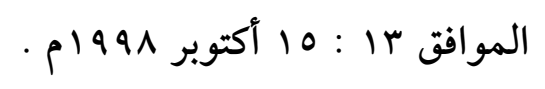
اعـ. إثبات النسب بالبصمة الوراثية ـ للشيخ محمد مختار السلامي - وهو

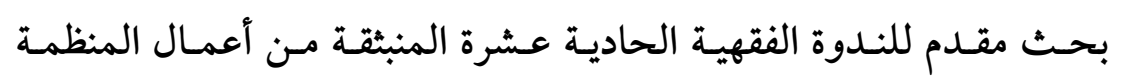

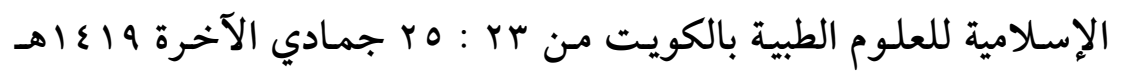

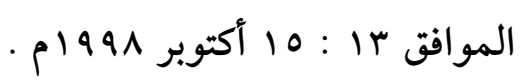


ץع . البصمة الوراثية ومدى حجيتها في إثبات النسب ـ للدكتور / سعد

العنزي ، وهو بحث مقدم للندوة الفقهية الحادية عشرة المنبثقة من أعمال

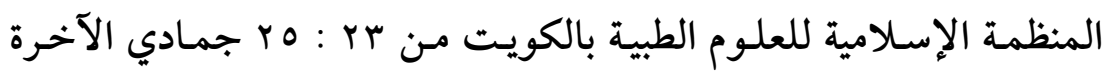

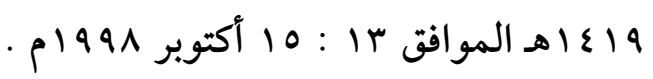

بع. دور البصمة الوراثية ـ للدكتورة / صديقة العوضي - وهو بحث مقدم

للندوة الفقهية الحادية عشرة المنبثقة من أعمال المنظمة الإسلامية للعلوم

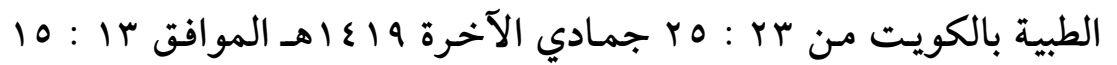

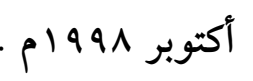

ع ـ . ملخصات لبحوث إليك جفري عن مراحل اكتشافه للبصمة الوراثية

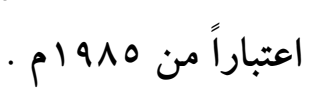

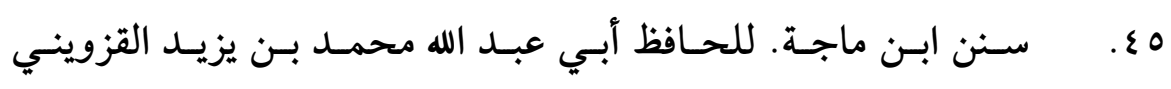

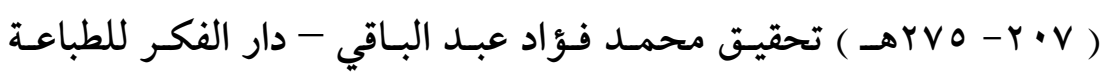

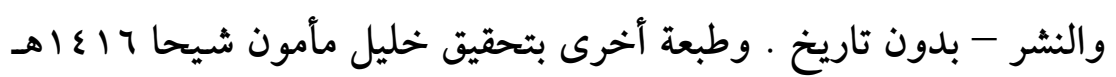

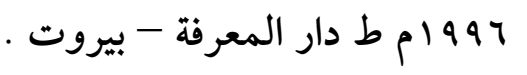

حـ. سنن أبي داود ـ للحافظ أبي داود سليمان بـ الاشعث السجستاني

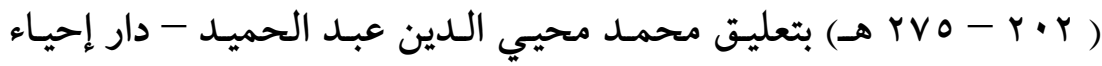
التراث العربي - بدون تاريخ .وطبعة أخرى بتحقيق عزت عبيد دعاس -

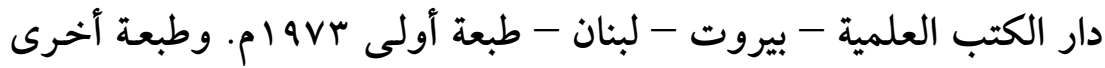

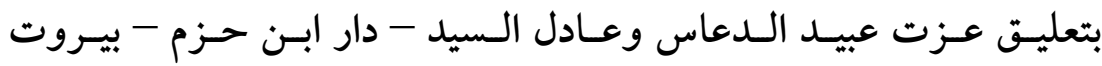

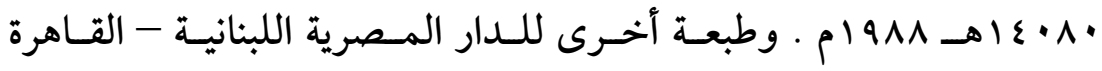

$$
\text { · } 1991-ه 1 \varepsilon \cdot \Lambda
$$

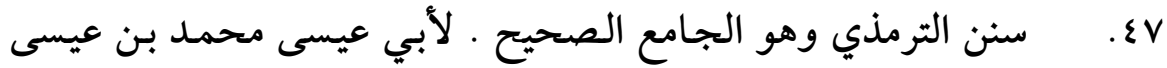

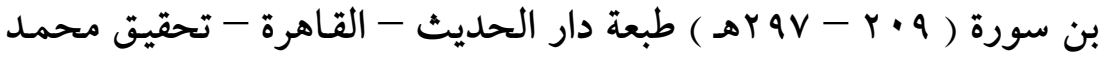

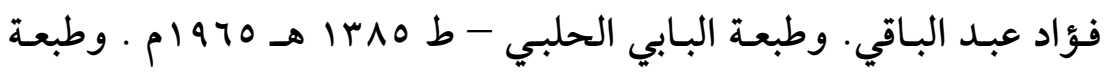




\section{إثيات نسب اللقيط عنطريق البصمة الوراثية}

أخرى بشرح ابن العربي المالكي - دار الكتاب العربي - بيروت - بدون

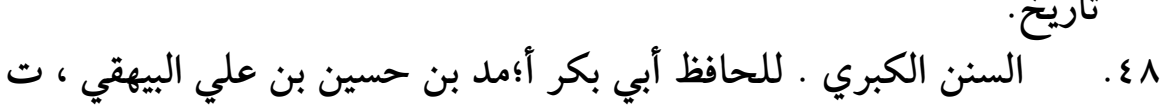

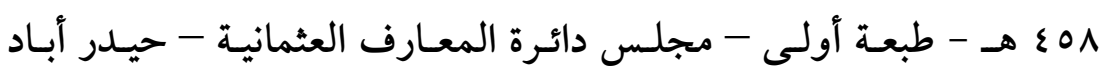

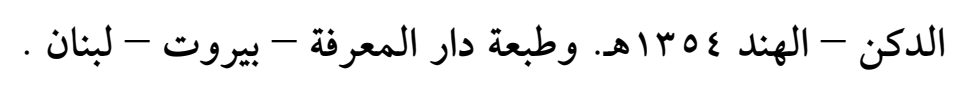

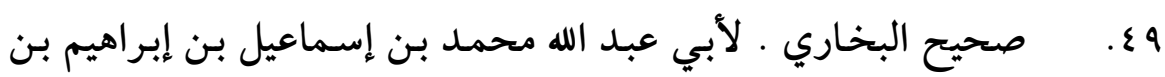

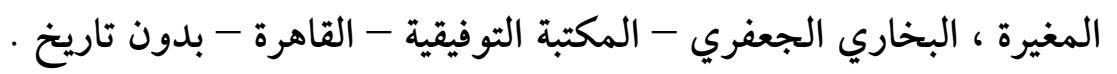

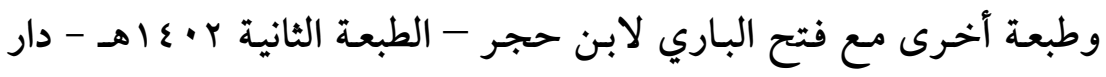

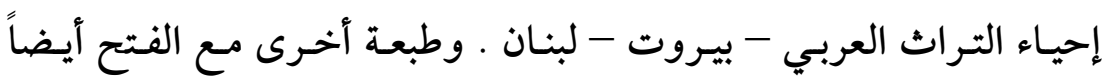

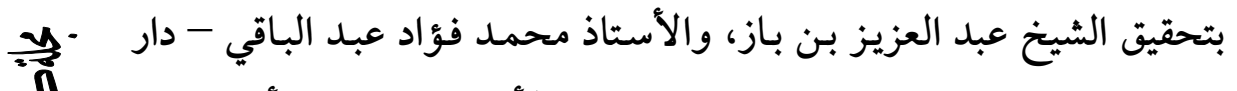

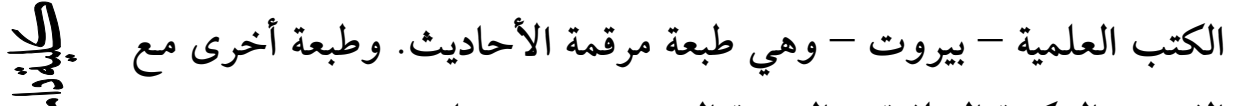

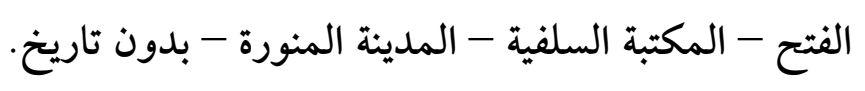

类

$\mu \cdot r$

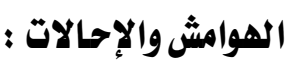

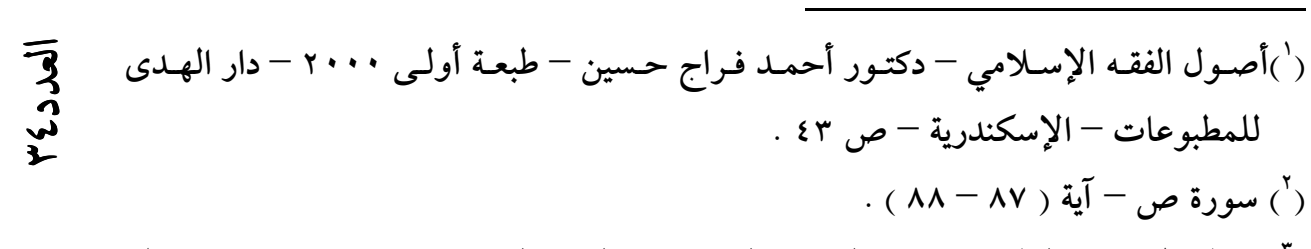

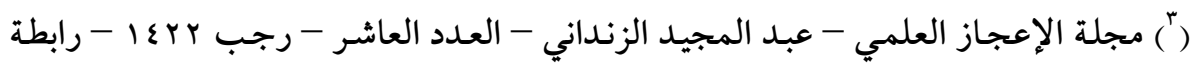

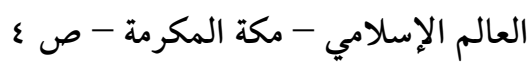

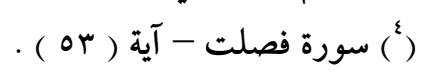

(ْ) الإعجاز العلمي في القر آن الكريم - محمد السيد أرناؤوط - مكتبة مدبولي - القاهرة -

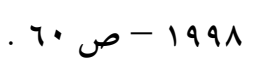

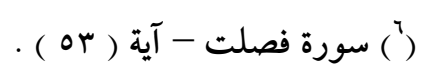

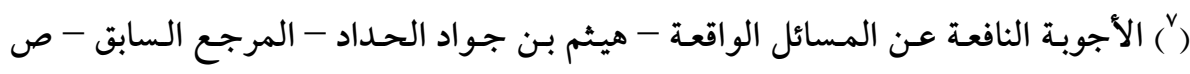

$$
\text { ro. }
$$

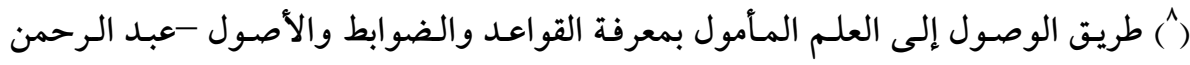

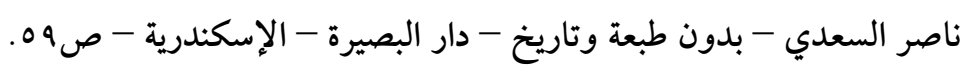


(9) المنجد في اللغة والإعلام، المطبعة الكاثوليكية ودار المشرق، بيروت، الطبعة الثامنة

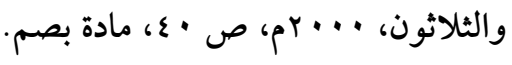

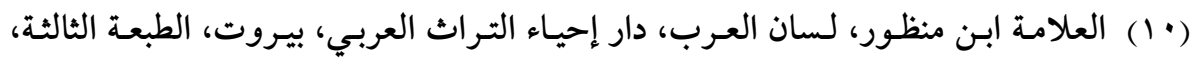

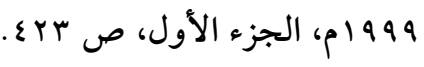

(11) سعدي أو جيب، القاموس الفقهي لغةً واصطلاحًا، دار الفكر، سوريا، الطبعة الأولى،

$$
\text { rVV ص (1991 }
$$

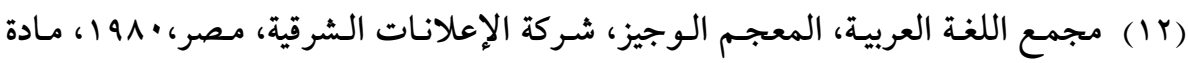

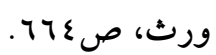

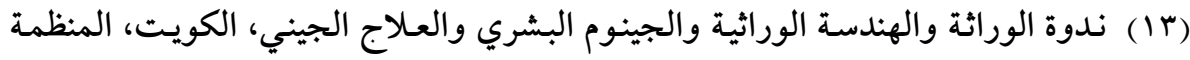

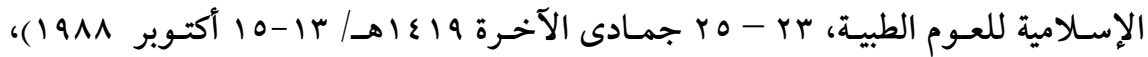

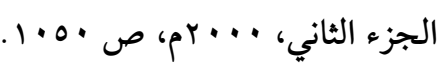

(ع ( ) انظر: القرار السابع بشأن البصمة الوراثية ومجالات الاستفادة منها، الدورة السادسة

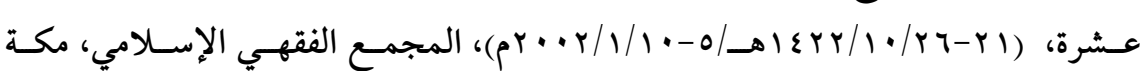

(17) دكتور أبو الوفا محمد إبراهيم، مدى حجية البصمة الوراثية في الإثبات الجنائي في

$$
\text { المكرمة. }
$$

(10) سعد الدين مسعد الهلالي، البصمة الوراثية وعلائقها الشرعية، مكتبة الكويت الوطنية،

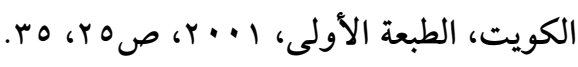

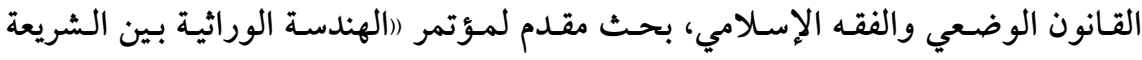

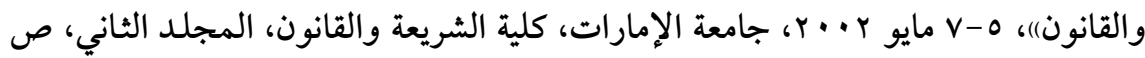

(IV) دكتور رمسيس بهنام، البوليس العلمي أو فن التحقيق، منشأة المعـارف، إسكندرية،

$$
\text { 10. 1999 } 199
$$

(1N) دكتور وهبة الزحيلي، البصمة الوراثية ومجالات الاستفادة منها، بحث مقدم إلى الدورة

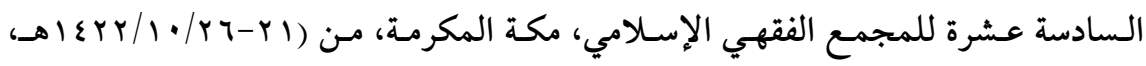

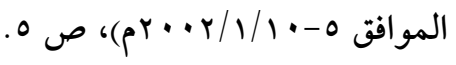

(9 19) دكتورة عائشة سلطان المرزوقي، إثبات النسب في ضوء المعطيات العلمية المعاصرة،

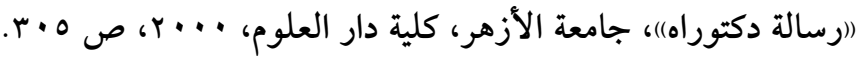




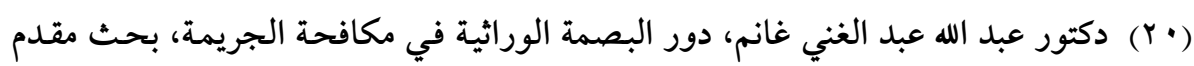

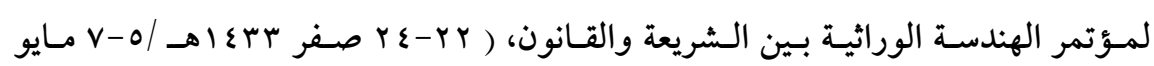

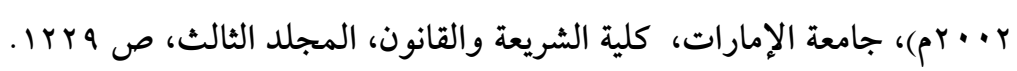

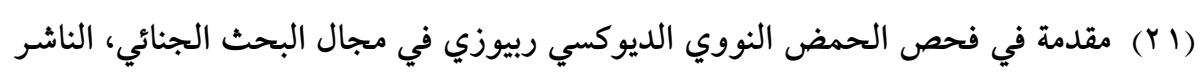

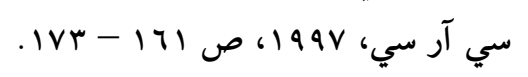

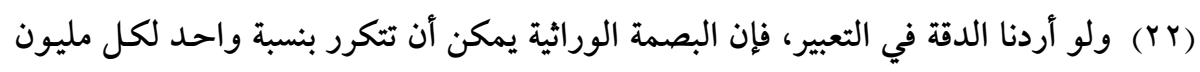

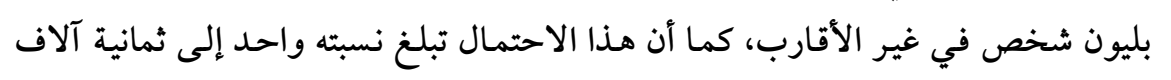

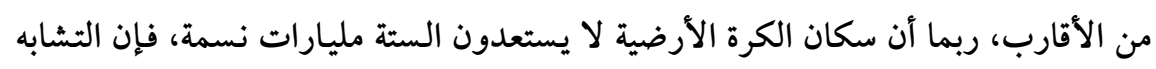

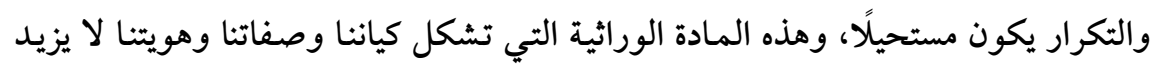

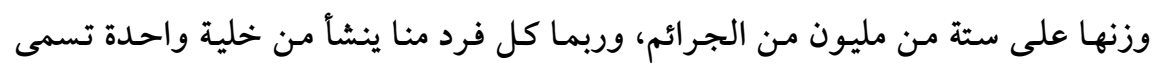

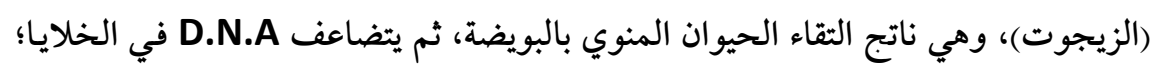

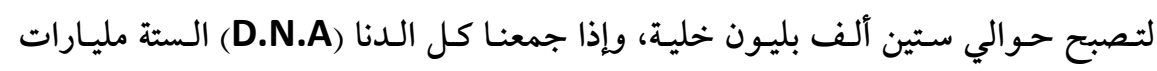

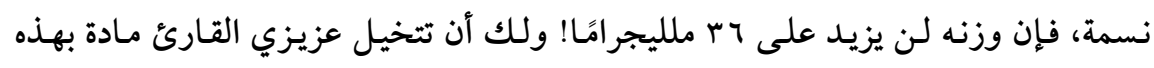

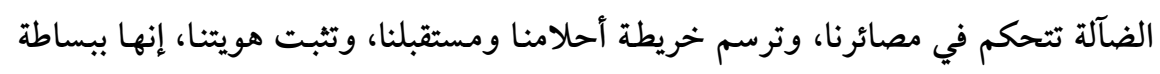

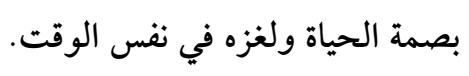

(راجع حكاية D.N.A من ملابس مونيكا الداخلية حتى شعر صدام، داخالد منتصر، مقال مأخوذ من الشبكة العالمية للمعلومات (الإنترنت).

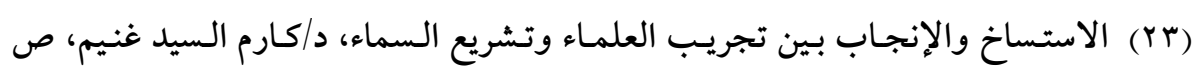

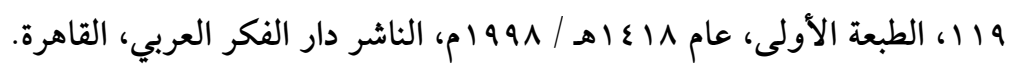

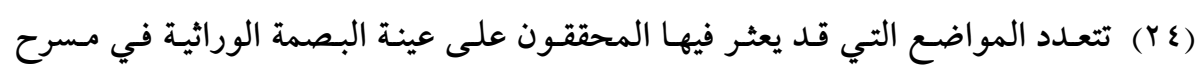

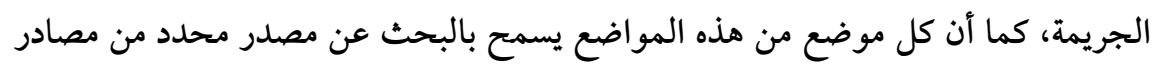

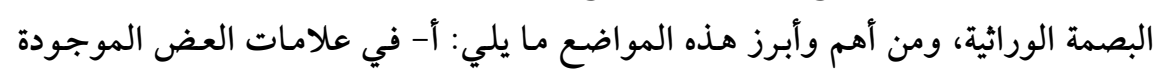

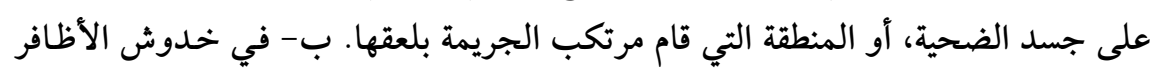

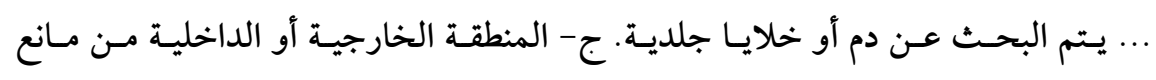

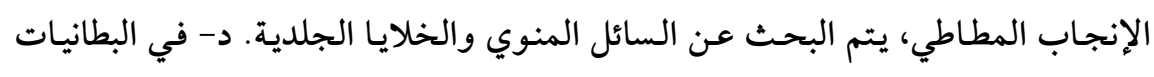

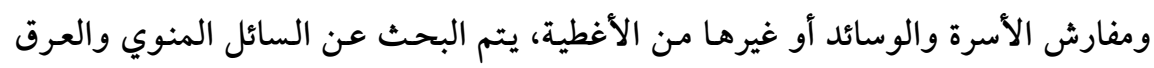

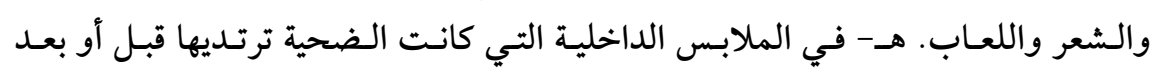

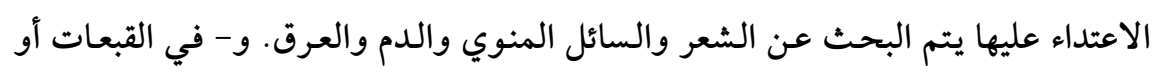


الأقنعة يتم البحـث عن الخلايـا الجلديـة والشعر أو اللعاب أو السائل المنوي. ح- في

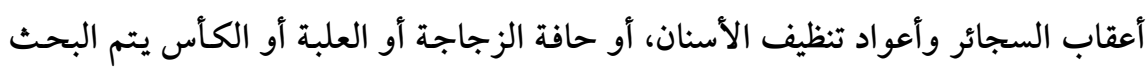

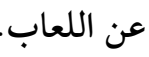

انظر: استخدام البصمة الوراثية في المجال الجنائي: د/معتز محيي عبد الحميد، مقال مأخوذ من الشبكة العالمية للمعلومات (الإنترنت).

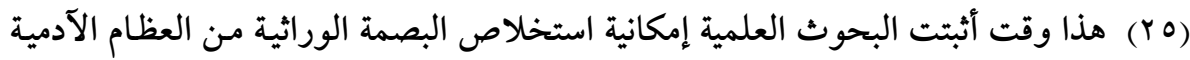

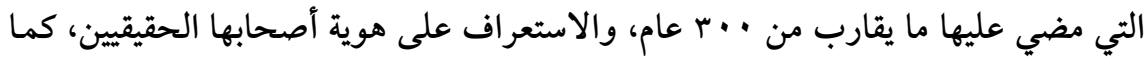

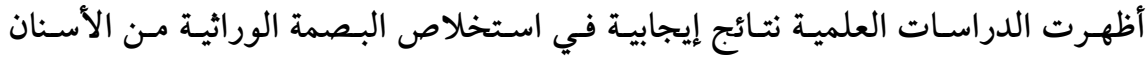

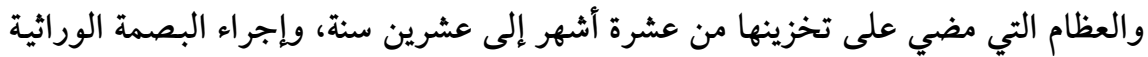

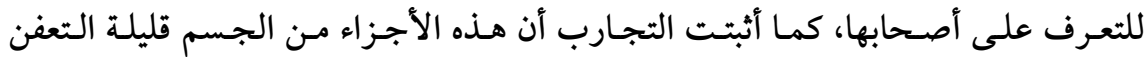
والتحلل، وأكثر فائدة مـن الأنسجة والحشوات. انظر : توظيف العلوم الجنائية لخدمـة

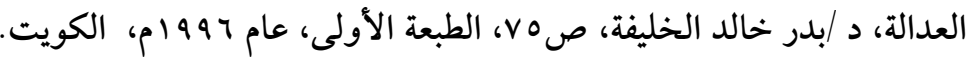

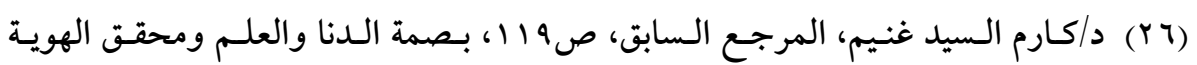

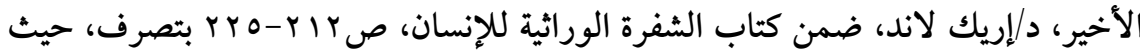
ذكر جميع خصائص البصمة الوراثية بصور متفرقة. (YV)

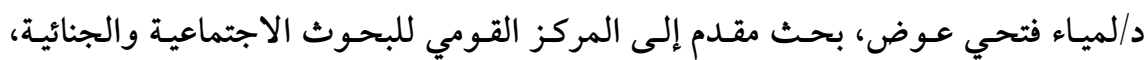

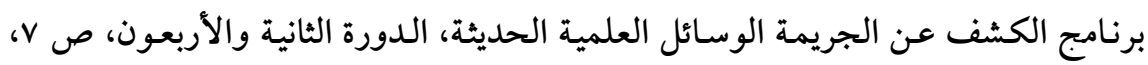

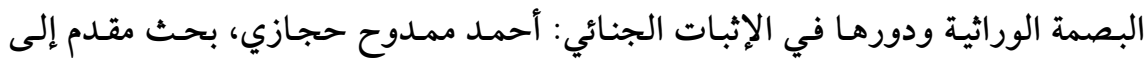

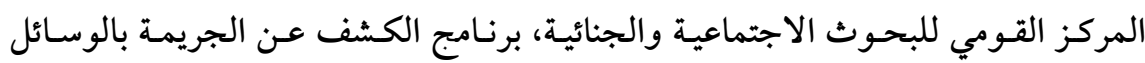

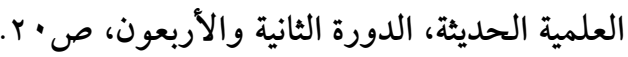
(YA)

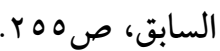
(Y (Y) هـا ونظرًا لأهمية عينات الحامض النوري في الكشف عن المجرمين؛ فإن عملية جمعها وحفظها تعتبر مهمة للغاية، وذلك منعًا لإفساد الأدلة أو تلويثها.

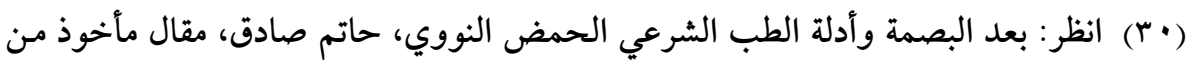


(r. البصمة الوراثية كثف الحقائق أم بداية المأزق، المجلة الطبية، تكنولوجيا الطب، مقال مأخوذ من الشبكة العالمية للمعلومات (الإنترنت).

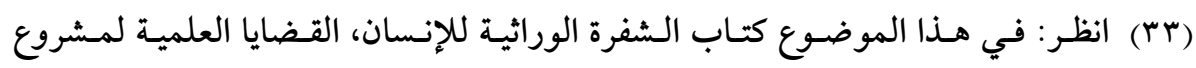

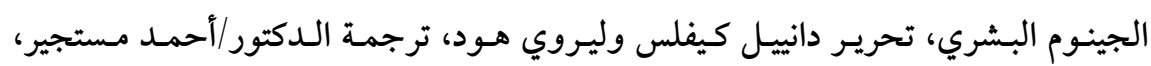

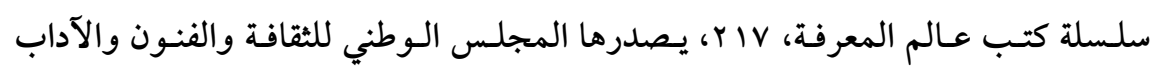

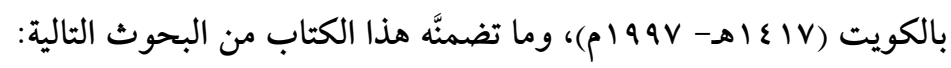

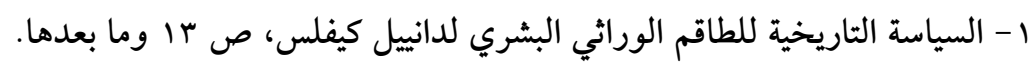

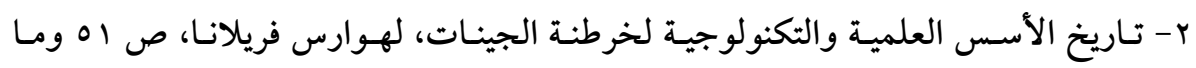
ب- رؤيـة للكـأس العلميـة والتكنولوجيـة لخرطنة الجينـات، لهـوارس فريلانـد، ص اه ومـا بعدها. بعدها. ع - طب أسامه الدنا، الوقاية والعلاج، لتوماس كاسكي، ص r بrا وما بعدها.

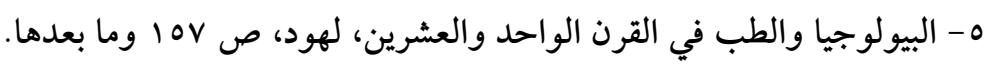

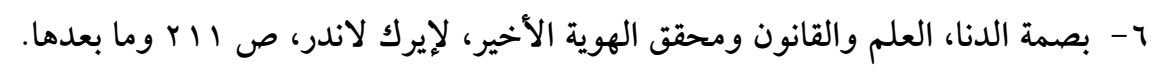

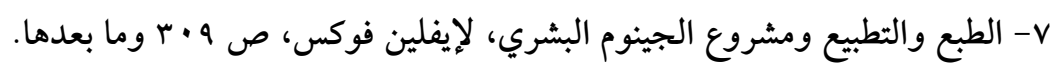
$\overline{3}$
3
3
3

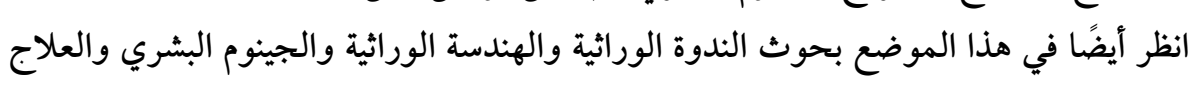

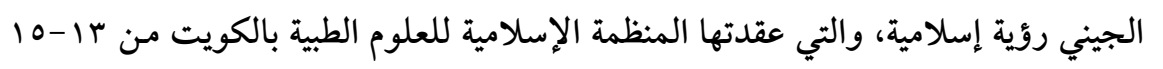

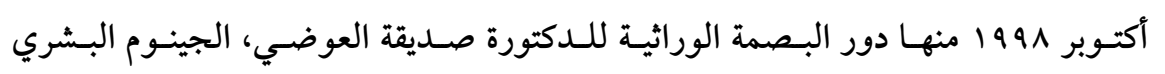

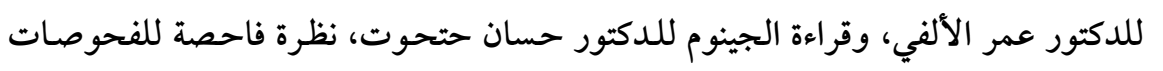

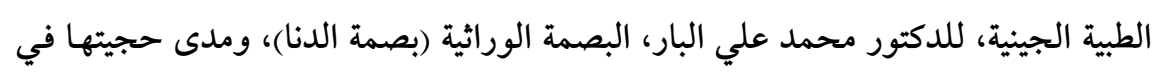
إثبات البنوة للدكتور سفيان محمد العسولي.

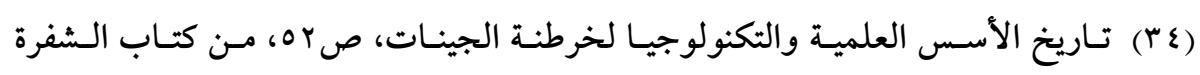
الوراثية للإنسان.

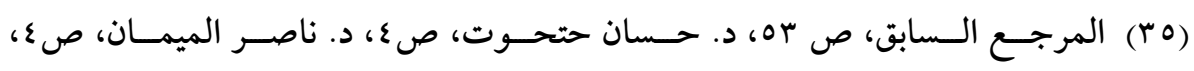

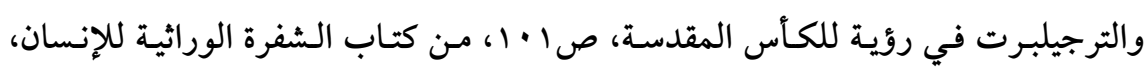

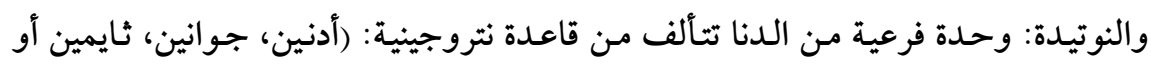

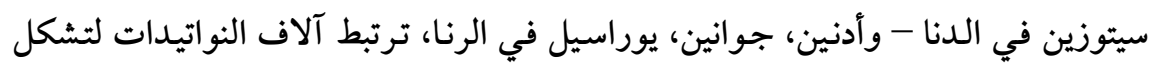

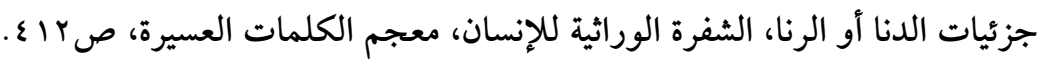


(Tr) الرفليب هو تباين طول شظايا التحديد. وهذا التباين يظهر بين الأفراد في حجم شظايا

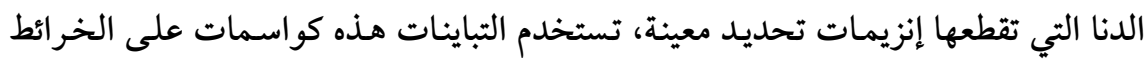

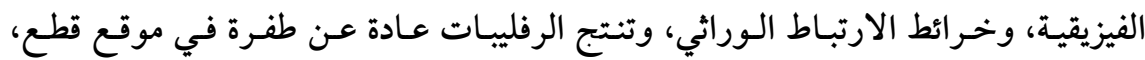

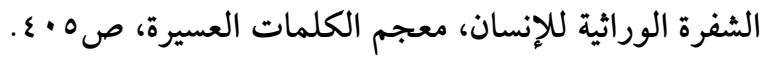

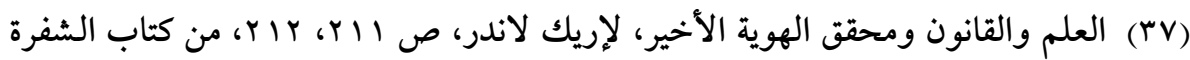
الوراثية للإنسان.

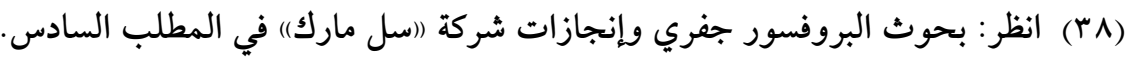

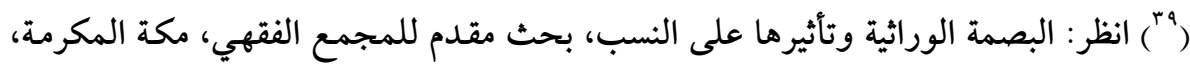

الدورة السادسة عشرة، صه وما بعدها، تقنيات البصمة الوراثية، لعبد القادر الخياط.

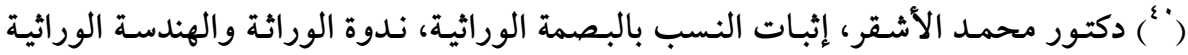

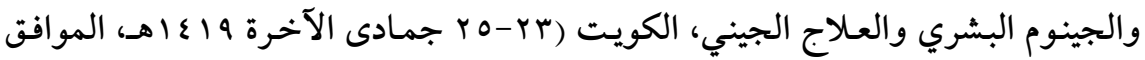

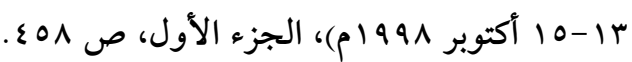

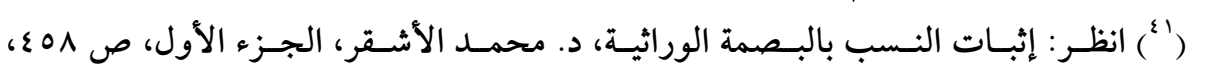
والبصمة الوراثيـة مـن منظور الفــه الإسلامي، علي القـره داغي، الدورة السادسة عشرة

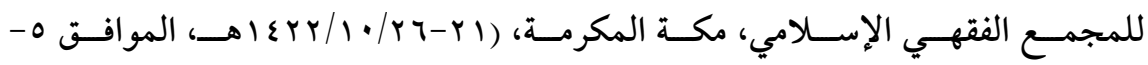
• •

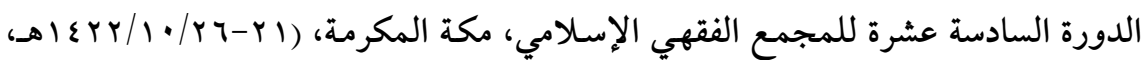

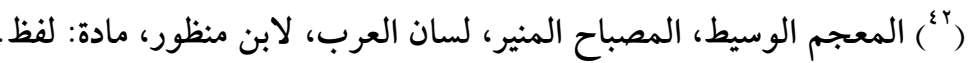

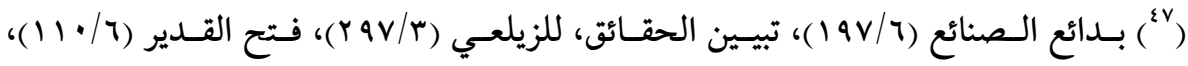

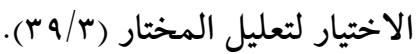

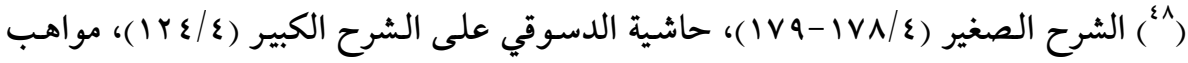

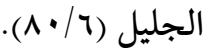

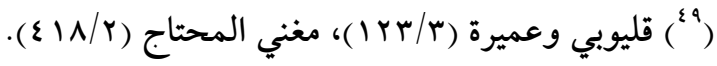




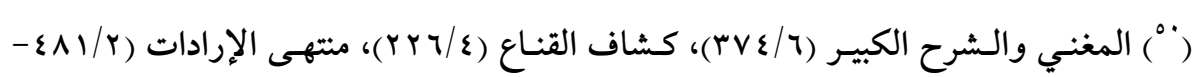

. (\&AY

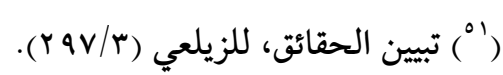

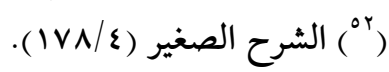

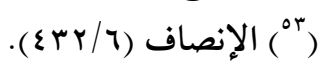

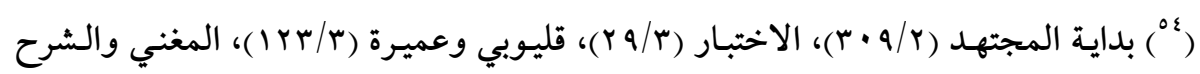

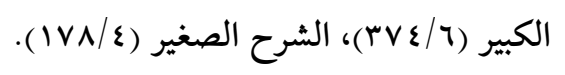

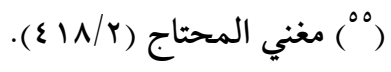

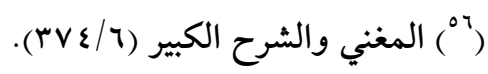

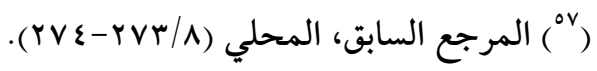

势

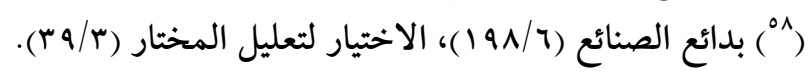

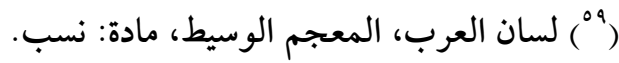

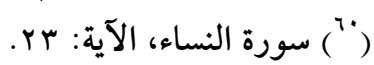

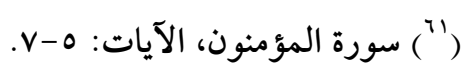

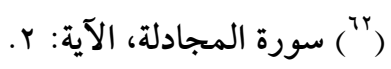

$\overline{3}$
3
3
1

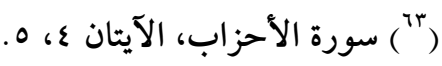

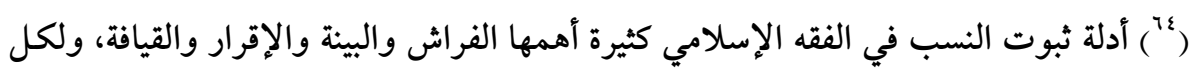

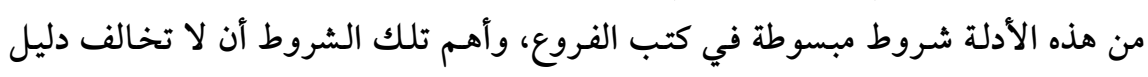

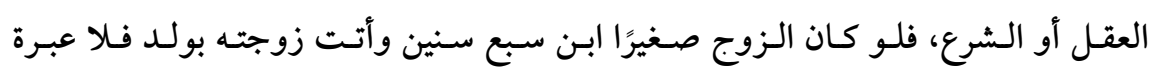

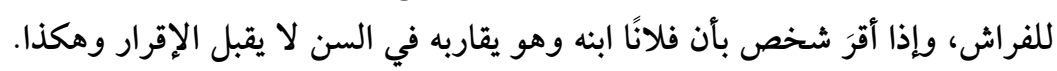

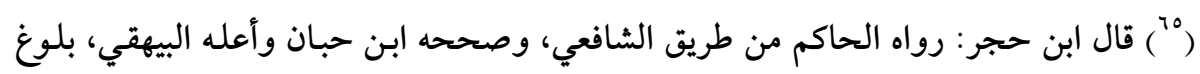

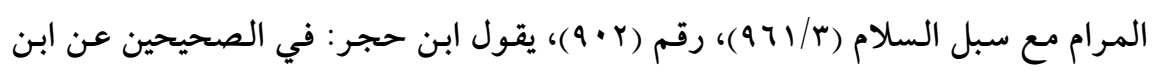

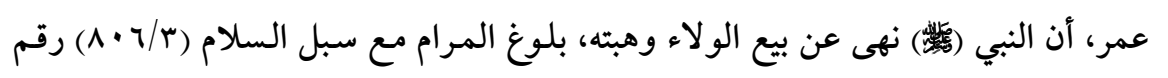

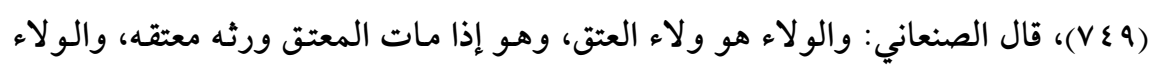

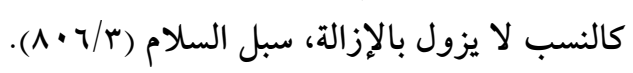

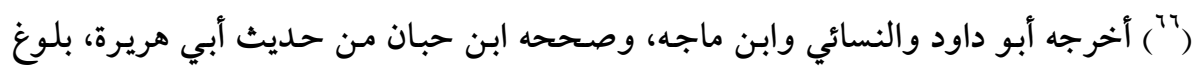

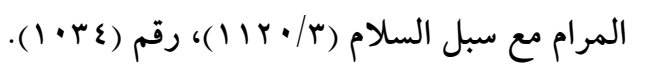




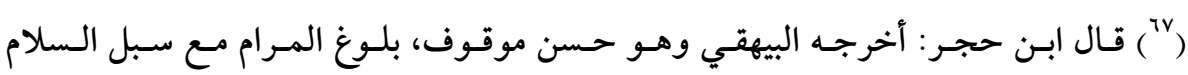

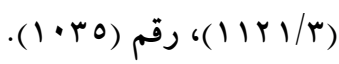

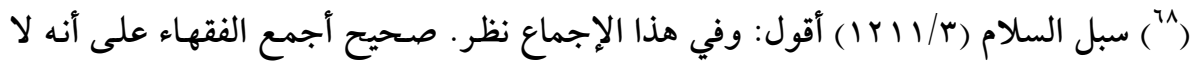

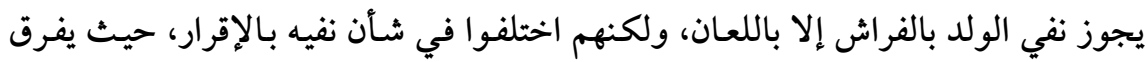

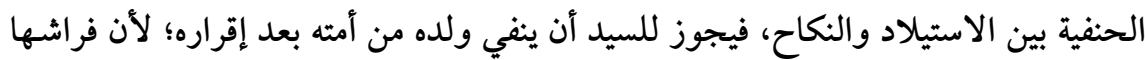

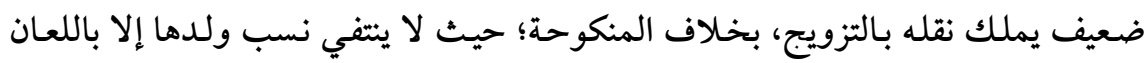

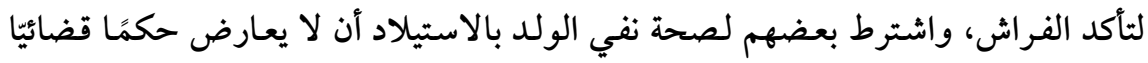

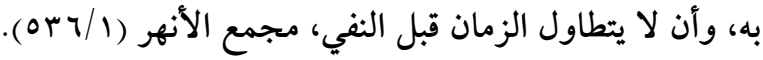

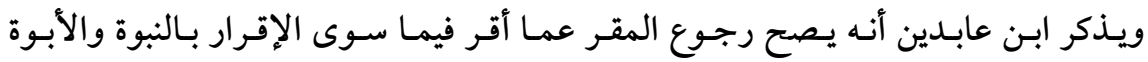

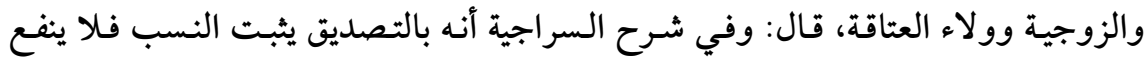

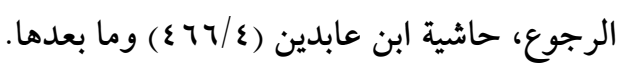

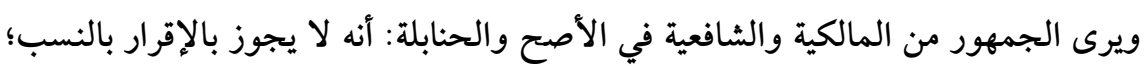

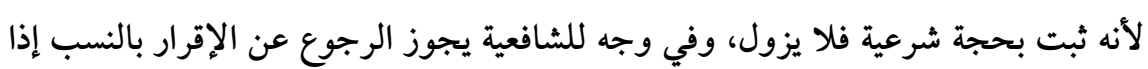

$$
\text { وافقه المقر له. }
$$

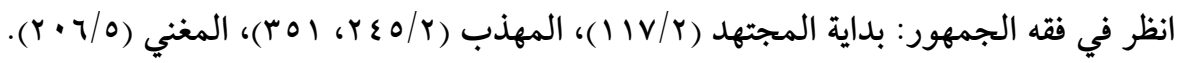

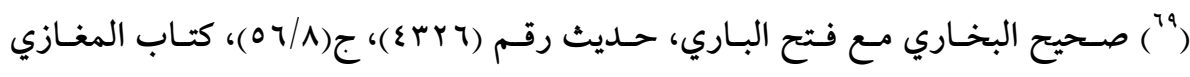

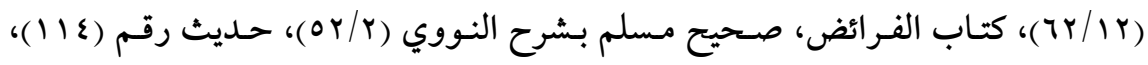

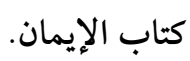

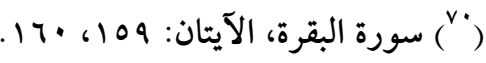

$$
\begin{aligned}
& \text { (") سورة النساء، الآية: ع ع (1) }
\end{aligned}
$$

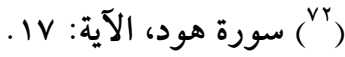

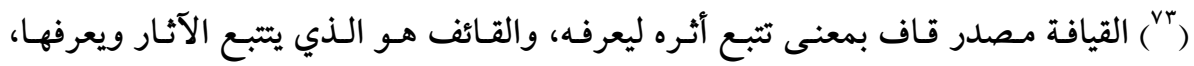

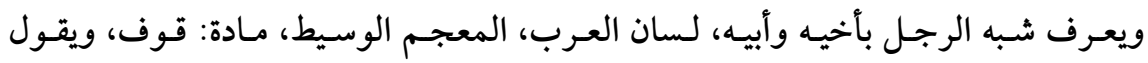

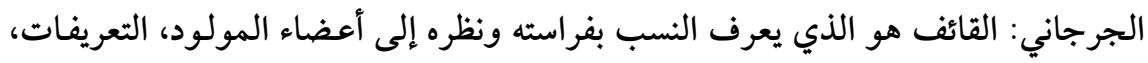

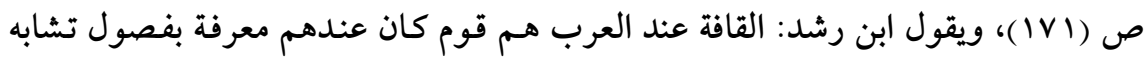

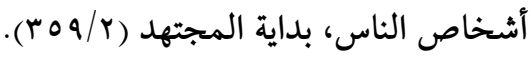

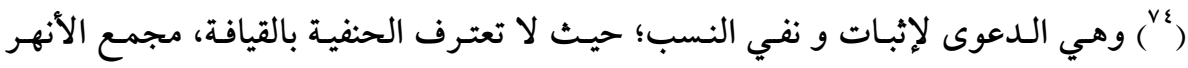

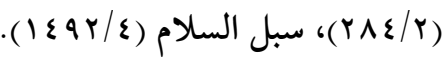




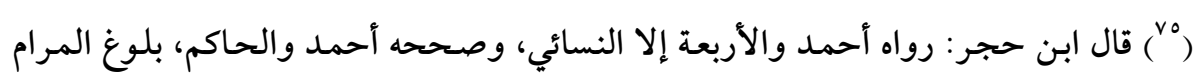

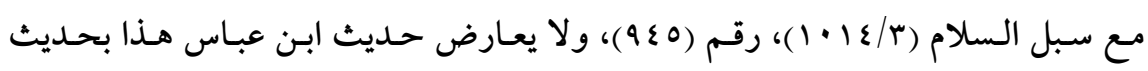

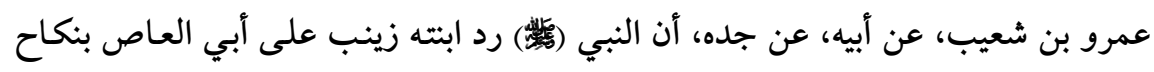

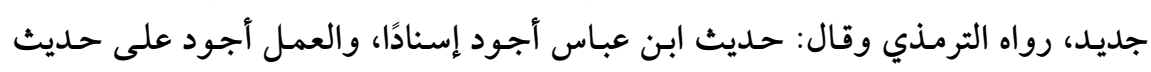

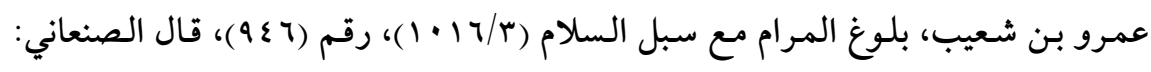

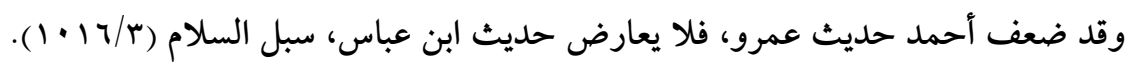

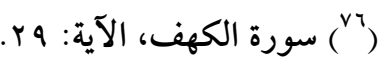

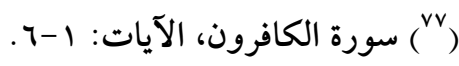

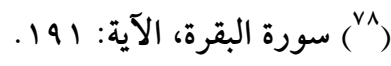

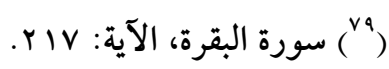

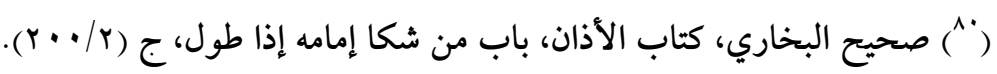
(

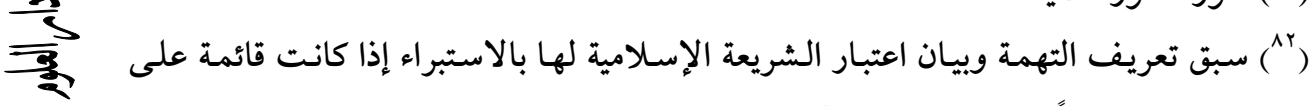

وجه، راجع سابقًا موقف الشريعة الإسلامية من استبراء التهمة بالجريمة.

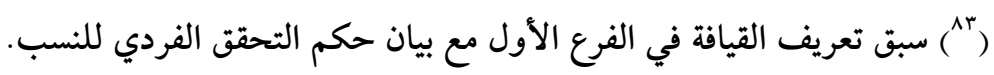

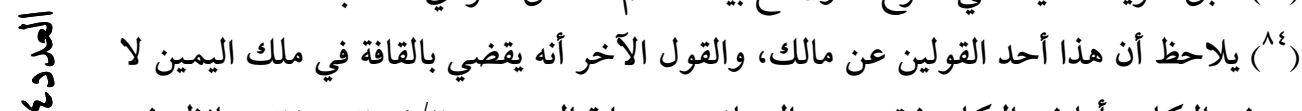

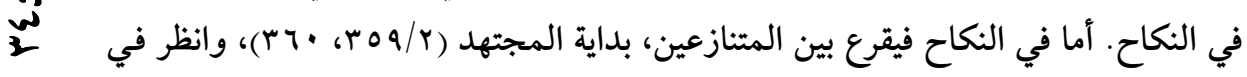

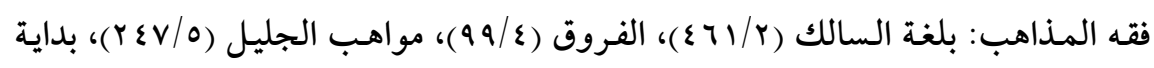

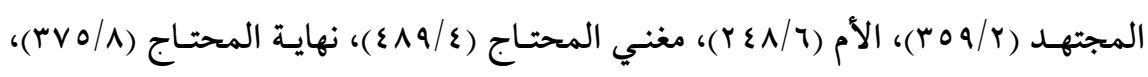

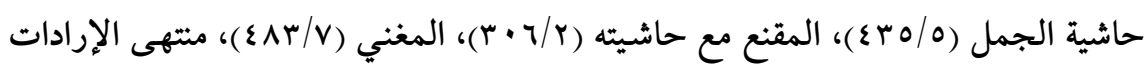

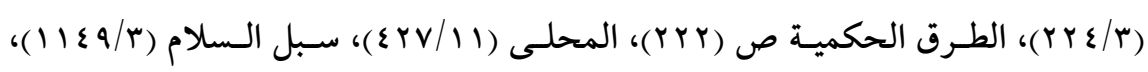
(ع (

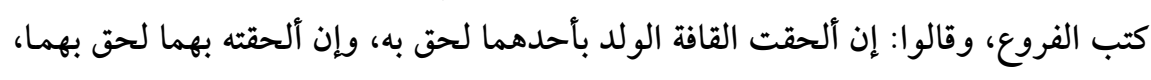

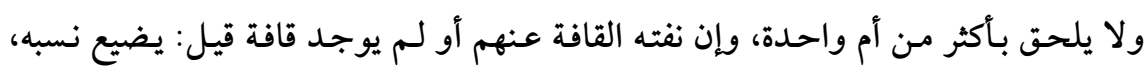

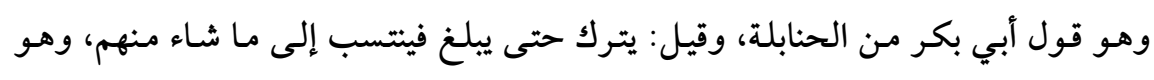

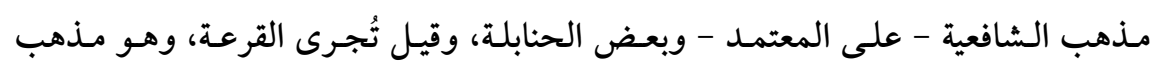

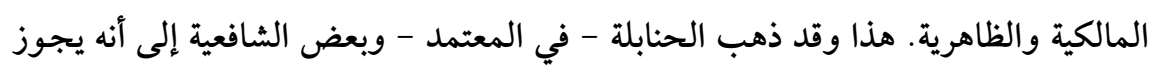




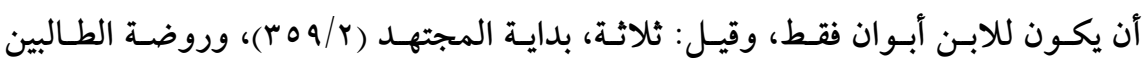

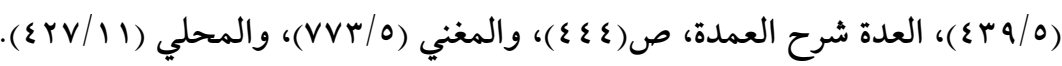

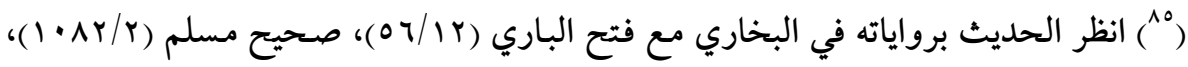

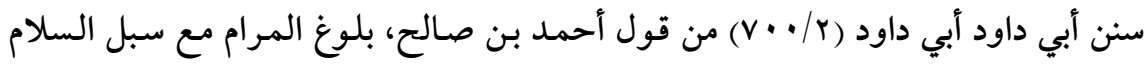

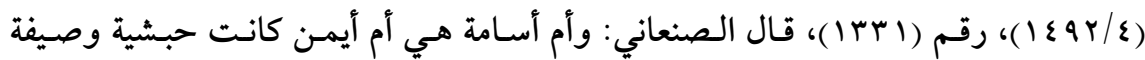

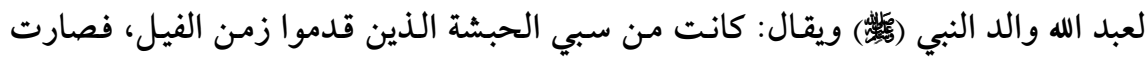

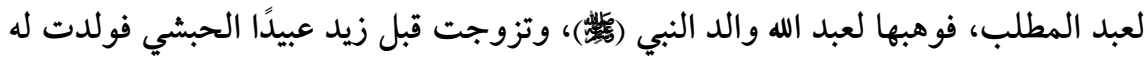

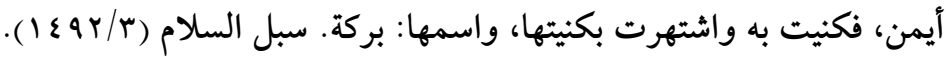

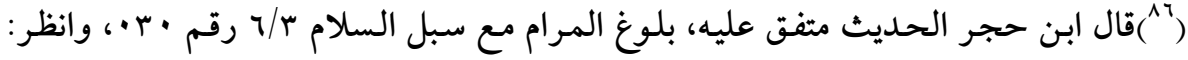

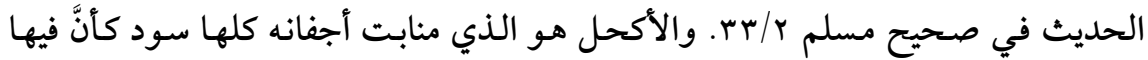

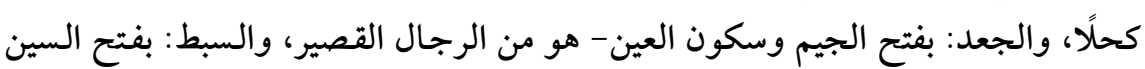

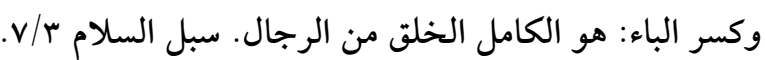

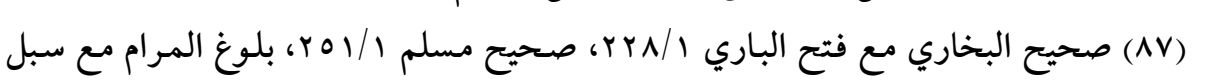

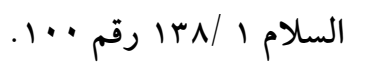

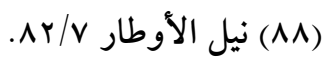

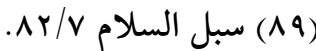

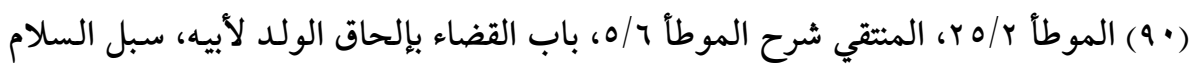

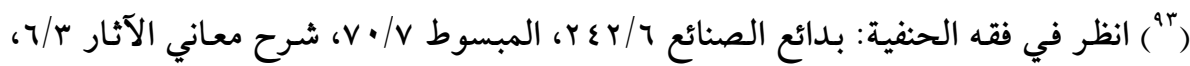

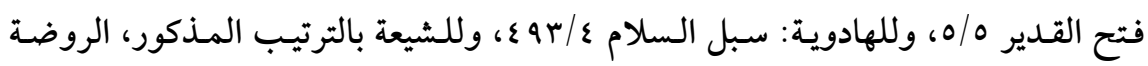

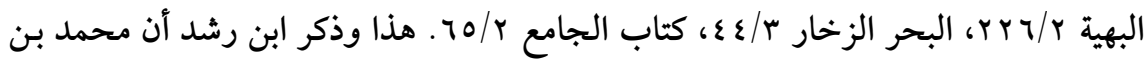

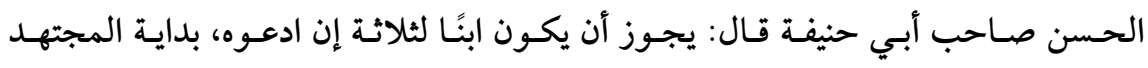

("9) روي الحديث في الصحيحين عن عائشة وأبي هريرة، وعن ابن مسعود عند النسائي،

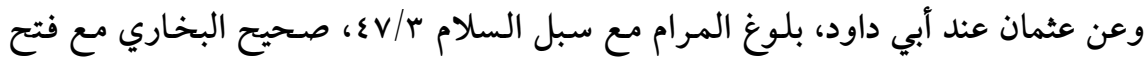

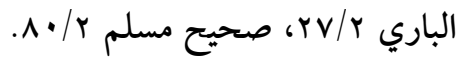


(10) روى الحديث في الصحيحين عن عائشة وعن أبي هريرة، وعن ابن مسعود عند النسائي،

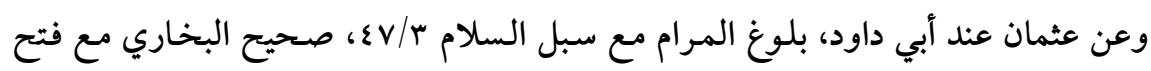

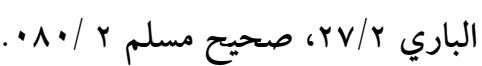

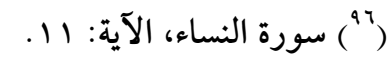

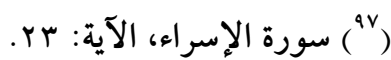

(1) قال ابن رشد بعد أن حكى قول البعض من الجمهور: إنه يجوز أن أن يكون للابن الواحد

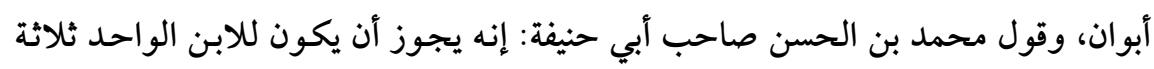

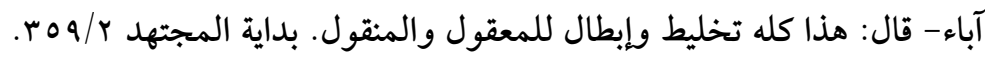

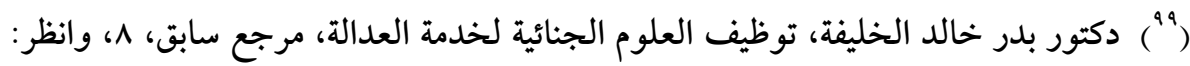

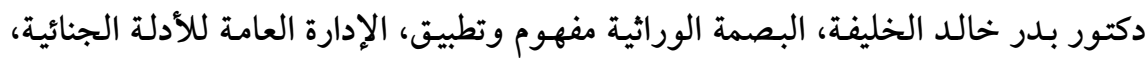

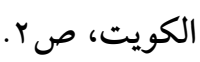

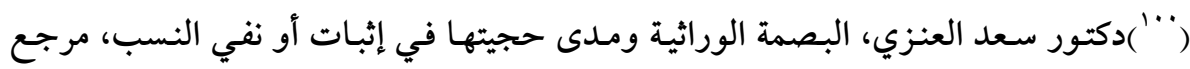

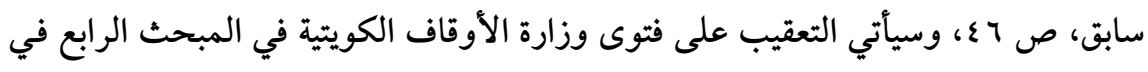
rir القضاء الأردني.

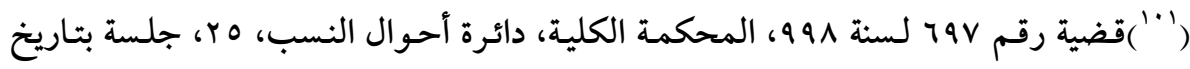
亨 ع ب/9 9، الكويت.

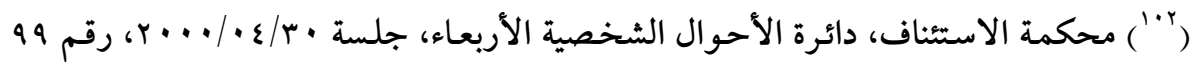

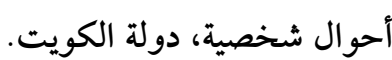

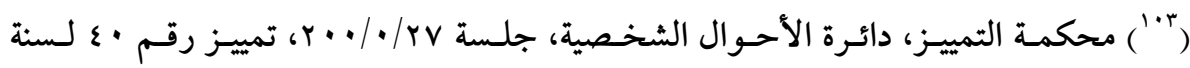

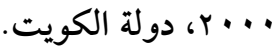

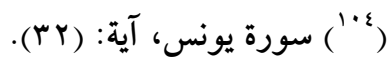

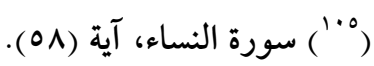

